*akls View/Frint Document Cover Sheet tow

This document was retrieved from the Boeing ISEARCH System.

Accession \#: D196050277

Document \#: SD-TP-SEP-035

Title/Desc:

SAFETY EVALUATION FOR PACKAGING FOR ONSITE

TRANSFER OF PLUTONIUM RECYCLE TEST REACTOR ION EXCHANGE COLUMNS 


\begin{tabular}{|c|c|c|c|c|c|c|}
\hline \multirow{3}{*}{$\begin{array}{l}\text { 2. ECN Category } \\
\text { (mark one) } \\
\text { Supplenental } \\
\text { Direct Revision } \\
\text { Chainge ECN } \\
\text { Tellporary } \\
\text { Standby } \\
\text { Supersedure } \\
\text { Cancel/Noid }\end{array}$} & \multirow{3}{*}{$\begin{array}{r}{[]} \\
{[x]} \\
{[]} \\
{[]} \\
{[]} \\
0] \\
{[]}\end{array}$} & \multicolumn{2}{|c|}{$\begin{array}{l}\text { 3. Originator's Name, Organization, MSIN, } \\
\text { and Telephone No. } \\
\text { ME Burns ide } / 84300 / 62-02 / \\
376-7858\end{array}$} & \multicolumn{2}{|c|}{$\begin{array}{l}\text { 3a. Use Required? } \\
{[] \text { Yes }[X] \text { Ho }}\end{array}$} & $\begin{array}{l}\text { 4. Date } \\
09-11-95\end{array}$ \\
\hline & & \multicolumn{2}{|c|}{$\begin{array}{l}\text { 5. Project Title/No./Nork Order No. } \\
\text { SEP for Onsite Transfer of } \\
\text { Plutonium Recycle Test Reactor } \\
\text { Ion Exchange Columns }\end{array}$} & \multicolumn{2}{|c|}{$\begin{array}{l}\text { 6. Bldg./Sys./Fac. No. } \\
\text { 309 Building Ion } \\
\text { Exchange Columns }\end{array}$} & $\begin{array}{l}\text { 7. Approval Designator } \\
\text { SQ }\end{array}$ \\
\hline & & \multicolumn{2}{|c|}{$\begin{array}{l}\text { 8. Document Numbers Changed by this ECN } \\
\text { (includes sheet no. and rev.) } \\
\text { WHC-SD-TP-SEP-035, Rev. } 10\end{array}$} & \multicolumn{2}{|c|}{$\begin{array}{l}\text { 9. Related ECN No(s). } \\
\text { NA }\end{array}$} & 10. Related PO No. \\
\hline \multirow{2}{*}{\multicolumn{2}{|c|}{$\begin{array}{l}\text { 11a. Modification Work } \\
\text { [] Yes (fill out Blk. } \\
\text { 11b) } \\
\text { [X] No (MA Blks. 11b, } \\
11 c, 11 d)\end{array}$}} & \multirow[t]{2}{*}{$\begin{array}{l}\text { 11b. York Package } \\
\text { No. } \\
\text { NA }\end{array}$} & \multirow{2}{*}{\multicolumn{2}{|c|}{$\begin{array}{l}\text { 11c. Modification Work Complete } \\
\text { NA }\end{array}$}} & \multicolumn{2}{|c|}{$\begin{array}{l}\text { 11d. Restored to Original Condi- } \\
\text { tion (Temp. or Standby ECN only) } \\
\text { NA }\end{array}$} \\
\hline & & & & & $\operatorname{cog} . E$ & neer $\mathbf{s i}$ \\
\hline
\end{tabular}

12. Description of Change

This ECN is a result of filling the subject boxes with excessive grout. The resulting deflection near the lid to box mating surfaces prevents closure using the 7 id.

Correcting the excessive grout condition is not ALARA because of the exposure (dose) to personnel involved in correcting the condition. Therefore, the purpose of this ECN is to document the safety and structural integrity of the over weight boxes containing ion exchange columns and grout when shipped without the box 1 ids.

See pages 3 through 7 of this ECN for specific changes (changes 1. through 37.) to WHC-SD-TP-SEP-035.

13a. Justification (mark one)

Criteria Change [] Design Improvenent [] Environmental [] Facility Deactivation As-Found [X] Facilitate Const [] Const. Error/Omission [] Design Error/Onission

13b. Justification Details

This ECN is justified because correcting the excessive grout condition is not ALARA based on the exposure (dose) to personnel involved in correction.

This ECN confirms that the new containment boundary (the grout, the top, sides, and bottom of the box) maintains sufficient structural integrity to allow shipment of the over weight boxes without the box lids. The boxes only require plastic wrap over the exposed grout to keep the grout from contact with adverse weather conditions.

Cont inued on page 7.

14. Distribution (include name, MSIN, and no. of copies)

M. E. Burnside G2-02 S. S. Shiraga

J. G. Field G2-02

R. J. Smith

G2-02

J. R. Green

WHC-SD-TP-SEP-035 File

P. W. Griffin

$\times 5-53$

C. R. Hoover

H4-16

Central Files

G2-02

G2-02

G2-02

A3-88

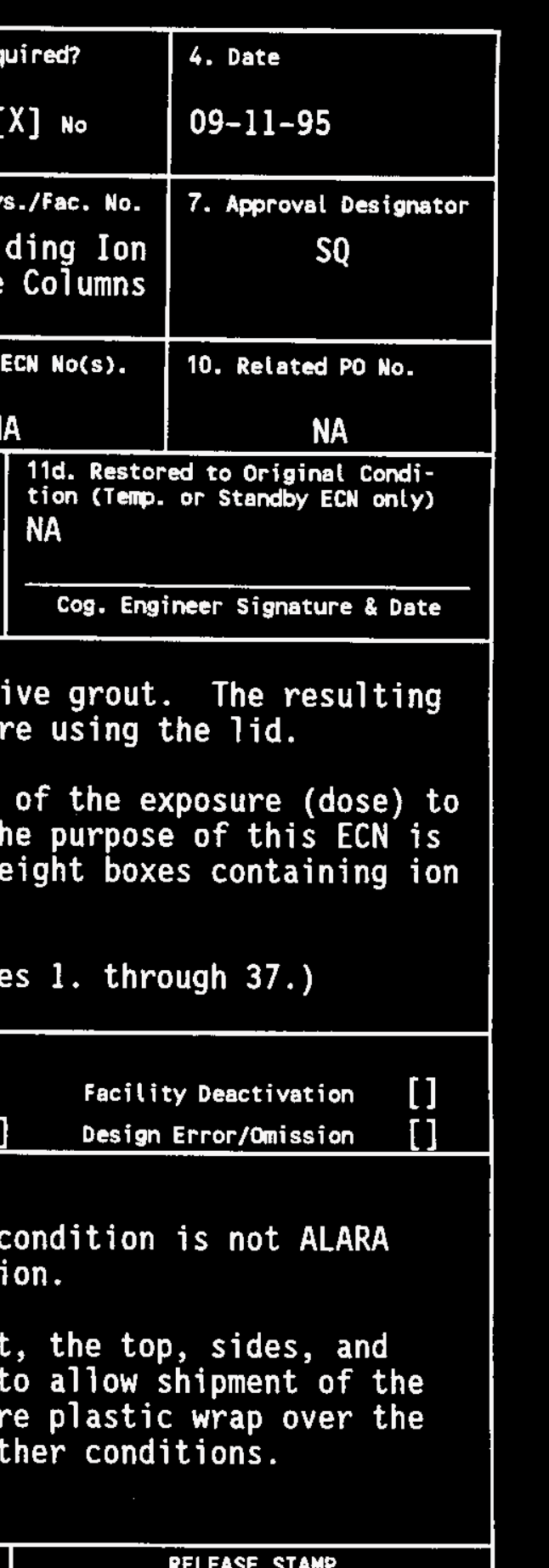

D. W. McNally G2-02

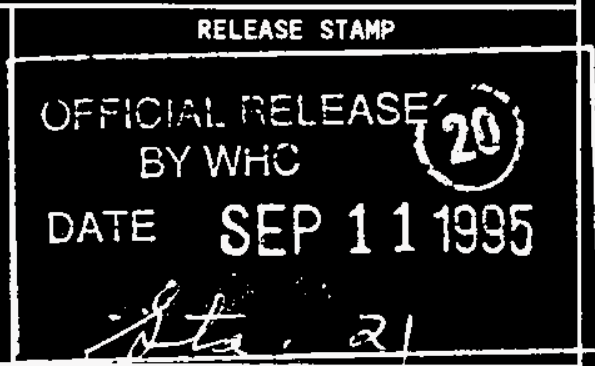




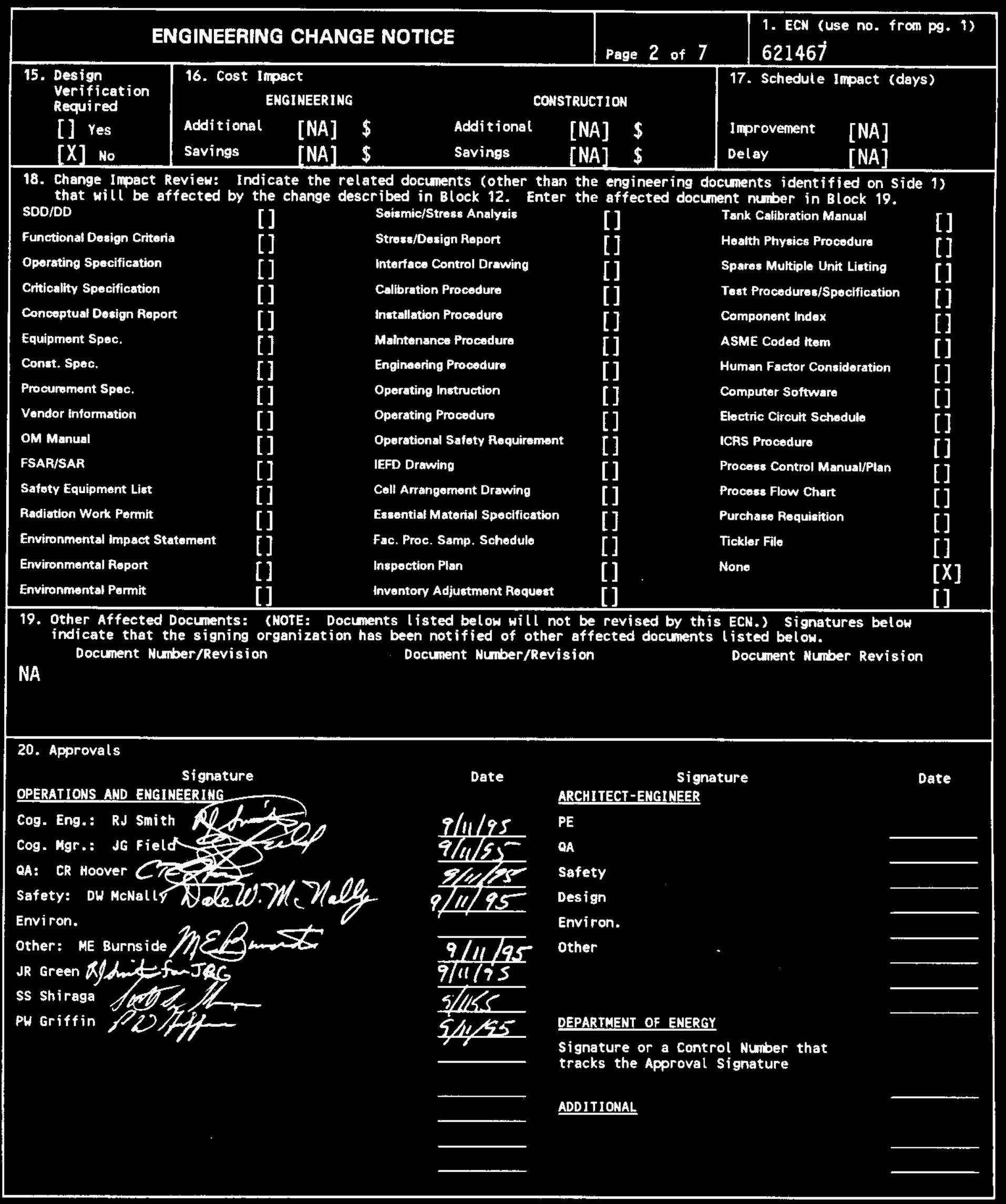




\section{Description of Change (continued)}

The following are specific changes to WHC-SD-TP-SEP-035 as indicated on page 1, section 12. of this ECN:

Change 1. Part A, Section 1.1, paragraph 4:

Change to shielding evaluation.

Change 2. Part A, Section 1.1, paragraph 3, last sentence add:

Because deflection of the boxes near the flange of the 1 id, and excess grout, will require each box containing grout to be shipped without a 1id. The exposed grout in these boxes will be covered with plastic as a precaution to keep the grout from being exposed to adverse weather conditions.

Change 3. Part A, Section 1.1, paragraph 5, change to read as follows:

Based on the overweight characteristics of the packaged columns, and because the lids will be left off of the Category $3 \mathrm{LLW}$ boxes, the section of the road on which the shipment will be transported that normally is open to public access shall be closed to exclude the public and nonessential workers from access to the shipment.

Change 4. Part A, Section 2.5, change to the following:

The containment boundary for the category $1 \mathrm{LLW}$ box is considered to be the top, bottom, and sides of the box, the neoprene gasket, and the $1 \mathrm{id}$. The containment boundary for the two (2) category 3 LLW boxes is considered to be the bottom and sides of the box, and the top layer of grout because each box will be shipped without a 1 id.

Change 5. Part A, Section 2.11, change to the following:

No sophisticated operations are required to close the box containing category 1 LLW. Box closure operations for the box containing category 1 LLW requires inserting the payload in the box then securing the gasket and 1 id.

Box closure operations for the two (2) boxes containing the category 3 LLW includes inserting the payload in the box then covering the top of the box with plastic.

Change 6. Part A, Section 4.2, last sentence, change to the following:

Bracing will include I beams chained to the trailer, with one I beam on all four 1 inear sides of the boxes.

Change 7. Part A, Section 4.3, bullet 1, change to the following:

The boxes exceed the manufacturer's maximum gross weight 1 imit of $70001 \mathrm{bs}$. In addition, the boxes containing category 3 LLW will not have 1 ids attached to the boxes. Therefore, the section of the road on which the shipment will be transported that is normally open to the public shall be closed to the public and non-essential workers. 
Change 8. Part A, Section 4.3, bullet 6 , change to the following:

The category 1 LLW box will be visually inspected to ensure that containment surfaces and the lid sealing interface have no visible breaches. The category 3 LLW boxes will be visually inspected to ensure that the exposed grout is covered with plastic, and that there are no visible breaches in the box or plastic cover.

Change 9. Part A, Section 4.3, bullet 13, first sentence, change the following:

- Change "shielding calculation" to "dose rate readings"

- Change $1.64 \mathrm{rem} / \mathrm{hr}$ to $400 \mathrm{mRem} / \mathrm{hr}$.

- Delete "and $99 \mathrm{mRem} / \mathrm{hr} 1$ meter from the packages."

Change 10. Part A, Section 4.3, bullet 13:

Delete last sentence

Change 11. Part A, Section 4.3, last bullet, change to the following:

The metal boxes tied down to the trailer will be handled as a wide load and as an over weight load. Therefore, the load will be specially permitted for both wide load and over weight conditions.

Change 12. Part A, Section 6.2, 4., change to the following:

Follow the manufacturer's closure instructions (as applicable) when sealing the category 1 LLW box. Ensure that the exposed grout in the category 3 LLW boxes is covered with plastic.

Change 13. Part A, Section 6.2, 5., change to the following:

A tamper indicating device is not needed because the payload is either enveloped in Pyro foam (category 1 LLW) or enveloped in grout (category 3 LLW).

Change 14. Part A, Section 7.1, bullet 3 , change to the following:

Verify that the category $1 \mathrm{LLW}$ box packaging closure device, including any required gasket, is properly installed, secured, and free of defects in accordance with 49 CFR $173.475(\mathrm{e})$. Verify that the category 3 LLW boxes have exposed grout covered with plastic in accordance with the requirements of this SEP.

Change 15. Part A, Section 7.1, bullet 4, add to the end of the sentence: and in accordance with the requirements of this SEP.

Change 16. Part A, Section 7.1, bullet 5, add to the end of the sentence: and in accordance with the requirements of this SEP. 
Change 17. Part B, Section 1.1, second paragraph, change to read as follows:

The primary conditions addressed in this SEP are the following:

- The over-weight condition of the boxes as a result of filling void spaces with Pyro foam and grout.

- The lids will not be secured to the category 3 LLW boxes during transportation.

- The dose rates exceed DOT limits and Hanford Site Radiological Control Limits.

The excessive weight condition, and category 3 LLW box 1 id removal, are both evaluated in Part B, Sections 3.0 and $\mathbf{5 . 0}$ of this SEP. The dose rate conditions are addressed in Part B, Section 4.0 of this SEP.

Change 18. Part B, Section 3.3, first and second paragraph:

Separate First and Second paragraph by adding a space between them.

Change 19. Part B, Section 3.3, paragraph 3, second sentence, change to the following:

Results of the evaluation indicate that a box filled with ion exchange columns and grout will withstand a normal-condition drop without buckling or excessive deformation (see Appendix B-1).

Change 20. Part B, Section 3.3, paragraph 5, last sentence, change to the following: However, the grout must be sufficiently cured for at least 7 days because the package does not have sufficient strength to support the load of uncured grout.

Change 21. Part B, Section 4.4, paragraph 1, first sentence and second sentence, change to the following:

Dose rates on the surface of the metal boxes were evaluated based on survey readings from the surface of each fully loaded metal box. Survey readings were evaluated against U.S. Department of Transportation (DOT) radiation level 1 imitations.

Change 22. Part B, Section 4.5, first paragraph:

Delete

Change 23. Part B, Section 4.5, paragraph 2, change to the following:

Survey readings indicate that the surface dose rate readings of the boxes exceed DOT limitations ( $400 \mathrm{mRem} / \mathrm{hr}$ at the surface of the package) prescribed in Part B, Section 4.4. Survey readings at one meter from the linear side of each box (including top and bottom) will not exceed the contact dose rate for any given side of all three boxes loaded together. 
Change 24. Part B, Section 4.5, paragraph 3, change to the following:

Attempting to shield the inner walls of the boxes or reposition the ion exchange columns in the boxes is contrary to ALARA principles. Therefore, if possible, configuring the boxes (if two or more boxes are loaded together) on the trailer used for transfer such that the lowest dose rate readings are exposed to the outside of the trailer is acceptable as an administrative control and method of shielding. No additional shielding is required regardless of box configuration on the trailer.

Change 25. Part B, Section 4.5, last paragraph:

Delete last sentence "See Appendix B-1 for shielding evaluation"

Change 26. Part B, Section 4.5, add new last paragraph:

Based on the source term in the boxes, the configuration of the ion exchange columns in the boxes (i.e., ion exchange columns, Pyro foam and miscellaneous waste; ion exchange columns and grout), the configuration of the boxes on the trailer(s), and the known dose rate readings at contact with the boxes (see Appendix B-1), no additional shielding analysis is required.

Change 27. Part B, Appendix B-1 (Shielding Evaluation):

Replace with 309 BLDG. Tank Farm map with waste box dose rate readings.

Change 28. Part B, Section 5.2.1, bullet 7, change to the following:

Containment Boundary: The containment boundary is the top (including neoprene gasket and 1id), bottom, and sides, of the box containing ion exchange columns, Pyro foam, and miscellaneous waste. The containment boundary for the boxes containing ion exchange columns and grout is the solidified grout itself (top layer) and the sides and bottom of the box. The lid (top) of these boxes are removed.

Change 29. Part B, Section 5.2.3,

Delete, re-number in sequence.

Change 30. Part B, Section 5.2.5 (new 5.2.4), add the following sentence:

There is no positive closure mechanism required for the boxes containing grout.

Change 31. Part B, Section 5.2.7

Delete.

Change 32. Part B, Section 5.3, add the following sentence:

In addition, the boxes were analyzed with the 1 id removed (see new Appendix B-2). 
Change 33. Part B, Section 5.4, paragraph 2, second sentence, change to the following:

Evaluation of the drop indicates that the box will withstand a normal-condition drop without buckling or excessive deformation, even with the lid removed from the boxes containing grout (see new Appendix B-2).

Change 34. Part B, Section 5.4, paragraph 4, last sentence, change to the following: However, the grout must be cured for at least 7 days because the package does not have sufficient strength to support the load of uncured grout.

Change 35. Part B, Appendix B-2:

Add the calculation provided by S. S. Shiraga entitled "Engineering Safety Evaluation, subject: IXC Grout Drop Loading (w/0 Lid)."

Change 36. Part B, Section 8.1, second sentence, change to the following:

Bracing will include I beams chained to the trailer, with one I beam on all four 1 inear sides of the boxes for added stability to help prevent the load from shifting forward or backward, or side to side, on the trailer during transfer.

\section{3b. Justification Details (continued)}

In addition, this ECN documents the lower dose rates determined by surveying the loaded boxes which establishes a safer condition for transport in terms of exposure, and subsequently eliminates the need for shielding analysis using a bounding case. 
THIS PAGE INTENIIONALLY LEFT BLANK 


\section{RELEASE AUTHORIZATION}

Document Number: WHC-SD-TP-SEP-035, Rev. 1

$\begin{array}{ll}\text { Safety Evaluation for Packaging for Onsite Transf } \\ \text { Document Title: } & \text { of Plutonium Recycle Test Reactor Ion Exchange }\end{array}$

Columns

Release Date: $\quad 9 / 11 / 95$

This document was reviewed following the procedures described in WHC-CM-3-4 and is:

APPROVED FOR PUBLIC RELEASE

WHC Information Release Administration Spacialist:

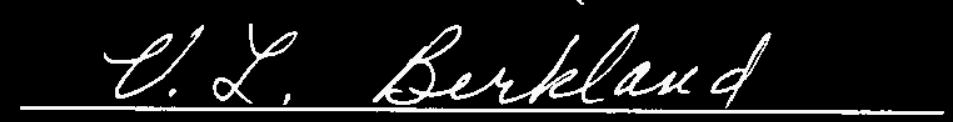

v. L. Birkland

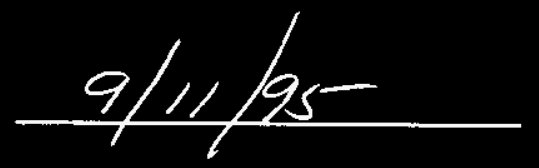

TRADEMARK DISCLAIMER. Reference here in to any specific commercial product, process, or service by trade name, trademark, manufacturer, or otherwise, does not necessarily constitute or imply its endorsement, recommendation, or favoring by the United States Government or any agency thereof or its contractors or subcontractors.

To obtain copies of this report, contact:

Westinghouse Hanford Company - Document Control Services

P.0. Box 1970, Mailstop H6-08, Richland, WA 99352

Telephone: (509) 372-2420; Fax: (509) 376-4989 
THS PAGE INTENIIONAIIY

IUEFT BLANR 


\begin{tabular}{|l|l|c|}
\hline 2. Title & 3. Number & 4. Rev Mo. \\
Safety Evaluation for Packaging for Onsite & WHC-SD-TP-SEP-035 & 1 \\
Transfer of Plutonium Recycle Test Reactor Ion \\
Exchange Columns
\end{tabular}

\section{Abstract}

The purpose of this Safety Evaluation for Packaging (SEP) is to authorize the use of three U.S. Department of Transportation (DOT) 7A, Type A metal boxes (Capita) Industries Part No. S 0600-0600-1080-0104) to package 12 Plutonium Recycle Test Reactor (PRTR) ion exchange columns as low-level waste (LLW). The packages will be transferred from the 309 Building in the 300 Area to low level waste burial in the 200 West Area.

Revision 1 of WHC-SD-TP-SEP-035 (per ECN No. 621467) documents that the boxes containing ion exchange columns and grout will maintain the payload under normal conditions of transport if transferred without the box lids.

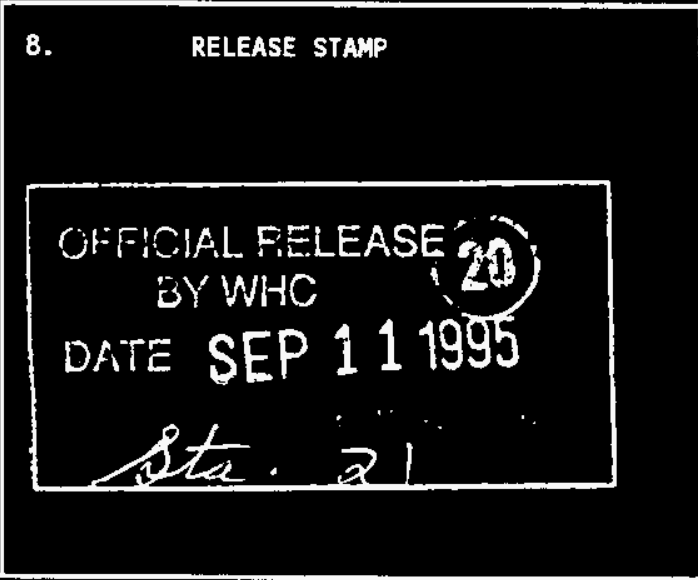


THIS PAGE INTENTIONALLY

LEFT BLANK 
(2) Title

Safety Evaluation for Packaging for Onsite Transfer of PTutonium Recycle Test Reactor Ion Exchange Columns

CHANGE CONTROL RECORD

\begin{tabular}{|c|c|c|c|}
\hline \multirow{2}{*}{ (3) Revision } & \multirow{2}{*}{ (4) Description of Change - Replace, Add, and Delete Pages } & \multicolumn{2}{|c|}{ Authorized for Release } \\
\hline & & (5) Cog. Engr. & (6) Cog. Mer. \\
\hline 0 & (7) EDT $611476,6 / 21 / 95$ & & \\
\hline 1 RS & $\begin{array}{l}\text { This revision is a result of filling the } \\
\text { subject boxes with excessive grout. This } \\
\text { documents the safety and structural } \\
\text { integrity of the overweight boxes } \\
\text { containing ion exchange columns and grout } \\
\text { when shipped without the box } 1 \text { ids. Per } \\
\text { ECN } 621467 \text {. }\end{array}$ & $\begin{array}{l}\text { RJ Smith } \\
R / S=L\end{array}$ & Field \\
\hline & & & \\
\hline & & & \\
\hline & & & \\
\hline & & & \\
\hline & & & \\
\hline & & & \\
\hline & & & \\
\hline & & & \\
\hline & & & \\
\hline & & & \\
\hline & & & \\
\hline & & & \\
\hline & & & \\
\hline & & & \\
\hline & & & \\
\hline & & & \\
\hline & & & \\
\hline & & & \\
\hline & & & \\
\hline & & & \\
\hline & & & \\
\hline & & & \\
\hline & & & \\
\hline & & & \\
\hline & & & \\
\hline & & & \\
\hline & & & \\
\hline & & & \\
\hline
\end{tabular}


THIS PAGS TNTENTIONALLY LEFT BLANK 


\section{CONTENTS}

PART A: DESCRIPTION AND OPERATIONS ............. Al-1

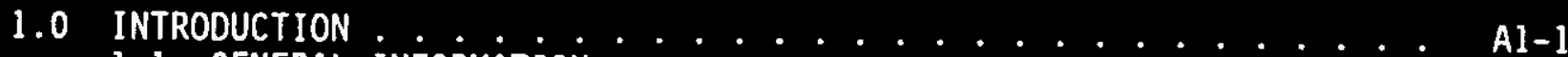

1.1 GENERAL INFORMATION ............... Al-1

1.2 SYSTEM DESCRIPTION . . . . . . . . . . . . . Al-2

2.0 PACKAGING SYSTEMS ................... A2-1

2.1 CONFIGURATIONS AND DIMENSIONS $\ldots \ldots$ A2-1

2.2 MATERIALS OF CONSTRUCTION ........... A2-1

2.3 DESIGN AND FABRICATION METHODS . . . . . . . . . A2-1

2.4 WEIGHTS AND CENTER OF GRAVITY . . . . . . . . . . . . . A2-1

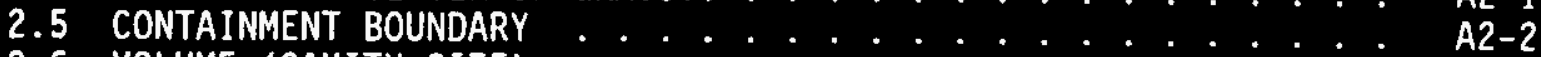

2.6 VOLUME (CAVITY SIZE) . . . . . . . . . . . A2-2

2.7 HEAT DISSIPATION . . . . . . . . . . . . . A2-2

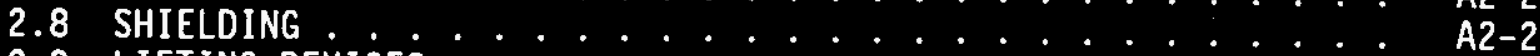

2.9 LIFTING DEVICES . . . . . . . . . . . A A2-2

2.10 TIEDOWN DEVICES $\ldots \ldots \ldots$. . . . . A2-2

2.11 OPERATIONAL FEATURES $\ldots \ldots$ A2-2

3.0 PACKAGE CONTENTS .................. . A3-1

3.1 GENERAL DESCRIPTION $\ldots \ldots$. . . .

3.2 CONTENTS RESTRICTIONS ................ A3-1

4.0 TRANSPORT SYSTEM ...................... A4-1

4.1 TRANSPORT VEHICLE . . . . . . . . . . . . . A4-1

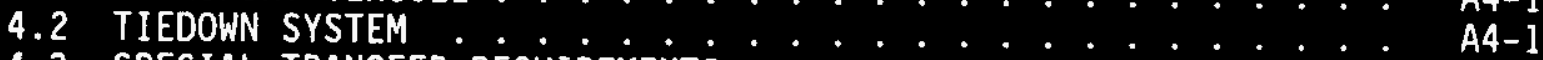

4.3 SPECIAL TRANSFER REQUIREMENTS $\ldots \ldots$

5.0 ACCEPTANCE OF PACKAgING FOR USE ............. A5-1

6.0 OPERATING REQUIREMENTS ................ A6-1

6.1 CONTENTS RESTRICTIONS .............. . . . . . . . . .

6.2 PACKAGE CLOSURE INSTRUCTION . . . . . . . . . . . A6-1

6.3 TRANSFER . . . . . . . . . . . . . . AG-2

7.0 QUALITY ASSURANCE ................... A7-1

7.1 GENERAL REQUIREMENTS ................ . . . . . . . .

7.2 SEP CONTROL SYSTEM .................. A7-1

8.0 maintenance ............................ A8-1

9.0 REFERENCES ..................... A9-1

PART A APPENDIX: DRAWINGS ............... AAA-1 
WHC-SD-TP-SEP-035 Rev. 1

CONTENTS (cont)

PART B: PACKAGE EVALUATION .............. B1-1

1.0 INTRODUCTION . . . . . . . . . . . . . . . B1-1

1.1 SAFETY EVALUATION METHODOLOGY ............ B1-1

1.2 EVALUATION SUMMARY AND CONCLUSION .......... Bl-1

2.0 CONTENTS EVALUATION ................ . . . . . . . .

2.1 CHARACTERIZATION ................. B2-1

2.2 CONTENTS DATA AND RESTRICTIONS FOR BOX CONTAINING

FIVE UPPER VAULT ION EXCHANGE COLUMNS ......... B2-3

2.2.1 Source Term ............. B2-3

2.2.2 Total Activity . . . . . . . . . . . B2-3

2.2.3 Waste Category . . . . . . . . . . . B2-4

2.2 .4 Dimensions.............. . . B2-4

2.2 .5 Total Volume . . . . . . . . . . . . B2-5

2.2.6 Gross Weight . . . . . . . . . B2-5

2.3 CONTENTS DATA AND RESTRICTIONS FOR METAL BOX CONTAINING
THREE LOWER VAULT COLUMNS ..... B2-6

THREE LOWER VAULT COLUMNS $\ldots \ldots \ldots$

2.3.2 Total Activity . . . . . . . . . . . . . . . B B2-6

2.3.3 Waste Category . . . . . . . . . . B2-7

2.3.4 Dimensions ............. . . . B2-7

2.3 .5 Total Volume . . . . . . . . . . B2-8

2.3.6 Gross Weight . . . . . . . . B2-8

2.4 CONTENTS DATA AND RESTRICTIONS FOR METAL BOX CONTAINING
FOUR LOWER VAULT COLUMNS ...... B2-9

2.4.1 Source Term . . . . . . . . . . . . . . . . . . . B2-9

2.4 .2 Total Activity . . . . . . . . . . . B2-9

2.4.3 Waste Category . . . . . . . . . . B2-10

2.4 .4 Dimensions . . . . . . . . . . . . B2-11

2.4 .5 Total Volume ............. B2-11

2.4 .6 Gross Weight . . . . . . . . . . . B2-12

2.5 CONCLUSIONS . . . . . . . . . . . . . B2-12

3.0 CONTAINMENT EVALUATION . . . . . . . . . . . . . B3-1

3.1 INTRODUCTION . . . . . . . . . . . . . . . . . . B3-1

3.2 CONTAINMENT SOURCE SPECIFICATION .......... B3-1

3.3 NORMAL TRANSFER CONDITIONS ............ B3-1

3.4 CONTAINMENT EVALUATION CONCLUSIONS ......... B3-2

4.0 SHIELDING EVALUATION . . . . . . . . . . . . . . . . B4-1

4.1 INTRODUCTION . . . . . . B4-1

4.2 DIRECT RADIATION SOURCE SPECIFICATION ......... B4-1

4.3 SUMMARY OF SHIELDING PROPERTIES OF MATERIAL . . . . . . . B4-1

4.4 NORMAL TRANSFER CONDITIONS ............ . B4-1

4.5 SHIELDING EVALUATION AND CONCLUSIONS ......... B4-2

APPENDIX B-1: 309 BUILDING TANK FARM .......... . BA-1 


\section{CONTENTS (cont)}

5.0 STRUCTURAL EVALUATION ................ B5-1

5.1 INTRODUCTION ................... B5-1

5.2 STRUCTURAL EVALUATION OF PACKAGE ......... B5-1

5.2.1. Structura1 Design and Features Offered by the Metal

Boxes ${ }^{2}$. . . . . . B5-1

5.2.2 Chemical and Galvanic Reactions ........ B5-2

5.2.3 Tamper-Indicating Feature ........ B5-2

5.2.4 Lifting and Tiedown Devices .......... B5-2

5.2 .5 Positive Closure ........... B5-2

5.2.6 Weights and Center of Gravity . . . . . . . B5-2

5.2.7 Tamper-Indicating Feature ........ B5-2

5.2.8 Lifting and Tiedown Devices ......... B5-2

5.3 NORMAL TRANSFER CONDITIONS ........ B5-2

5.4 STRUCTURAL EVALUATION AND CONCLUSIONS ........ B5-3

APPENDIX B-2: SHIRAGA ENGINEERING SAFETY EVALUATION . . . . . BB-1

6.0 THERMAL EVALUATION ................ B6-1

6.1 INTRODUCTION . . . . . . . . . . . . . B6-1

6.2 SUMMARY OF THERMAL PROPERTIES OF MATERIALS ....... B6-1

6.3 SUMMARY OF THERMAL PROPERTIES OF MATERIALS ....... B6-1

6.4 THERMAL EVALUATION FOR NORMAL TRANSFER CONDITIONS .... B6-2

6.5 THERMAL EVALUATION AND CONCLUSIONS ......... B6-2

7.0 PRESSURE AND GAS EVALUATION . . . . . . . . . . . B7-1

7.1 GAS GENERATION . . . . . . . . . . . . B7-1

7.2 PACKAGE PRESSURE AND FLAMMABLE GAS CONCLUSIONS ..... B7-1

APPENDIX B-3: ION EXCHANGE COLUMN $\mathrm{H}_{2}$ GENERATION ENGINEERING SAFETY

EVALUATION ....................... BC-1

8.0 PACKAGE TIEDOWN SYSTEM EVALUATION .............. B8-1

8.1 SYSTEM DESIGN . . . . . . . . . . . . . . B8-1

8.2 ATTACHMENTS AND RATINGS .............. . . . B8-1

9.0 REFERENCES ..................... B9-1 
WHC-SD-TP-SEP-035 Rev. 1

LIST OF TABLES

PART A

A-1. Smearable Contamination Limits . . . . . . . . . . . . A6-1

PART B

B-1 Contents of Ion Exchange Columns . . . . . . . . . . . B2-2

B-2 Activity Limits for Type A Packages . . . . . . . . . . . . . . . B2-4

B-3 Determination of Category 1 Waste . . . . . . . . . . . . . . B2-4

B-4 Dimensions of Upper Vault Columns . . . . . . . . . . . . . . . B2-5

B-5 Volume Calculations for Upper Vault Column Packaging . . . . . . B2-5

B-6 Gross Weight Calculations . . . . . . . . . . . . . . . . B2-6

B-7 Activity Limits for Type A Packages . . . . . . . . . . . . . . . B2-7

B-8 Category 3 Determination . . . . . . . . . . . . . . . . . . B2-7

B-9 Dimensions of Three Lower Vault Columns. . . . . . . . . . . . . B2-8

B-10 Three Lower Vault Column Volume Calculations . . . . . . . . . B2-8

B-11 Gross Weight Calculations . . . . . . . . . . . . . . . . B2-9

B-12 Type A Packaging Activity Limits . . . . . . . . . . . . . . . . B2-10

B-13 Calculations for Category 3 Determination. . . . . . . . . . . B2-11

B-14 Dimensions of Four Lower Vault Columns . . . . . . . . . . . B2-11

B-15 Volume of Lower Vault Columns................. . B2-12

B-16 Gross Weight of Metal Box with Four Columns... . . . . . . . . B2-12

B-17 Input Values Used in Spreadsheet . . . . . . . . . . . . . . . B7-1

B-18 $\mathrm{H}_{2}$ Generation Results .................... . B7-2 
WHC-SD-TP-SEP-035 Rev. I

This page intentionally left blank. 


\section{THIS PAGE INTENTIONATKY}

\section{LEFT BLANK}


WHC-SD-TP-SEP-035 Rev. 1

\section{SAFETY EVALUATION FOR PACKAGING FOR ONSITE \\ TRANSFER OF PLUTONIUN RECYCLE TEST \\ REACTOR ION EXCHANGE COLUNNS}

\section{PART A: DESCRIPTION AND OPERATIONS}

\subsection{INTRODUCTION}

\subsection{GENERAL INFORMATION}

The purpose of this Safety Evaluation for Packaging (SEP) is to authorize the use of $3 \mathrm{U}$.S. Department of Transportation (DOT) 7A Type A metal boxes (Capital Industries Part No. S 0600-0600-1080-0104) to package 12 Plutonium Recycle Test Reactor (PRTR) ion exchange columns as low-level waste (LLW). The packages will be transferred from the 309 Building in the 300 Area to low level waste burial in the 200 West Area.

One metal box contains five upper vault columns (see the Part A Appendix for drawing). The total activity in this box meets the activity limits for Type $A$ packages found in 49 CFR 173.431(a), "Activity Limits for Type A and Type B Packages." However, the weight of the packaged columns exceeds the maximum gross weight limitation of 7,000 1b specified by the manufacturer (see Part $B$, Section 5.0 for structural evaluation). This package is also considered Category $1 \mathrm{LLW}$ waste per WHC-EP-0063, Hanford Site Solid Waste Acceptance Criteria, Section 3, and Appendix K.

Two boxes contain ion exchange columns from the lower storage vault (see Part A Appendix for drawing). These packages meet the activity limits for Type A packages found in 49 CFR 173.431 (a). These packages also exceed the maximum gross weight limitation of 7,000 1b because they are considered Category 3 LLW as defined in WHC-EP-0063, Section 3, and Appendix $K$, thus requiring stabilization using grout as the stabilization media (see Part B, Section 5.0 for structural evaluation). Because of deflection of the boxes near the flange of the 1 id and excess grout, each box containing grout will be shipped without a lid. The exposed grout in these boxes will be covered with plastic to keep the grout from being exposed to adverse weather conditions.

The following analyses are used to demonstrate the safety of the metal boxes under the conditions already described:

- Containment evaluation

- Shielding evaluation

- Structural analysis

- Thermal generation

- $\mathrm{H}_{2}$ gas generation

- Tiedown system analysis.

Based on the overweight characteristics of the packaged columns and because the lids will be left off of the Category $3 \mathrm{LLW}$ boxes, the section of road on which the shipment will be transported that normally is open to public access shall be closed to exclude the public and nonessential workers from access to the 
shipment.

Road closure ensures that this shipment is not considered "in commerce" where DOT regulations govern transportation.

\subsection{SYSTEM DESCRIPTION}

The packaging used to contain the 12 ion exchange columns is $5-\mathrm{ft} \times 5-\mathrm{ft} \times$ 9-ft 7A, Type A metal boxes. These metal boxes were manufactured by Capital Industries, Inc. (Part No. S 0600-0600-1080-0104).

These metal boxes (Part No. S 0600-0600-1080-0104) were designed and qualified by analys is to meet 49 CFR 178.350, "Specification 7A, General Packaging, Type A," in accordance with Capital Industries Inc. , Part No. S 0483-0510-0823-0104 and Part No.V 0483-0510-0283-0104 vented container. (See Capital Industries, Container Certification Analysis for Part No. S-0600-0600-1080-0104). 


\subsection{PACKAGING SYSTEMS}

\subsection{CONFIGURATIONS AND DINENSIONS}

The Capital Industries Inc., 7A, Type $A$, metal box (Part No. $S$ 0600-0600-1080-0104) is designed and certified by analys is to meet the requirements for DOT 7A, Type A packages outlined in 49 CFR 178.350. This metal box is essentially designed to maintain a payload limited to a maximum of $1-A_{1}$ (special form) or $1-A_{2}$ (normal form) quantity of radioactive material per 49 CFR 173.433 and 49 CFR 173.435 under normal conditions of transport. Normal conditions of transport are identified in 10 CFR 71.71 .

Specifications for the metal box used to package the ion exchange columns are as follows.

Overall dimensions $\quad 66$ in. wide, 63-1/4 in. deep, 114-3/4 in. long

Interior dimensions $60 \mathrm{in.}$ wide, $60 \mathrm{in.}$ deep, $108 \mathrm{in.}$ long

Number of corrugations 24.

\subsection{MATERIALS OF CONSTRUCTION}

Material 10-gauge bottom, 12-gauge 1 id and sides $A 570$ hot rolled sheet steel and A36 structural members and 3/16-in.-thick plate

Lid reinforcing Angle 3 in. $\times 7 / 16$ in. $\times 3 / 16$ in., around 1 id perimeter Lid seal 2-in. wide, 1/4-in. thick, commercial 30 durometer neoprene Lid fasteners, $1 / 2$ in. $-13 \times 1-1 / 2-i n$. stainless steel. bolts, and nuts

\subsection{DESIGN AND FABRICATION METHODS}

The boxes used to package the ion exchange columns are welded metal boxes designed in accordance with Capital Industries, Inc. specification S 0600-06001080-0104.

\subsection{WEIGHTS AND CENTER OF GRAVITY}

The weight of the packaged columns is assumed to be at the geometric center of the box.

$\begin{array}{lr}\text { Total Weight } & 1,620 \mathrm{lb} \\ \text { Weight, box } & 1,245 \mathrm{lb} \\ \text { Weight, 1id and stiffeners } & 375 \mathrm{lb} \\ \text { Certified weight } & 7,000 \mathrm{lb} \\ \text { Maximum gross weight } & 24,900 \mathrm{lb} .\end{array}$


WHC-SD-TP-SEP-035 Rev. 1

\subsection{CONTAINMENT BOUNDARY}

The containment boundary for the Category $1 \mathrm{LLW}$ box is considered to be the top, bottom, and sides of the box, the neoprene gasket, and the lid. The containment boundary for the two Category 3 LLW boxes is considered to be the bottom and sides of the box and the top layer of grout because each box will be shipped without a lid.

\subsection{VOLUME (CAVITY SIZE)}

$225.0 \mathrm{ft}^{3}$ (60 in. $\times 60$ in. $\times 108$ in. $)$.

\subsection{HEAT DISSIPATION}

The payload produces a low enough level of heat (less than 1 watt per box) that passive cooling meets the heat dissipation requirements.

\subsection{SHIELDING}

The metal box affords only a minimum amount of shielding provided by the metal walls of the box (see Part B, Section 4.0).

\subsection{LIFTING DEVICES}

Lifting equipment used shall conform to the requirements of the U.S. Department of Energy, Richland Operations Office (RL), Hanford Site Hoisting and Rigging Manual.

\subsection{TIEDOWN DEVICES}

The nylon straps and fasteners used to tie the boxes to the trailer shall be in compliance with 49 CFR 393.102, "Tiedown Assemblies."

\subsection{OPERATIONAL FEATURES}

No sophisticated operations are required to close the box containing Category $1 \mathrm{LLW}$. Box closure operations for the box containing Category $1 \mathrm{LLW}$ requires inserting the payload in the box then securing the gasket and $1 \mathrm{id}$.

Box closure operations for the two boxes containing the Category $3 \mathrm{LLW}$ includes inserting the payload in the box then covering the top of the box with plastic. 


\subsection{PACKAgE CONTENTS}

\subsection{GENERAL DESCRIPTION}

The 12 ion exchange columns are packaged in three 7A, Type $A$ metal boxes. In the configuration in which they are to be packaged (see Appendix $A$, drawings $10-1,10-2$, and $10-3$ ), each box is considered to contain a Type $A$ quant ity of radioactive material as defined in 49 CFR 173.433 and 49 CFR 173.435. The payload is also considered to be fissile exempt (less than 15 grams of fissile material per box, per Part B, Section 2.0).

The packaging is configured in accordance with the description provided in Part B, Section 2.0, and Part A, Appendix, Attachment 1.

\subsection{CONTENTS RESTRICTIONS}

The following is a characterization summary of the ion exchange columns based on non-destructive analysis, data established before the non-destructive analysis, and Part B, Section 2.0:

One box will contain five ion exchange columns from the upper vault. The box will contain miscellaneous waste. Pyro foam will be used to fill void space inside the box. The box will contain $0.0937 \mathrm{Ci}{ }^{60} \mathrm{Co}$, $0.0101 \mathrm{Cj}{ }^{137} \mathrm{Cs}$, and $0.001648 \mathrm{Ci}{ }^{90} \mathrm{Sr} /{ }^{90} \mathrm{Y}$. The box will weigh no more than $8,3201 b$.

A second box will contain three ion exchange columns from the lower vault. The box will contain $0.32730 \mathrm{Ci}{ }^{60} \mathrm{Co}, 0.06837 \mathrm{Ci}{ }^{137} \mathrm{Cs}$, and $0.01094 \mathrm{Ci}{ }^{90} \mathrm{Sr} /{ }^{90} \mathrm{Y}$. Grout will be used to fill the void space inside the box. The box will weigh no more than $24,9001 \mathrm{~b}$.

A third box will contain four ion exchange columns from the lower vaylt. The box will contain $0.13322 \mathrm{Ci}{ }^{60} \mathrm{Co}, 0.45689 \mathrm{Ci}{ }^{137} \mathrm{Cs}, 2.0 \mathrm{PC}$ $\mathrm{Pu}^{239}$, and $0.07310 \mathrm{Ci}{ }^{90} \mathrm{Sr} /{ }^{90} \mathrm{Y}$. Grout. will be used to fill the void space inside the box. The box will weigh no more than 21,700 1b.

The payloads are considered LLW. The boxes do not contain nonradioactive hazardous material. See Part B, Section 2.0 for a detailed contents analys is of the payloads. See Part B, Section 2.0 of this SEP for a detailed analysis of the payload contents.

'Pyro foam is a registered trademark of Pyro Foam, Inc. 
WHC-SD-TP-SEP-035 Rev. 1

\subsection{TRAMSPORT SYSTEM}

\subsection{TRANSPORT VEHICLE}

The transport vehicle is a 50-ft long by 10-ft wide trailer. The trailer conforms to DOT annual inspection requirements found in 49 CFR 396.3 , "Inspection, Repair, and Maintenance," and 49 CFR 396.17, "Periodic Inspection."

\subsection{TIEDOWN SYSTEM}

The nylon straps and fasteners used to tie down the boxes to the trailer are in compliance with 49 CFR 393.102, "Tiedown Assemblies." The straps are rated at 12,000 1b. Bracing will include I beams chained to the trailer, with one I beam on each of the four linear sides of the boxes.

\subsection{SPECIAL TRANSFER REQUIREMENTS} requirements.

The following arrangements have been made to meet special transfer

- The boxes exceed the manufacturer's maximum gross weight limit of $7,000 \mathrm{lb}$. In addition, the boxes containing Category 3 LLW will not have lids attached to the boxes. Therefore, the section of the road on which the shipment will be transported that is normally open to the public shall be closed to the public and non-essential workers.

- The transport vehicle will be visually inspected before loading to ensure that it is acceptable for use.

- The boxes will be radiologically surveyed before loading.

- All rigging hardware, attachments, and associated equipment will be visually inspected to ensure that they are working properly.

- The tiedown straps, tension devices, and associated attachments will be visually inspected to ensure that they are working properly.

- The Category 1 LLW box will be visually inspected to ensure that containment surfaces and the lid sealing interface have no visible breaches. The Category 3 LLW will be visually inspected to ensure that the exposed grout is covered with plastic, and that there are no visible breaches in the box or plastic covers.

- Transport vehicle speed will be limited to posted speed limits.

- The transport route will be the shortest available route using normal Hanford Site paved roadway.

- The boxes will not be transferred during periods of inclement weather (i.e., winds in excess of $35 \mathrm{mph}$, heavy driving rain, blowing dust that results in poor visibility). 
- The transport vehicle will be equipped with a fire extinguisher capable of extinguishing a Class $A, B$, or $C$ fire. The driver of the vehicle will be trained and qualified to use the fire extinguisher.

- In the event of an accident involving the transport vehicle, onsite emergency response guidelines will be followed.

- The requirements of WHC-CM-2-14, Hazardous Material Packaging and Shipping will be followed while transferring the boxes.

- Dose rate readings have shown that the maximum dose rate is $400 \mathrm{mRem} / \mathrm{hr}$ at the surface of the boxes. (See Part B, Section 4.5.) To meet as low as reasonably achievable (ALARA) principles, the boxes will be configured on the trailer to limit the dose rate on the surface of each package facing outside of the trailer. The surface dose rate readings on the cab of the tractor shall not exceed $2 \mathrm{mRem} / \mathrm{hr}$.

- The transfer will be made during off-peak traffic hours over an uncongested route. The section of road used for the transfer will be closed to ensure that nonessential personnel and the public do not have access to the boxes.

- The metal boxes tied down to the trailer will be handled as a wide load and as an overweight load. Therefore, the load will be specially permitted for both wide load and overweight conditions. 
WHC-SD-TP-SEP-035 Rev. 1

\subsection{ACCEPTANCE OF PACKAgING FOR USE}

The acceptance of the metal boxes for packaging the ion exchange columns is based on the evaluations presented in Part B of this SEP. The metal boxes are accepted as 7A, Type A, metal boxes per 49 CFR 178.350, in accordance with Capital Industries, Inc. Specification No. S 0600-0600-1080-0104 and as indicated in Sections 1.2 .1 and 2.1 of this SEP. The metal boxes are also accepted per QR 7.0 "Control of Purchased Items and Services" contained in WHC-CM-4-2, Quality Assurance. 
WHC-SD-TP-SEP-035 Rev. 1

\subsection{OPERATING REQUIREMENTS}

\subsection{CONTENTS RESTRICTIONS}

The contents of the three metal boxes shall not exceed the restrictions found in Section 3.2. Smearable contamination 1 imits shall not.exceed those in Table A-1.

Table A-1. Smearable Contamination Limits.

\begin{tabular}{|c|c|c|}
\hline . & $\begin{array}{c}\text { Removable } \\
\{\mathrm{dpm} / 100 \mathrm{~cm}\}^{2}\end{array}$ & $\begin{array}{l}\text { Total } \\
\text { (Fixed }+ \text { Remoyable) } \\
\left(\text { dpm/100 } \mathrm{cm}^{2}\right)^{3}\end{array}$ \\
\hline U-natural, ${ }^{235} \mathrm{U},{ }^{238} \mathrm{U}$, and associated decay products. & 220 alphe ${ }^{4}$ & 5.000 alpha \\
\hline Transuranics, ${ }^{226} \mathrm{As},{ }^{228} \mathrm{Fa},{ }^{230} \mathrm{Th},{ }^{228} \mathrm{Th},{ }^{231} \mathrm{~Pa}, 227_{\mathrm{Ac},}{ }^{125_{\mathrm{l}}}{ }^{129}$ & 20 & 500 \\
\hline 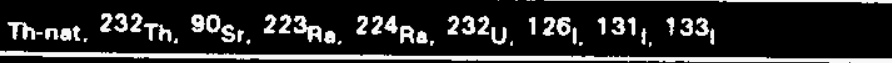 & 200 & 1,000 \\
\hline $\begin{array}{l}\text { Bota-gamma emitters (nuclides with decay modes other than alpha emission } \\
\text { or eponteneous fission) except }{ }^{90} \mathrm{Sr} \text { and athers noted above. Includes } \\
\text { mixed fission products containing }{ }^{90} \mathrm{Sr} \text {. }\end{array}$ & 1,000 beta/gamma & 5.000 beta/gamma \\
\hline \multirow{2}{*}{\multicolumn{3}{|c|}{ 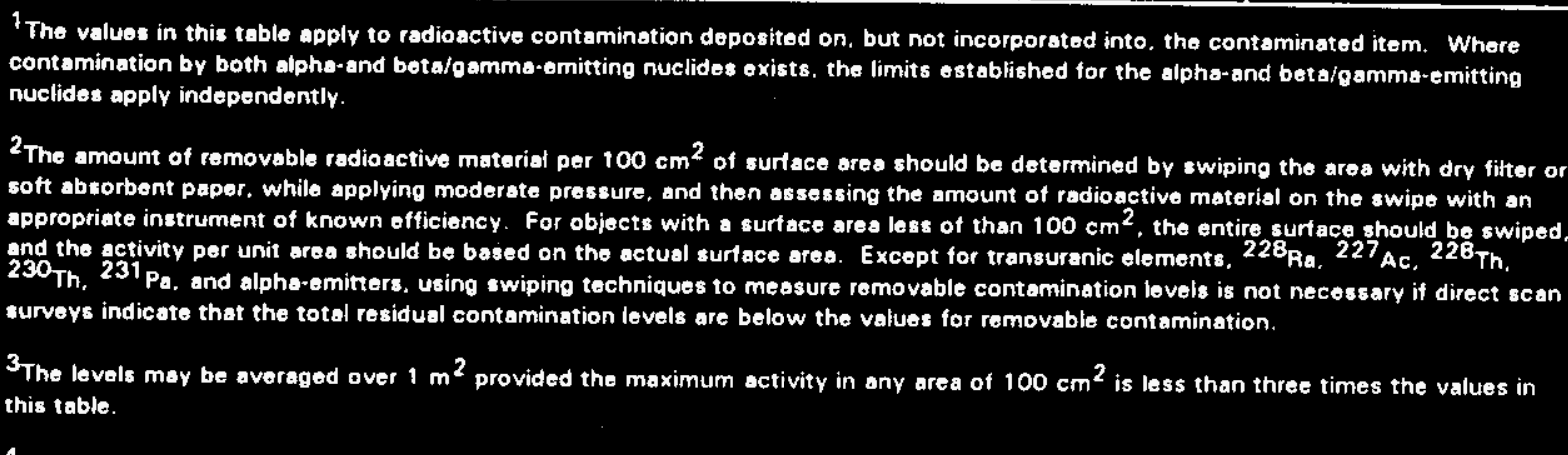 }} \\
\hline & & \\
\hline \multicolumn{3}{|c|}{$\begin{array}{l}4 \text { More restrictive level required by } 49 \text { CFR 173.443. All other limits are in accordance with the Hanford Site Radialonical Control } \\
\text { Manula (RL 1994). }\end{array}$} \\
\hline
\end{tabular}

\subsection{PACKAGE CLOSURE INSTRUCTION}

The procedure for closing the package is as follows:

1. Load the packages in accordance with Appendix A, Drawings 10-1, 10-2, and 10-3.

2. The boxes shall be properly shored during the Pyro foam and grout filling process (see Part B, Section 5.4).

3. Ensure full reaction of the Pyro foam, and a minimum of 7 days curing of the grout, both before lifting and transporting the boxes (see Part B, Section 5.4).

4. Follow the manufacturer's closure instructions (as applicable) when sealing the Category I LLW box. Ensure that the exposed grout in the Category 3 LLW boxes is covered with plastic.

5. A tamper-indicating device is not needed because the payload is either 
WHC-SD-TP-SEP-035 Rev. 1

enveloped in Pyro foam (Category I LLW) or enveloped in grout (Category III LLW).

\subsection{TRANSFER}

The boxes will be transferred in accordance with Part A, Section 4.3. 


\subsection{QUALITY ASSURANCE}

\subsection{GENERAL REQUIREMENTS}

The responsibilities of quality assurance personnel are as follows:

- Verify that the metal boxes used for packaging the columns meet the quality of design and construction requirements specified in 49 CFR $173.474(\mathrm{a})$.

- Verify that the metal boxes used for packaging the columns are in unimpaired physical condition, except for superficial marks in accordance with 49 CFR $173.475(\mathrm{~b})$.

- Verify that the Category 1 LLW box packaging closure device, including any required gasket, is properly installed, secured, and free of defects in accordance with 49 CFR $173.475(\mathrm{e})$. Verify that the Category $3 \mathrm{LLW}$ boxes have exposed grout covered with plastic in accordance with the requirements of this SEP.

- Verify that all special packaging instructions (as applicable) for filling, closing, and preparing the packaging for shipment have been followed in accordance with 49 CFR 173.475(e), and in accordance with the requirements of this SEP.

- Verify that the packaging's closure, or other openings through which radioactive material might escape are properly closed before shipment in accordance with 49 CFR $173.475(\mathrm{f})$, and in accordance with the requirements of this SEP.

- Ensure that documentation is retained in accordance with WHC-CM-2-14, Hazardous Material Packaging and Shipping, Part VII.

- Verify that the metal boxes also meet the requirements of $Q R 7.0$ "Control of Purchased Items and Services," WHC-CM-4-2, Quality Assurance.

\subsection{SEP CONTROL SYSTEM}

This SEP will be used to support the one-time shipment of the PRTR ion exchange columns from the 309 Building ion exchange column vault to low-level waste burial in the 200 West Area. This SEP will expire immediately following the shipment, or one year from the document release date, whichever is first. Use only the current and approved version of this SEP.

This SEP will be reviewed using an Engineering Data Transmittal. All comments and changes as a result of the review will be incorporated into the SEP. 
WHC-SD-TP-SEP-035 Rev. 1

\subsection{MAINTENANCE}

This SEP authorizes the one-time transfer of three 7A, Type A metal boxes containing PRTR Ion Exchange Columns from the 309 Building Ion Exchange Column Vault to low-level waste burial in the 200 West Area. There are no specific maintenance requirements. 
WHC-SD-TP-SEP-035 Rev. 1

\subsection{REFERENCES}

10 CFR 71, "Energy," Code of Federal Regulations, as amended.

49 CFR 173, "Transportation," Code of Federal Regulations, Subpart I, and 178.350 .

49 CFR 393.102, "Tiedown Assemblies," Code of Federal Regulations, as amended.

Capital Industries, Inc., Container Certification Analysis for Part Number S 0600060010800104 , Capital Industries, Inc., Seattle, Washington.

WHC-CM-1-6, Westinghouse Radiological Control Manual, Chapter 2 (Table 2-2) and Chapter 4, Article 423.

WHC-CM-4-2, Quality Assurance, Westinghouse Hanford Company, Richland, Washington.

WHC-CM-2-14, Hazardous Material Packaging and Shipping, Westinghouse Hanford Company, Richland, Washington. 


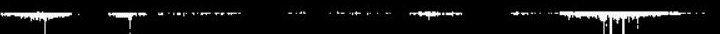


WHC-SD-TP-SEP-035 Rev. 1

\section{PART A APPENDIX}

\section{DRAHINGS}

Attachment 1 - BHI Memo Job No. 22192

AA-2 Drawing of box containing 5 upper vault columns AA-3 Drawing of box containing 3 lower vault columns

AA-4 Drawing of box containing 4 lower vault columns 


\section{Bechtel Hanford, Inc.}

450 Hills Street, Richland, WA 99352

Mailing address: P.O. Box 9.99, Aichland, WA 99352

Telephone: (509) 375-4640 Fax: (509) 375-4644

\author{
Job No. 22192 \\ Writen Repponse Required? No \\ Cloves CCN: N/A \\ OU: $\mathbf{N A}$ \\ TSD: NA \\ ERA: N/A \\ Subject Code: 1300
}

\section{$2018 \mathrm{sin}$}

Westinghouse Hanford Company

M. E. Burnside, Safety Evaluation Plan Lead

Hazardous Waste Operations

P. O. Box 1970, G2-02

Richland, Washington 99352

Dear Mr. Burnside:

\section{Subject: 309 BUILDING PLUTONIUM RECYCLE TEST REACTOR ION EXCHANGER VAULT CLEANOUT PROJECT WASTE SHIPMENT}

The subject vault cleanout project column containerization data is submitted formally for a reference in finalizing the transportation safety evaluation for packaging (SEP) for the three burial boxes containing the twelve ion exchangers (attachment 1 and 2). The Environmental Restoration Contractor (ERC) project schedule for the 309 vault cleanout requires the SEP by no later than June 19 in order to meet final packaging (i.e., Storage/Disposal Approval Record preparation, category III box grouting, etc.) and shipment milestones commitments.

If you have any questions or require additional information, please call Mr. Paul Griffin on 373-3916 or me on 373-1382.

Sincerely,

\section{ma mualu}

M. A. Mihalic

Task Lead, D\&D Projects

PWG:cmj

Attachments: 1. 309 Building Ion Exchanger Removal and Vault Cleanout Containerization Data 2. 309 Building Vault Column Packaging Configuration

cc: E. J. Bitten (WHC) L4-73, w/o

J. E. Ham (WHC) L4-73, w/o

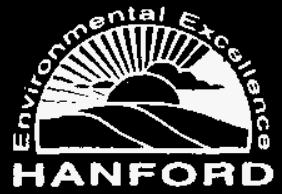


WHC-SD-TP-SEP-035 Rev. 1

015453

ATTACHMENT 1

$A A-3$ 
WHC-SD-TP-SEP-035 Rev. 1

015453

309 Building Ion Exchanger Removal and Vault Cleanout

\begin{tabular}{|c|c|c|c|c|}
\hline \multicolumn{5}{|c|}{ PRTR IX Vault Column Disposal } \\
\hline $\begin{array}{c}\text { IX I.D./ } \\
\text { (Dia.) }\end{array}$ & $\begin{array}{l}\text { Date/ } \\
\text { Time/ } \\
\text { Order } \\
\text { Removed }\end{array}$ & $\begin{array}{c}\text { Dose } \\
\text { Rate } \\
(\mathbf{m R e m} / \\
\text { Hr) }\end{array}$ & Comments /Observations & $\begin{array}{c}\text { Disposal } \\
\text { Box \# }\end{array}$ \\
\hline $\begin{array}{l}\text { DX-3F } \\
\left(18^{\prime \prime}\right)\end{array}$ & $\begin{array}{l}5-2-95 \\
3: 15 \\
1\end{array}$ & 1,500 & $\begin{array}{l}\text { Upper Vault: NDA (22 count sections): } \\
\text { Co-60 \& Cs-137: } \\
\mathrm{BF}_{3} \text { background }\end{array}$ & $\# 309-95-002$ \\
\hline $\begin{array}{l}\text { IX-2 } \\
\left(18^{\prime \prime}\right)\end{array}$ & $\begin{array}{l}5-3-95 \\
2: 36 \\
5\end{array}$ & 80 & $\begin{array}{l}\text { Upper Vault: NDA (11 count sections): } \\
\text { Co-60 \& Cs-137: } \\
\mathrm{BF}_{3} \text { background }\end{array}$ & $\# 309-95-002$ \\
\hline $\begin{array}{l}\text { IX-1 } \\
\left(30^{\prime \prime}\right)\end{array}$ & $\begin{array}{l}5-3-95 \\
10: 26 \\
2 \\
\end{array}$ & 100 & $\begin{array}{l}\text { Upper Vault: NDA ( } 11 \text { count sections): } \\
\text { Co-60 \& Cs-137: } \\
\mathrm{BF}_{3} \text { background }\end{array}$ & \#309-95-002 \\
\hline $\begin{array}{l}I X-3 \\
\left(18^{\prime \prime}\right)\end{array}$ & $\begin{array}{l}5-3-95 \\
1: 38 \\
4 \\
\end{array}$ & 180 & $\begin{array}{l}\text { Upper Vault: NDA (11 count sections): } \\
\text { Co-60 \& Cs-137: } \\
\mathrm{BF}_{3} \text { background }\end{array}$ & $\# 309-95-002$ \\
\hline $\begin{array}{l}\text { BIX-5 } \\
\left(34^{\prime \prime}\right)\end{array}$ & $\begin{array}{l}5-3-95 \\
12: 10 \\
3 \\
\end{array}$ & 35 & $\begin{array}{l}\text { Upper Vault: NDA (11 count sections): } \\
\text { Co- } 60 \text { \& Cs-137: } \\
\text { BF }_{3} \text { background }\end{array}$ & $\# 309-95-002$ \\
\hline $\begin{array}{l}\text { Lower S1 } \\
\left(18^{\prime \prime}\right)\end{array}$ & $\begin{array}{l}5-11-95 \\
4: 15 \\
6\end{array}$ & 2,500 & $\begin{array}{l}\text { Lower Vault (South Port): NDA ( } 11 \text { plus } 5 \\
\text { count sections): Co- } 60 \text { \& Cs-137: BF } \\
\text { background: (approx } 1 \text { cup water: } \\
90,000 \text { dpm) }\end{array}$ & $\# 309-95-003$ \\
\hline $\begin{array}{l}\text { Lower S2 } \\
\left(18^{\prime \prime}\right)\end{array}$ & $\begin{array}{l}5-12-95 \\
9: 00 \\
7 \\
\end{array}$ & 300 & $\begin{array}{l}\text { Lower Vault (South Port): NDA (11 count } \\
\text { sections): Co-60 \& } \\
\text { Cs-137: } \mathrm{BF}_{3} \text { background }\end{array}$ & \#309-95-003 \\
\hline $\begin{array}{l}\text { Lower S3 } \\
\left(30^{\prime \prime}\right)\end{array}$ & $\begin{array}{l}5-12-95 \\
1: 30 \\
8\end{array}$ & 30 & $\begin{array}{l}\text { Lower Vault (South Port): NDA ( } 11 \text { count } \\
\text { sections): } \mathrm{Co}-60 \text { \& } \\
\text { Cs-137: } \mathrm{BF}_{3} \text { background }\end{array}$ & $\# 309-95-003$ \\
\hline $\begin{array}{l}\text { Lower \$4 } \\
\left(30^{\prime \prime}\right)\end{array}$ & $\begin{array}{l}5-15-95 \\
10: 30 \\
9\end{array}$ & 200 & $\begin{array}{l}\text { Lower Vault (South Port): NDA (11 count } \\
\text { sections): Co-60 \& Cs-137: } \mathrm{BF}_{3} \\
\text { background: (swiped } 5 / 12 / 958-9 \mathrm{~K} \mathrm{dpm} \\
\mathrm{H}_{3} \text { ): (uprighted for drain over Sat/Sun; } \\
\text { approx third of a cup of water in discharge } \\
\text { pipe elbow 5-15-95) }\end{array}$ & $\# 309-95-004$ \\
\hline $\begin{array}{l}\text { Lower \$5 } \\
\left(18^{\prime \prime}\right)\end{array}$ & $\begin{array}{l}5-15-95 \\
2: 15 \\
10\end{array}$ & 1,300 & $\begin{array}{l}\text { Lower Vault (North Port): NDA (11 count } \\
\text { sections): Co-60 \& } \\
\text { Cs-137: BF } 3 \text { background }\end{array}$ & \#309-95-004 \\
\hline
\end{tabular}


WHC-SD-TP-SEP-035 Rev. 1

015453

\begin{tabular}{|l|l|l|l|l|}
\hline $\begin{array}{c}\text { IX I.D./ } \\
\text { (Dia.) }\end{array}$ & $\begin{array}{c}\text { Date/ } \\
\text { Time/ } \\
\text { Order } \\
\text { Removed }\end{array}$ & $\begin{array}{c}\text { Dose } \\
\text { Rate } \\
(\mathrm{mRem} / \\
\mathrm{Hr})\end{array}$ & \multicolumn{1}{|c|}{ Comments /Observations } & $\begin{array}{c}\text { Disposal } \\
\text { Box \# }\end{array}$ \\
\hline $\begin{array}{l}\text { Lower S6 } \\
\left(30^{\prime \prime}\right)\end{array}$ & $\begin{array}{l}5-16-95 \\
11: 40\end{array}$ & 150 & $\begin{array}{l}\text { Lower Vault (North Port): NDA (11 count } \\
\text { sections): Co-60 \& } \\
\text { Cs-137: BF } 3 \text { background }\end{array}$ & \#309-95-004 \\
\hline $\begin{array}{l}\text { Lower S7 } \\
\left(30^{\prime \prime}\right)\end{array}$ & $\begin{array}{l}5-16-95 \\
2: 00\end{array}$ & 120 & $\begin{array}{l}\text { Lower Vault (North Port): NDA (11 count } \\
\text { sections): Co-60 \& } \\
\text { Cs-137: *BF } 3 \text { above-background }\end{array}$ & \#309-95-004 \\
\hline * Column S7: BF 3 above-background just discernable of some transuranic radionuclides (less than
\end{tabular}

* Column $\mathrm{S} 7: \mathrm{BF}_{3}$ above-background just discernable of some transuranic radionuclides (less than minimum quantitative level). 
WHC-SD-TP-SEP-035 Rev. ]

015453

\section{ATTACHMENT 2}

\section{VAULT COLUMN PACKAGING CONFIGURATION}


WHC-SD-TP-SEP-035 Rev. 1

015453

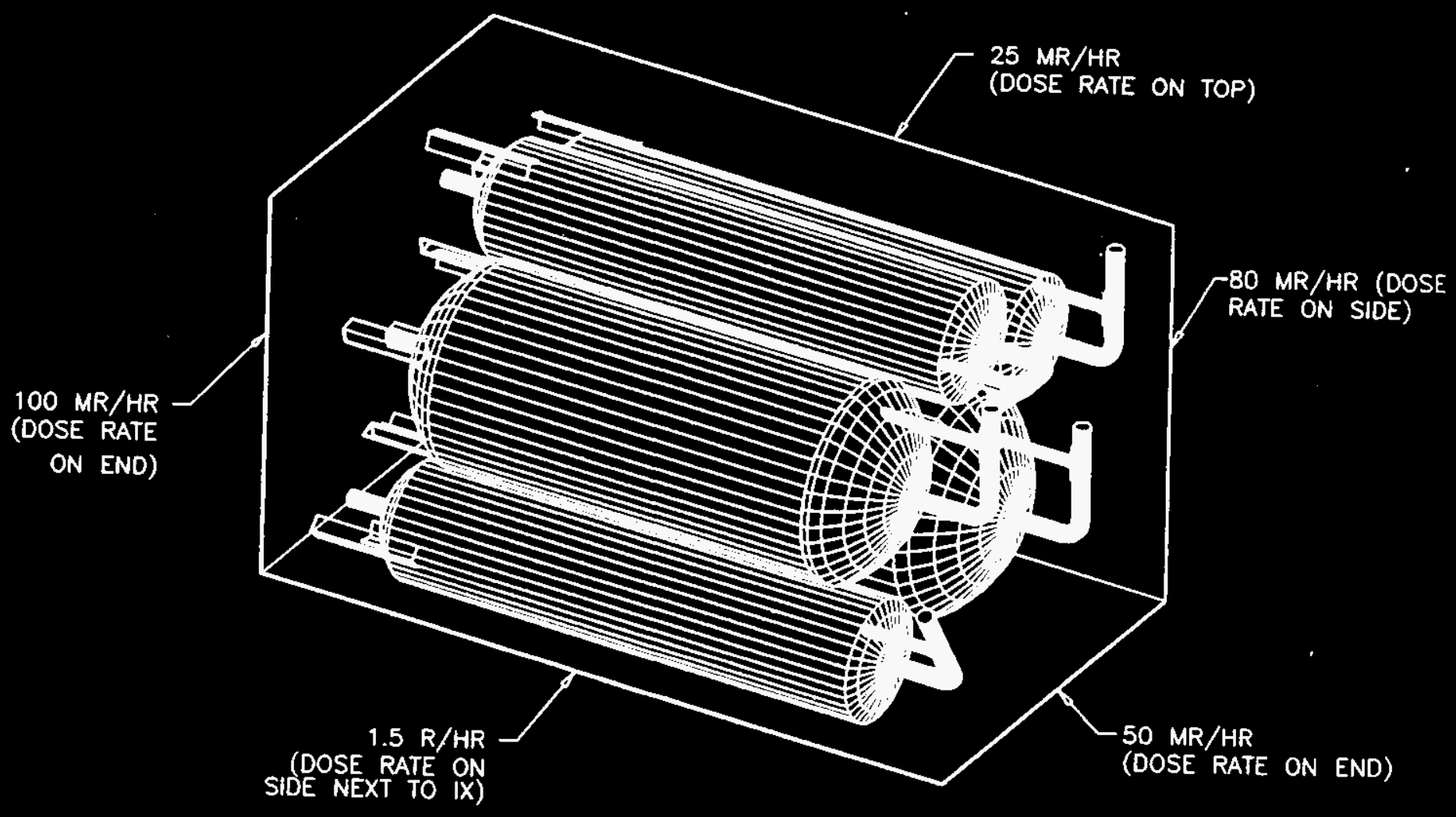

BOX \#309-95-002

LOWER VAULT COLUMNS

(LLW CAT 1)

CONTAINER:

DOT 7A, TYPE A

$5^{\prime} \times 5^{\prime} \times 9^{\prime}$

CAPITAL INDUSTRIES INC., PO W349279

8,230 ibs APPROX. TOTAL $W T$. (BOX, IX, PYRO FOAM) 


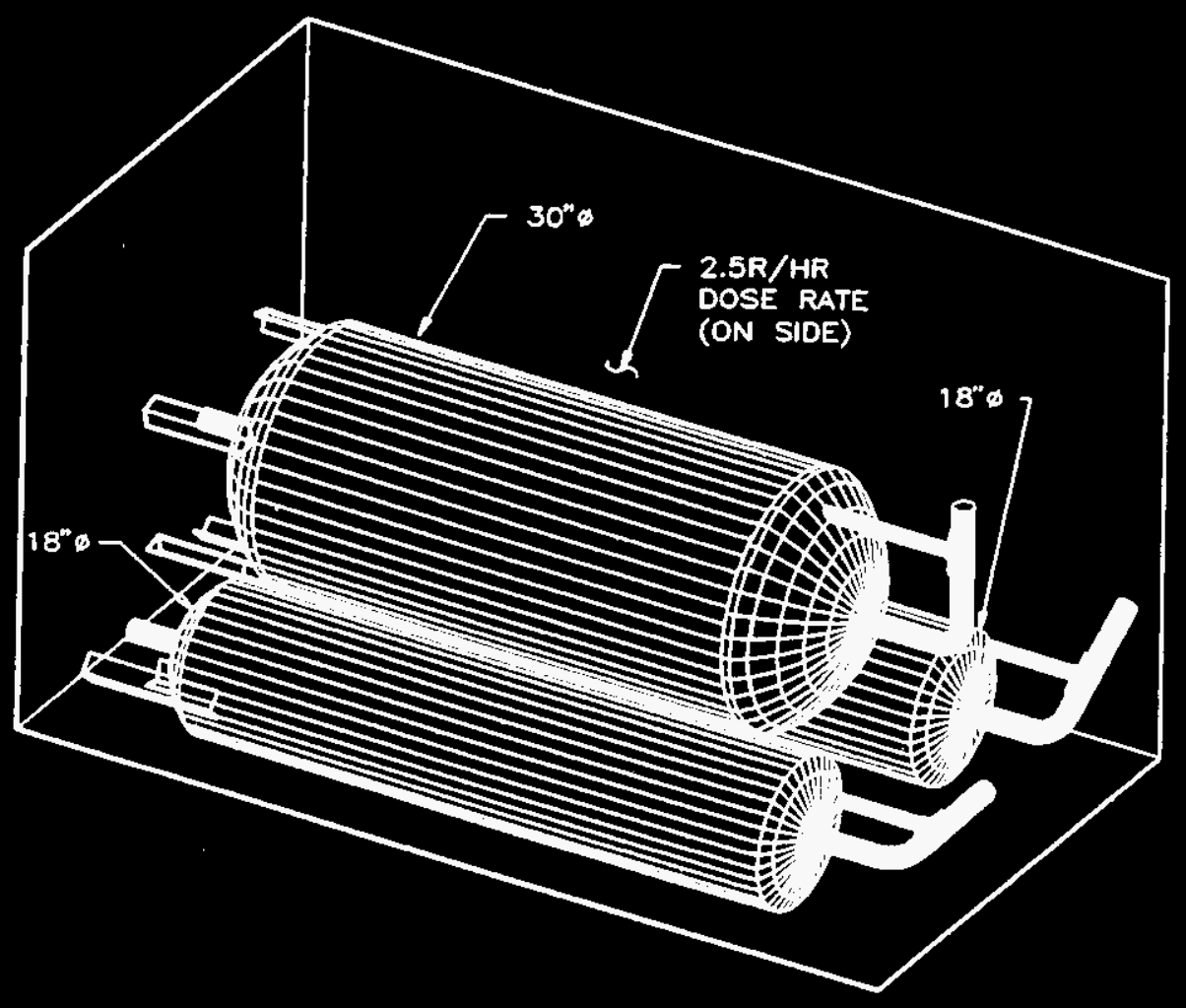

BOX \#309-95-003
LOWER VAULT COLUMNS

(LLW CAT III)

\section{CONTAINER:}

DOT 7A, TYPE A

$5^{\prime} \times 5^{\prime} \times 9^{\prime}$

CAPITAL INDUSTRIES INC., PO W349279

24,900 IbS APPROX. TOTAL WT. (BOX, IX, GROUT) 


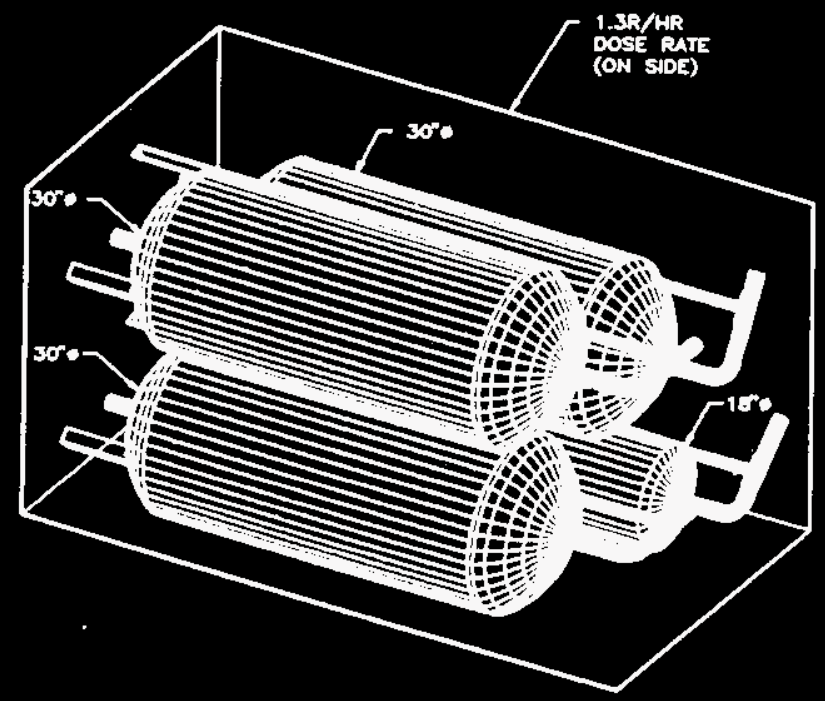

BOX \#309-95-004

LOWER VAULT COLUMNS

(LLW CAT III)

CONTAINER:

DOT 7A, TYPE A

$5^{\prime} \times 5^{\prime} \times 9^{\prime}$

CAPITAL INDUSTRIES INC., PO W349279

21,700 Ibs APPROX. TOTAL WT. (BOX, IX, GROUT) 


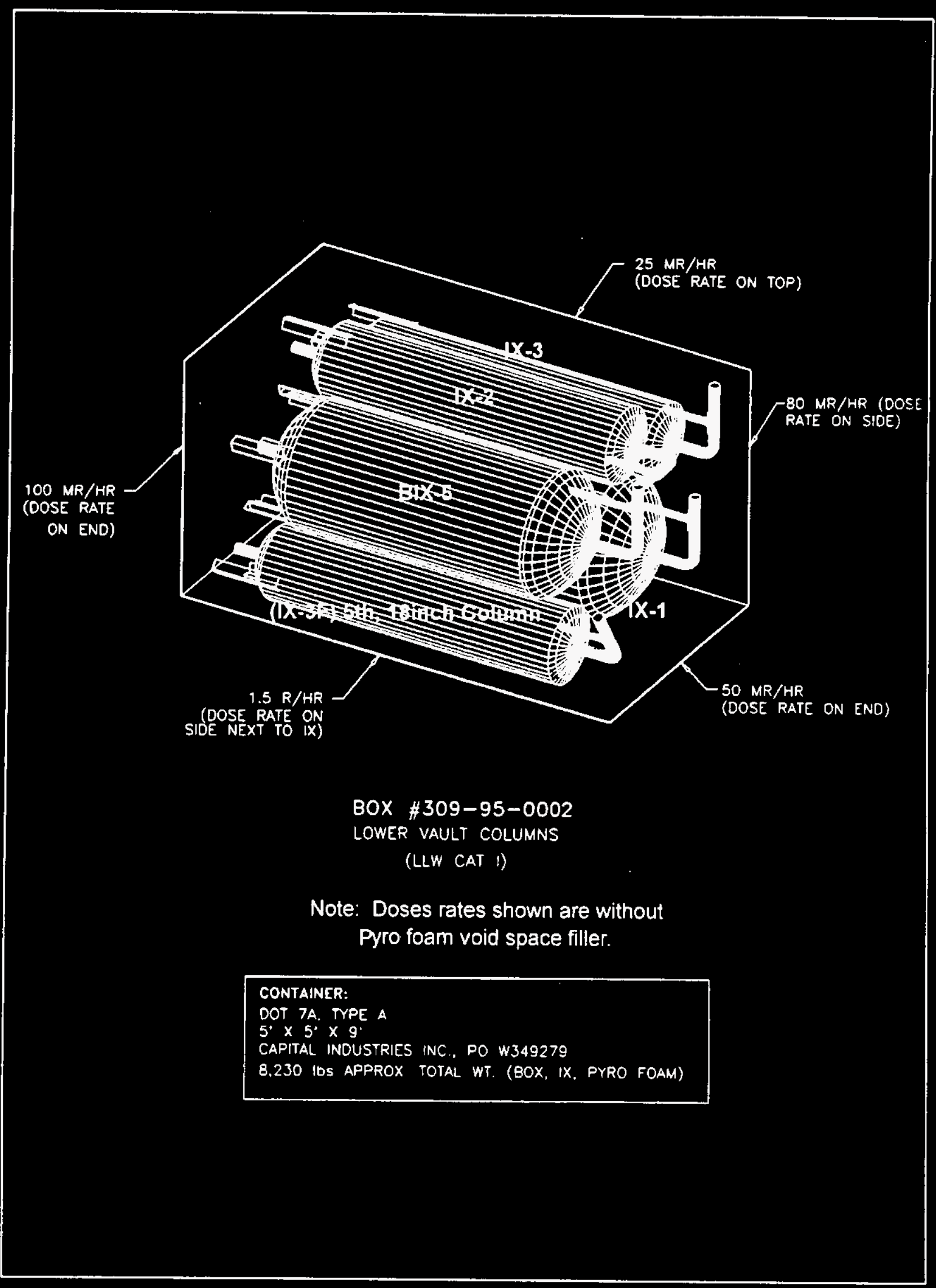




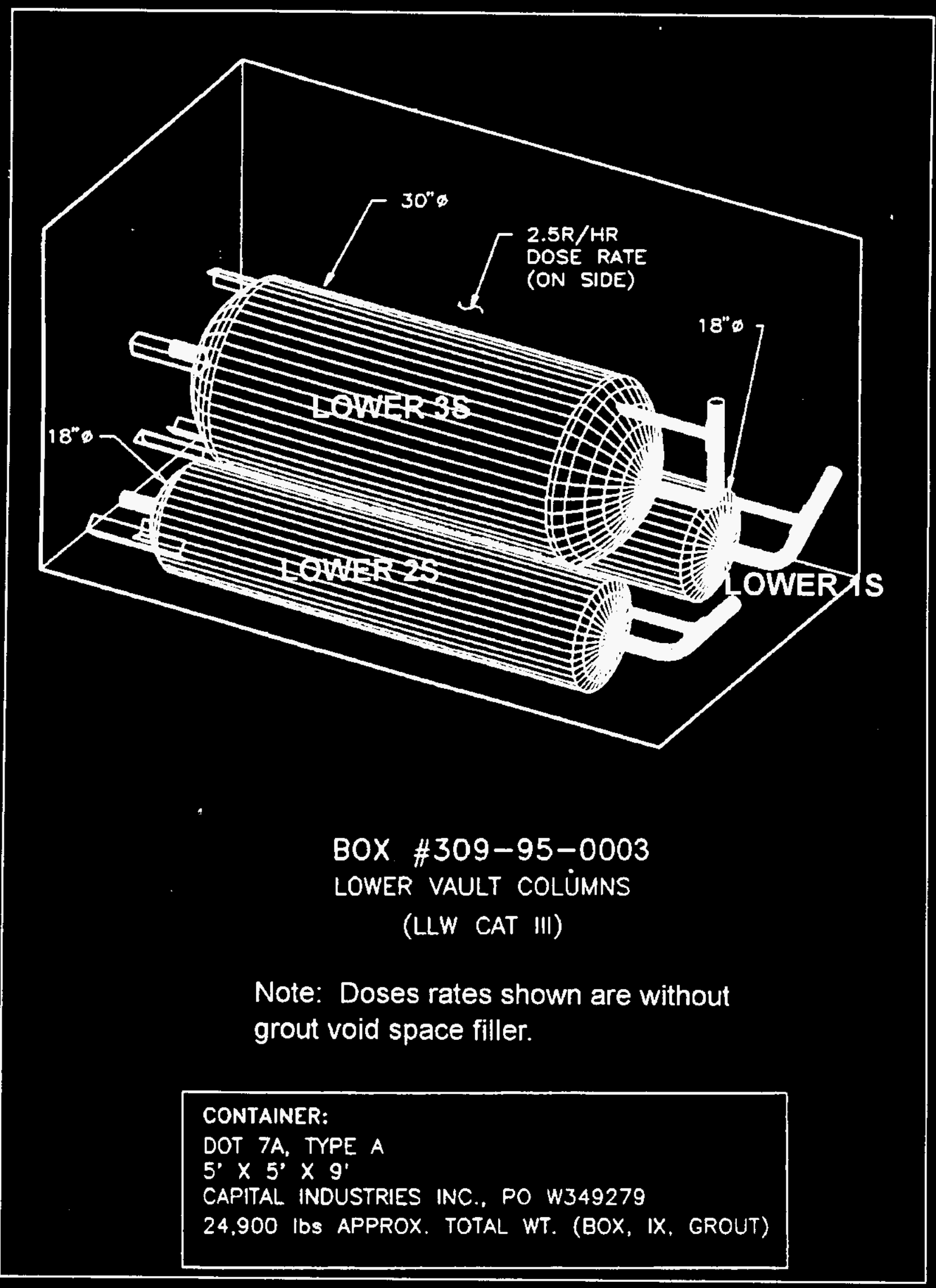


WHC-SD-TP-SEP-035 Rev. 1

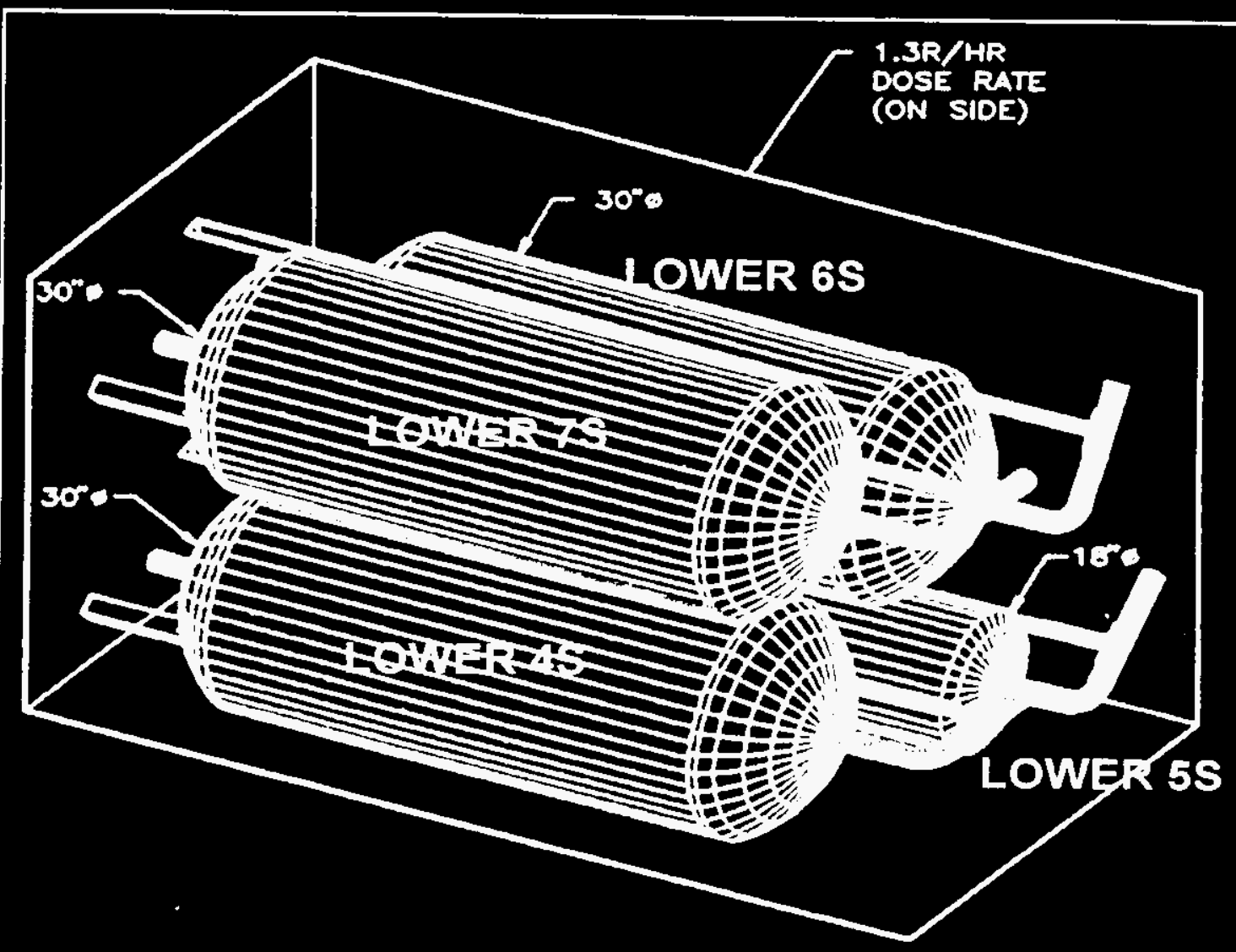

BOX \#309-95-0004

LOWER VAULT COLUMNS

(LLW CAT III)

Note: Dose rates shown are without grout void space filler.

CONTAINER:

DOT 7A, TYPE A

$5^{\circ} \times 5^{\prime} \times 9^{\prime}$

CAPITAL INDUSTRIES INC., PO W349279

21,700 lbs APPROX. TOTAL WT. (BOX, IX, GROUT) 


$$
\text { WHC-SD-TP-SEP-035 Rev. } 1
$$

\section{PART B: PACKAGE EVALUATION}

\subsection{INTRODUCTION}

\subsection{SAFETY EVALUATION METHODOLOGY}

This safety evaluation of the packaged ion exchange columns demonstrates that the payloads specified can be packaged and transported in a manner that is safe for workers, the public, and the environment, in accordance with established policies and procedures.

The primary conditions addressed in this SEP are as follows:

The over-weight condition of the boxes as a result of filling void spaces with Pyro foam and grout.

The lids will not be secured to the Category 3 LLW boxes during transport.

- The dose rates exceed DOT 1 imits and Hanford Site Radiological Control limits.

The excessive weight condition and Category $3 \mathrm{LLW}$ box lid removal are both evaluated in Part B, Sections 3.0 and 5.0 of this SEP. The dose rate conditions are addressed in Part B, Section 4.0 of this SEP.

\subsection{EVALUATION SUMMARY AND CONCLUSION}

Based on evaluations of the data provided in Part B, Section 2.0, the packaging and shipping methodology prescribed in Part $A$ is acceptable for transferring the ion exchange columns.

The containment evaluation in Part $B$, Section 3.0 demonstrates that the package will maintain its contents as stated.

The shielding evaluation (Part B, Section 4.0) demonstrates that, with administrative controls used while loading the boxes onto the trailer, the boxes can be transferred in a manner consistent with ALARA practices.

The structural evaluation documented in Part B, Section 5.0 demonstrates that, with certain controls administered, the packaged ion exchange columns can be loaded, lifted, and transported safely.

Evaluations of hydrogen generation show that the packaged columns will not generate enough hydrogen to be a concern (see Part B, Section 7.0).

Heat generation also is not a concern raised by packaging the columns in the metal boxes, as indicated in Part B, Section 2.0. The thermal evaluation is provided in Part B, Section 6.0 . 
WHC-SD-TP-SEP-035 Rev. 1

\subsection{CONTENTS EVALUATION}

\subsection{CHARACTERIZATION}

The contents characterization of the 12 ion exchange columns is based on non-destructive analys is of the ion exchange columns as each column was removed from the vault. Activity associated with the upper vault columns was established on May 18, 1995, and activity associated with the lower vault column data was established on May 24, 1995. Dose rates are determined based on survey readings obtained as the columns were removed from the vault. Non-radioactive hazardous materials are not present in the columns.

The Plutonium Recycle Test Reactor (PRTR) Ion Exchanger Vault (309 Building) contained 12 ion exchange columns left over from PRTR reactor operations. Five columns were located in the upper operation vault and seven were in the lower storage vault. The five columns from the upper vault are packaged in one Capital Industries, Inc. 5-ft $x$ - $\mathrm{ft} \times 9-\mathrm{ft} 7 \mathrm{~A}$, Type A metal box (Part No. S 0600-0600-1080-0104). The 7 columns from the lower vault are packaged in 2 of the Capital Industries, Inc. 5-ft $\times 5-\mathrm{ft} \times 9-\mathrm{ft} 7 \mathrm{~A}$, Type A metal boxes, Part No. S 0600-0600-1080-0104). Three lower vault columns are packaged in one box; four lower vault columns are packaged in the other box. The payload in each box is considered a Type $A$ quantity of radioactive material as defined in 49 CFR 173.433, "Requirements for Determination of $A_{1}$ and $A_{2}$ Values for Radionuclides," and 49 CFR 173.435, "Table of $A_{1}$ and $A_{2}$ Values for Radionuclides." The payload in each box is also fissile exempt (less than 15 grams of fissile material per box as defined in 49 CFR 173.453, "Fissile Materials - Exceptions."

The contents and other data concerning the ion exchange columns are summarized in Table B-1. 
!)d 25 ze pajеш!łsa ndy

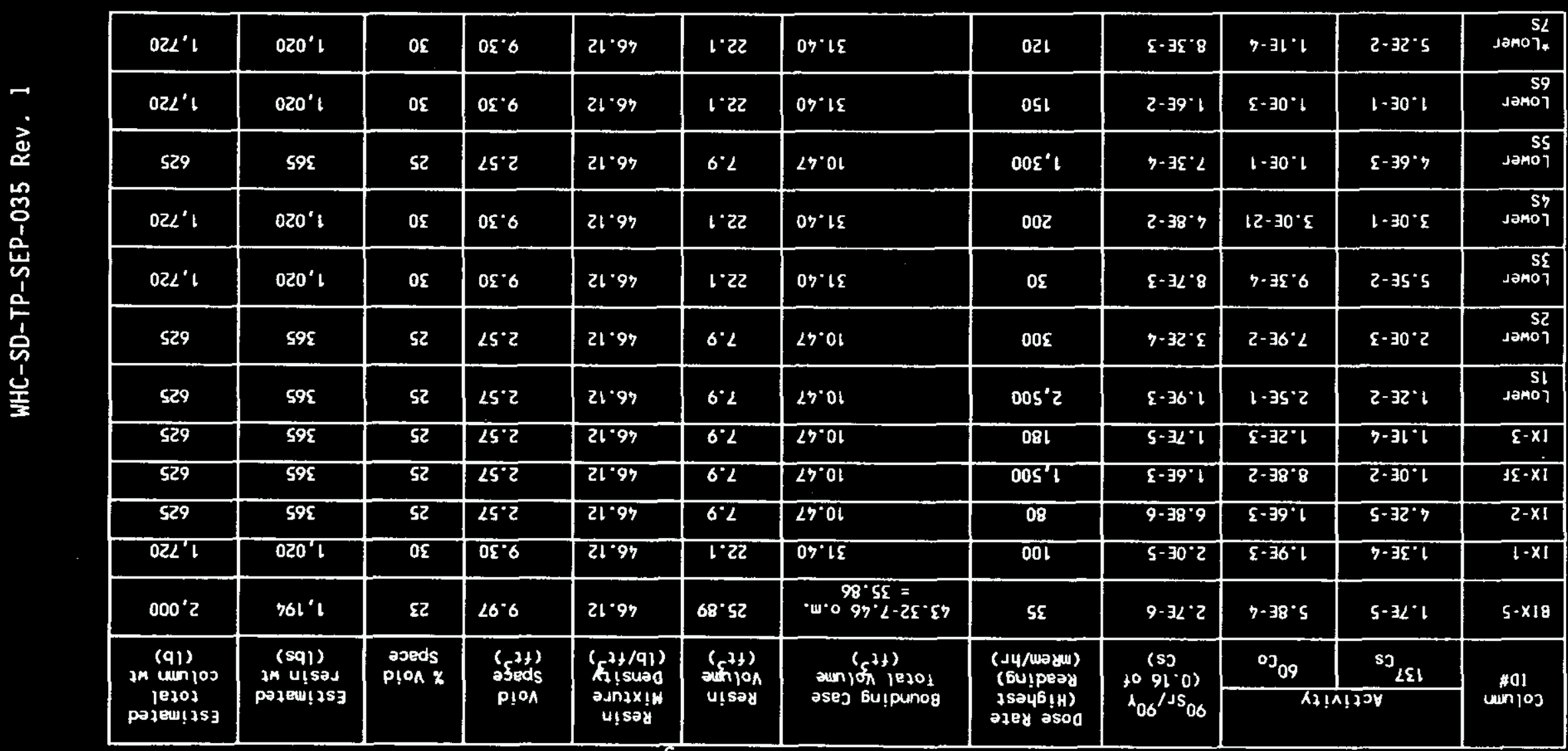

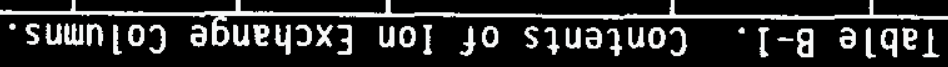




\subsection{CONTENTS DATA AND RESTRICTIONS FOR BOX CONTAINING FIVE UPPER VAULT ION EXCHANGE COLUMNS}

\subsubsection{Source Term}

The following activity is considered the source term ${ }^{2}$

for the metal box containing the five upper vault columns (BIX-5, IX-1, IX-2, IX-3F, IX-3):

$$
\begin{array}{ll}
-{ }^{60} \mathrm{Co} & 0.0937 \mathrm{Ci} \\
-{ }^{137} \mathrm{Cs} & 0.0103 \mathrm{Ci} \\
-{ }^{90} \mathrm{Sr} /{ }^{90} \mathrm{\gamma} & 0.00165 \mathrm{Ci}
\end{array}
$$

The ${ }^{90} \mathrm{Sr} /{ }^{90} \mathrm{Y}$ contribution is based on the results from the resin sample analys is obtained from Sample Analysis 5804 conducted at the 222-S Laboratory. The analysis indicated the following activity in the resin sample:

$$
\begin{array}{ll}
{ }^{90} \mathrm{Sr} & 0.00102 \mu \mathrm{Ci} / \mathrm{g} \\
-{ }^{137} \mathrm{Cs} & 0.00638 \mu \mathrm{Ci} / \mathrm{g} .
\end{array}
$$

The ratio of ${ }^{90} \mathrm{Sr}$ to ${ }^{137} \mathrm{Cs}$ is determined as follows:

$$
\begin{gathered}
(0.00102 \mu \mathrm{Ci} / \mathrm{g}) /(0.00638 \mu \mathrm{Ci} / \mathrm{g})={ }^{137} \mathrm{Cs} \\
0.16 \text { ratio of }{ }^{{ }^{0}} \mathrm{Sr} \text { to }{ }^{2} \mathrm{Cs} \\
(0.0103 \mathrm{Ci}) \times 0.16=0.00165 \mathrm{Ci}{ }^{90} \mathrm{Sr} /{ }^{90} \mathrm{y} \text { contribution. }
\end{gathered}
$$

\subsubsection{Total Activity}

The total activity in the five upper vault columns is considered to meet the activity limits for Type A packages identified in 49 CFR 173.431(a), "Activity Limits for Type A and Type B Packages." This determination is based on calculations for the case of a mixture of different radionuclides, where the identity and activity of each radionuclide is known, in accordance with 49 CFR 173.433(b)(3), "Requirements for Determination of $A_{1}$ and $A_{2}$ Values for Radionuclides." The activity 1 imit for Type $A$ packages is met as indicated in Table B-2.

${ }^{2}$ Non-destructive analys is is recognized to be accurate to two significant figures. However, the source term reported in the analys is was carried out to four, and sometimes five, significant figures. The source term is reported here per analysis. 
WHC-SD-TP-SEP-035 ReV. 1

Table B-2. Activity Limits for Type A Packages.

\begin{tabular}{|c|c|c|c|}
\hline Isotope & Activity & $\begin{array}{c}\text { A2 } \\
\text { Value }\end{array}$ & Ratio of Activity to $A_{2}$ \\
\hline${ }^{60} \mathrm{Co}$ & $0.0937 \mathrm{Ci}$ & 7 & $0.0937 / 7=0.01339$ \\
\hline${ }^{137} \mathrm{Cs}_{\mathrm{S}}$ & $0.0103 \mathrm{Ci}$ & 10 & $0.0103 / 10=0.00103$ \\
\hline $90_{S r} / 90_{Y}$ & $0.00165 \mathrm{Ci}$ & 0.4 & $0.00165 / 0.4=0.00412$ \\
\hline Sun of Fractions & & & $\begin{array}{l}0.013390 .00103+0.00412=0.01854 \\
\text { which is }<1 \text {, therefore Type A }\end{array}$ \\
\hline
\end{tabular}

\subsubsection{Waste Category}

The columns and associated waste are considered Category 1 LLW based on the activity in the metal box vs the activity limits found in WHC-EP-0063, Hanford Site Solid Waste Acceptance Criteria, Section 3, Table 3-1. The determination of Category, 1 is calculated in Table B-3, given that $\left(225 \mathrm{ft}^{3} /\right.$ box $) \mathrm{x}$ $\left(1 \mathrm{~m}^{3} / 35.3 \mathrm{ft}^{3}\right)=6.37 \mathrm{~m}^{3} /$ box.

Table B-3. Determination of Category 1 Waste.

\begin{tabular}{|c|c|c|c|}
\hline Isotope & $\begin{array}{l}\text { Activity per } \\
\text { isotope }\end{array}$ & $\begin{array}{l}\text { Activity timit } \\
\text { (Category } 1 \text { ) }\end{array}$ & Calculation \\
\hline${ }^{60} \mathrm{Co}$ & $0.0937 \mathrm{Ci}$ & $77 \mathrm{ci} / \mathrm{m}^{3}$ & $\begin{array}{l}0.0937 \mathrm{Ci} / 6.37 \mathrm{~m}^{3}=0.0147 \\
\mathrm{Ci} / \mathrm{m}^{3}, 0.0147 / 77=0.0001\end{array}$ \\
\hline${ }^{137} \mathrm{cs}$ & $0.0103 \mathrm{Ci}$ & $0.0063 \mathrm{ci} / \mathrm{m}^{3}$ & $\begin{array}{l}0.0103 \mathrm{ci} / 6 \mathrm{~s}^{37} \mathrm{~m}^{3}= \\
0.0016 \mathrm{ci} / \mathrm{m}^{3}, 0.0016 / 0.0063= \\
0.2539\end{array}$ \\
\hline${ }^{90}{ }_{S r} / 90$ & $0.00165 \mathrm{Ci}$ & $0.0043 \mathrm{ci}^{3} \mathrm{~m}^{3}$ & $\begin{array}{l}0.00165 \mathrm{ci} / 6.37 \mathrm{~m}^{3}=0.00026 \\
\mathrm{ci} / \mathrm{m}^{3}, 0.00026 / 0.0043=0.060\end{array}$ \\
\hline $\begin{array}{l}\text { Sum of Fractions } \\
\text { per WHC-EP-0063, } \\
\text { Apperdix K, } \\
\text { Sect ion K.1.4.1 }\end{array}$ & & & $\begin{array}{l}0.0001+0.2539+0.60=0.854 \\
\text { which is }<1 \text {, therefore } \\
\text { Category } 1\end{array}$ \\
\hline
\end{tabular}

\subsubsection{Dimensions}

The dimensions of the upper five vault columns are shown in Table B-4. 
Table B-4. Dimensions of Upper Vault Columns.

\begin{tabular}{|l|c|c|c|c|}
\hline $\begin{array}{c}\text { Column } \\
\text { Identification } \\
\text { (al1 LLW) }\end{array}$ & $\begin{array}{c}\text { Weight } \\
\text { (Ib) }\end{array}$ & $\begin{array}{c}\text { Diameter } \\
\text { (in.) }\end{array}$ & Length & $\begin{array}{c}\text { Volume } \\
\text { (bounding } \\
\text { case) }\end{array}$ \\
\hline BIX-5 & 2,000 & 34 & $7^{\prime} 4^{\prime \prime}$ & $43.32 \mathrm{ft}^{3}$ \\
\hline IX-1 & 1,720 & 30 & $6^{\prime} 5^{\prime \prime}$ & $30.68 \mathrm{ft}^{3}$ \\
\hline IX-2 & 625 & 18 & $6^{\prime} 3^{\prime \prime}$ & $11.04 \mathrm{ft}^{3}$ \\
\hline IX-3 & 625 & 18 & $6^{\prime} 3^{\prime \prime}$ & $11.04 \mathrm{ft}^{3}$ \\
\hline 5th 18-in. column & 625 & 18 & $6^{\prime} 3^{\prime \prime}$ & $11.04 \mathrm{ft}^{3}$ \\
\hline
\end{tabular}

\subsubsection{Total Volume}

The total volume of the metal box and contents used for packaging the five upper vault columns is based on the volume of the empty metal box, the volume of the columns, the expected void space within the columns (nominally 27.3 percent of the void space in the columns), and the volume of the Pyro foam and miscellaneous waste used to fill the void space between the columns and the metal box. The Pyro foam and miscellaneous waste from column removal operations (i.e., legs cut from columns, gloves, plastic, etc.) has a weight density of approximately $10 \mathrm{lb} / \mathrm{ft}^{3}$.

The total volume calculated for the box containing the five upper vault columns is shown in Table B-5.

Table B-5. Volume Calculations for Upper Vault Column Packaging.

\begin{tabular}{|l|c|c|}
\hline \multicolumn{1}{|c|}{ Volume of } & Calculation & Total $\left(\mathrm{ft}^{3)}\right.$ \\
\hline Empty metal box & - & 225 \\
\hline Columns & $\begin{array}{r}43.32 \mathrm{ft}^{3}+31.40 \mathrm{ft}^{3}+ \\
\left(10.47 \mathrm{ft}^{3} \times 3\right)\end{array}$ & 106.13 \\
\hline Void space & $\begin{array}{r}\left(106.13 \mathrm{ft}^{3}-7.460 . \mathrm{m} \text {. of } 34-\mathrm{in} .\right. \\
\text { column }) \times 27.3 \%\end{array}$ & 26.93 \\
\hline Pyro foam/miscel laneous waste & $225 \mathrm{ft}^{3}-106.13 \mathrm{ft}^{3}-26.93 \mathrm{ft}^{3}$ & 91.94 \\
\hline
\end{tabular}

\subsubsection{Gross Weight}

The gross weight of the five packaged columns is based on the tare weight of one metal box, the weight of the columns, and the weight of the Pyro foam and miscellaneous waste multiplied by the Pyro foam and miscellaneous waste volume, and a bounding case contingency factor for extra weight. The gross weight of the five packaged columns is calculated as shown in Table B-6. 
WHC-SD-TP-SEP-035 Rev. 1

Table B-6. Gross Weight Calculations.

\begin{tabular}{|l|c|c|}
\hline \multicolumn{1}{|c|}{ Meight } & Calculations & lb \\
\hline Metal box (tare) & - & $\begin{array}{c}1,620 \text { per Part No. } \\
\text { 0600-0600-1080-0104 }\end{array}$ \\
\hline Colums (total) & $2,000+9,720+(625 \times 3)$ & 5,595 \\
\hline $\begin{array}{l}\text { Pyro foam and } \\
\text { miscellaneous waste } \\
\text { (total) }\end{array}$ & $91.94 \mathrm{ft}^{3} \times 10 \mathrm{lbs} / \mathrm{ft}^{3}$ & 919 \\
\hline $\begin{array}{l}\text { Cont ingency factor } \\
\text { (bounding case) }\end{array}$ & & 96 \\
\hline Total (bounding case) & & 8,230 \\
\hline
\end{tabular}

\subsection{CONTENTS DATA AND RESTRICTIONS FOR METAL BOX CONTAINING THREE LOWER VAULT COLUMNS}

\subsubsection{Source Term}

Two 18-in. diameter columns and one 30-in. diameter column (Lower 1S, Lower 2S, Lower 3S) from the lower vault are packaged in one 5-ft by $5-\mathrm{ft}$ by $9-\mathrm{ft} 7 \mathrm{~A}$, Type A metal box. The source term ${ }^{3}$ for the box containing these columns is as follows:

$\begin{array}{ll}{ }^{60} \mathrm{Co} & 0.32730 \mathrm{Ci} \\ -{ }^{137} \mathrm{Cs} & 0.06837 \mathrm{Ci} \\ { }^{90} \mathrm{Sr} /{ }^{90} \mathrm{\gamma} & 0.01094 \mathrm{Ci} .\end{array}$

The ${ }^{90} \mathrm{Sr} /{ }^{90} \mathrm{Y}$ contribution is based on the results from the resin sample analysis obtained from Sample Analysis 5804 conducted at the 222-S Laboratory. The analysis indicated the following activity:

$$
\begin{array}{ll}
{ }^{90} \mathrm{Sr} & 0.00102 \mu \mathrm{Ci} / \mathrm{g} \\
{ }^{137} \mathrm{Cs} & 0.00638 \mu \mathrm{Ci} / \mathrm{g} .
\end{array}
$$

The ratio of ${ }^{90} \mathrm{Sr}$ to ${ }^{137} \mathrm{Cs}$ is determined using the following calculation:

$(0.00102 \mu \mathrm{Ci} / \mathrm{g}) /(0.00638 \mu \mathrm{Ci} / \mathrm{g})=0.16$ ratio of ${ }^{90} \mathrm{Sr}$ to ${ }^{137} \mathrm{Cs}$

$\left(0.06837^{137} \mathrm{Cs}\right) \times 0.16=0.01094 \mathrm{Ci}$

\subsubsection{Total Activity}

The total activity within this box is considered to meet the activity 1 imits for Type A packaging listed in 49 CFR 173.431(a), "Activity Limits for Type A and

${ }^{3}$ Non-destructive analysis is recognized to be accurate to two significant figures. However, the source term reported in the analys is was carried out to four, and sometimes five, significant figures. The source term is reported here per analysis.

$$
\text { B2-6 }
$$


WHC-SD-TP-SEP-035 Rev. 1

Type B Packages." This determination is based on calculations for a case of a mixture of different radionuclides where the identity and activity of each radionuclide is known, as outlined in 49 CFR $173.433(\mathrm{~b})(3)$. The activity limits for Type A packages are met as shown in Table B-7.

Table B-7. Activity Limits for Type A Packages.

\begin{tabular}{|l|c|c|c|}
\hline \multicolumn{1}{|c|}{ Isotope } & $\begin{array}{c}\text { Activity } \\
\text { (Ci) }\end{array}$ & $\begin{array}{c}\text { A2 } \\
\text { Value }\end{array}$ & \multicolumn{1}{|c|}{ Ratio of Activity to A2 } \\
\hline${ }^{60} \mathrm{Co}$ & 0.32730 & 7 & $0.32730 / 7=0.046757$ \\
\hline${ }^{137} \mathrm{Cs}$ & 0.06837 & 10 & $0.06837 / 10=0.006837$ \\
\hline${ }^{90} \mathrm{Sr} /{ }^{90} \mathrm{Y}$ & 0.01094 & 0.4 & $0.01094 / 0.4=0.02735$ \\
\hline $\begin{array}{l}\text { Sum of } \\
\text { Fractions }\end{array}$ & & $\begin{array}{l}0.046757+0.006837+0.02735=0.080944 \\
\text { which is <1, therefore Type } \mathrm{A}\end{array}$ \\
\hline
\end{tabular}

\subsubsection{Waste Category}

The columns are considered Category $3 \mathrm{LLW}$ based on the activity in the metai box vs the activity limits found in WHC-EP-0063, Section 3, Table 3-1. The determination of Category 3 is calculated in Table B-8, given that $\left(225 \mathrm{ft}^{3} /\right.$ box $)$ $x\left(1 \mathrm{~m}^{3} / 35.3 \mathrm{ft}^{3}\right)=6.37 \mathrm{~m}^{3} /$ box .

Table B-8. Category 3 Determination.

\begin{tabular}{|c|c|c|c|c|c|}
\hline Isotope & $\begin{array}{l}\text { Activity per } \\
\text { Isotope (Ci) }\end{array}$ & $\begin{array}{l}\text { Activity limit } \\
\text { (Category 1) }\end{array}$ & $\begin{array}{l}\text { Activity limit } \\
\text { (Category 3) }\end{array}$ & $\begin{array}{l}\text { Calculation } \\
\text { (Category 1) }\end{array}$ & $\begin{array}{l}\text { Calculation } \\
\text { (Category 3) }\end{array}$ \\
\hline${ }^{60} \mathrm{CO}$ & 0.32730 & $77 \mathrm{ci} / \mathrm{m}^{3}$ & (6) & $\begin{array}{c}0.32730 \mathrm{ci} / 6.37 \mathrm{~s}^{3} \\
=0.051138 \mathrm{ci} / \mathrm{m}^{3} \\
0.05138877= \\
0.00066\end{array}$ & 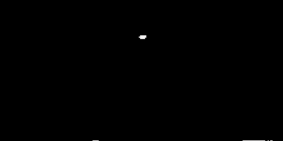 \\
\hline $137 \mathrm{cs}$ & 0.06837 & $0.0063 \mathrm{ci} / \mathrm{m}^{3}$ & $13,000 \mathrm{ci} / \mathrm{m}^{3}$ & $\begin{array}{c}0.06837 \mathrm{ci} / 6.37 \mathrm{~m}^{3} \\
=9.01073 \\
\mathrm{ci} / \mathrm{m}^{3}, 0.01073 / \\
0.0063=1.70\end{array}$ & $\begin{array}{l}0.01073 / 13,000 \\
=0.0000008\end{array}$ \\
\hline${ }^{90} \mathrm{Sr} / 90_{\mathrm{Y}}$ & 0.01094 & $0.0043 \mathrm{ci} / \mathrm{m}^{3}$ & $15,000 \mathrm{ci} / \mathrm{m}^{3}$ & $\begin{array}{c}0.01094 \mathrm{Ci} / 6.37 \mathrm{~m}^{3} \\
=30.001717 \\
\mathrm{Ci} / \mathrm{m}^{\circ} 0.001717 / \\
0.0043=0.39930\end{array}$ & $\begin{array}{c}0.001717 / 15,000 \\
0.0000001\end{array}=$ \\
\hline $\begin{array}{l}\text { Sum of } \\
\text { fractions }\end{array}$ & & & & $\begin{array}{c}0.00066+1.70+ \\
0.39930=2.09996 \\
\text { which is }>1 \\
\text { therefore not } \\
\text { Category } 1\end{array}$ & $\begin{array}{c}0.0000008+ \\
0.0000001= \\
0.0000009 \text { which is } \\
<1 \text {, therefore } \\
\text { Category } 3\end{array}$ \\
\hline
\end{tabular}

\subsubsection{Dimensions}

The dimensions of the three lower vault columns in this metal box are shown in Table B-9. 
WHC-SD-TP-SEP-035 Rev. 1

Table B-9. Dimensions of Three Lower Vault Columns.

\begin{tabular}{|l|c|c|c|c|}
\hline $\begin{array}{c}\text { Column } \\
\text { Ident ification }\end{array}$ & $\begin{array}{c}\text { Weight } \\
\text { (1b) }\end{array}$ & $\begin{array}{c}\text { Diameter } \\
\text { (in.) }\end{array}$ & Length & $\begin{array}{c}\text { Volume (ft }{ }^{3} \text { ) } \\
\text { (bounding case) }\end{array}$ \\
\hline Lower 1S & 625 & 18 & $6^{\prime} 3^{\prime \prime}$ & 10.47 \\
\hline Lower 2S & 625 & 18 & $6^{\prime} 3^{\prime \prime}$ & 10.47 \\
\hline Lower 3S & 1,720 & 30 & $6^{\prime} 5^{\prime \prime}$ & 31.40 \\
\hline
\end{tabular}

\subsubsection{Total Volume}

The total volume of the metal box and contents used for packaging these three columns is based on the volume of the empty metal box, the volume of the columns, the expected void space within the columns (nominally 27.6 percent of the volume in the columns), and the volume of the grout used to fill the void space between the columns and the metal box. The weight density of the grout is $118 \mathrm{lb} / \mathrm{ft}^{3}$. The grout is used to stabilize the columns within the metal boxes to meet the 300-year high-integrity container (HIC) requirement for Category 3 low-level waste (LLW), meeting the requirements of HS-V-P-0036, High Integrity Container, 300 Year.

The total volume calculated for the box containing the three lower vault columns is found in Table B-10.

Table B-10. Three Lower Vault Column Volume Calculations.

\begin{tabular}{|l|c|c|}
\hline \multicolumn{1}{|c|}{ Volume of } & Calculation & Total $\left(\mathrm{ft}^{3}\right)$ \\
\hline Empty metal box & - & 225 \\
\hline Columns & $\left(10.47 \mathrm{ft}^{3} \times 2\right)+31.40 \mathrm{ft}^{3}$ & 52.34 \\
\hline Void Space & $52.34 \mathrm{ft}^{3} \times 27.6 \%$ & 14.44 \\
\hline Grout & $225 \mathrm{ft}^{3}-52.34 \mathrm{ft}^{3}-14.44 \mathrm{ft}^{3}$ & 158.22 \\
\hline
\end{tabular}

\subsubsection{Gross Weight}

The gross weight of the three packaged columns in this box is based on the tare weight of one empty metal box, the weight of the columns, and the weight of the grout multiplied by the volume of grout needed to fill the void space between the columns and the interior walls of the metal box and a bounding-case contingency factor for extra weight. The calculations for determining the gross weight of the packaged columns are shown in Table B-11. 
Table B-11. Gross Weight Calculations.

\begin{tabular}{|l|c|c|}
\hline \multicolumn{1}{|c|}{ Weight of: } & Calculations & $1 \mathrm{~b}$ \\
\hline Box (tare) & - & $1,620^{1}$ \\
\hline Columns & $\begin{array}{c}1,720 \mathrm{lbs}+(625 \mathrm{lb} \times \\
2\end{array}$ & 2,970 \\
\hline Grout & $158.22 \mathrm{ft}^{3} \times 118 \mathrm{lb} / \mathrm{ft}^{3}$ & 18,670 \\
\hline $\begin{array}{l}\text { Contingency factor } \\
\text { (bounding case) }\end{array}$ & - & 1,640 \\
\hline Total (bounding case) & & 24,900 \\
\hline
\end{tabular}

'Defined for Part No. S 0600-0600-1080-0104.

\subsection{CONTENTS DATA AND RESTRICTIONS FOR METAL BOX CONTAINING FOUR LOWER VAULT COLUMNS}

\subsubsection{Source Term}

The following activity is considered the source term ${ }^{4}$ for the metal box containing the four lower vault ion exchange columns (Lower $4 S$, Lower $5 S$, Lower $6 \mathrm{~S}$, Lower $7 \mathrm{~S}$ ) based on non-destructive analysis:

$\begin{array}{ll}-{ }^{60} \mathrm{Co} & 0.13322 \mathrm{Ci} \\ -{ }^{137} \mathrm{Cs} & 0.45689 \mathrm{Ci} \\ -{ }^{239} \mathrm{Pu} & 2.0 \mathrm{pC} \\ -{ }^{90} \mathrm{Sr} /{ }^{90} \mathrm{Y} & 0.07310 \mathrm{Ci}\end{array}$

The ${ }^{90} \mathrm{Sr} /{ }^{90} \mathrm{Y}$ contribution is based on the results from the resin sample analys is obtained from Sample Analysis 5804 conducted at the 222-S Laboratory. The analysis indicated the following activity in the res in sample:

$\begin{array}{ll}{ }^{90} \mathrm{Sr} & 0.00102 \mu \mathrm{Ci} / \mathrm{g} \\ { }^{137} \mathrm{Cs} & 0.00638 \mu \mathrm{Ci} / \mathrm{g} .\end{array}$

The ratio of ${ }^{90} \mathrm{Sr}$ to ${ }^{137} \mathrm{Cs}$ is determined as follows:

$$
\begin{gathered}
(0.00102 \mu \mathrm{Ci} / \mathrm{g}) /(0.00638 \mu \mathrm{Ci} / \mathrm{g})=0.16 \mathrm{ratio} \text { of }{ }^{90} \mathrm{Sr} \text { to }{ }^{137} \mathrm{CS} \\
0.45689 \mathrm{Ci} \mathrm{CS} \times 0.16=0.07310{ }^{90} \mathrm{Sr} /{ }^{90} \mathrm{Y} \text { contribution. }
\end{gathered}
$$

"Non-destructive analysis is recognized to be accurate to two significant figures. However, the source term reported in the analysis was carried out to four, and sometimes five, significant figures. The source term is reported here per analysis. 


\subsubsection{Total Activity}

The total activity within this box is considered to meet the activity 7 imits for Type A packaging in accordance with 49 CFR 173.431(a), "Activity Limits for Type A and Type B Packages." This determination is based on calculations for a case with a mixture of different radionuclides where the identity and activity of each radionuclide is known, as described in 49 CFR $173.433(\mathrm{~b})(3)$. The activity limits for Type $A$ packages are met as shown in Table B-12.

Table B-12. Type A Packaging Activity Limits.

\begin{tabular}{|l|c|c|c|}
\hline \multicolumn{1}{|c|}{ Isotope } & Activity & A2 Value & Ratio of activity to A2 \\
\hline${ }^{239} \mathrm{Pu}$ & $2.0 \mathrm{pCi}$ & 0.002 & $2.0 \mathrm{pCi} / 0.002=0.00000001$ \\
\hline${ }^{60} \mathrm{Co}$ & $0.13322 \mathrm{Ci}$ & 7 & $0.13322 / 7=0.019031$ \\
\hline${ }^{137} \mathrm{Cs}$ & 0.45689 & 10 & $0.45689 / 10=0.045689$ \\
\hline${ }^{90} \mathrm{Sr} /{ }^{90} \mathrm{Y}$ & 0.07310 & 0.4 & $0.07310 / 0.4=0.18275$ \\
\hline $\begin{array}{l}\text { Sum of } \\
\text { Fractions }\end{array}$ & & & $\begin{array}{l}0.00000001+0.019031+0.045689+ \\
0.18275=0.24747 \text { which is }<1, \\
\text { therefore Type A }\end{array}$ \\
\hline
\end{tabular}

\subsubsection{Waste Category}

The columns are considered Category 3 LLW based on the activity in the columns vs the activity limits found in WHC-EP-0063, Hanford site Solid Waste Acceptance Criteria, Section 3 , Table $3-1$. Given that $\left(225 \mathrm{ft}^{3} / \mathrm{box}\right) \times\left(1 \mathrm{~m}^{3} / 35.3\right.$ $\left.\mathrm{ft}^{3}\right)=6.37 \mathrm{~m}^{3} /$ box, the Category 3 determiniation is calculated as shown in Table B-13. 
WHC-SD-TP-SEP-035 Rev. 1

Table B-13. Calculations for Category 3 Determination.

\begin{tabular}{|c|c|c|c|c|c|}
\hline I sotope & $\begin{array}{l}\text { Activity per } \\
\text { Isotope }\end{array}$ & $\begin{array}{c}\text { Activity I imit } \\
\text { (Category 1) }\end{array}$ & $\begin{array}{c}\text { Activity limit } \\
\text { (Category 3) }\end{array}$ & $\begin{array}{c}\text { Calculation } \\
\text { (Category 1) }\end{array}$ & $\begin{array}{c}\text { Calculat i on } \\
\text { (Category } 3 \text { ) }\end{array}$ \\
\hline${ }^{239} \mathrm{Pu}$ & $2.0 \mathrm{pCi}$ & $0.0036 \mathrm{ci} / \mathrm{m}^{3}$ & $0.77 \mathrm{ci} / \mathrm{m}^{3}$ & 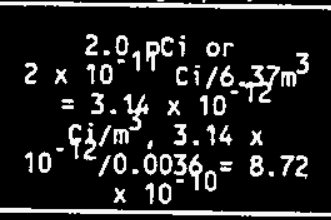 & $\begin{array}{c}3.14 \times 10^{-12}, \\
0.77=f^{0} \times \\
10^{-1}\end{array}$ \\
\hline${ }^{60} \mathrm{CO}$ & $0.13322 \mathrm{Ci}$ & $77 \mathrm{ci} / \mathrm{m}^{3}$ & & $\begin{array}{c}0.13322 \mathrm{ci} \\
6.3 \mathrm{~m}^{3}=0.020913 \\
\mathrm{ci} / \mathrm{m}^{3} 0.020913 / 77= \\
0.00027\end{array}$ & - \\
\hline${ }^{137} \mathrm{cs}$ & $0.45689 \mathrm{Ci}$ & $0.0063 \mathrm{ci} / \mathrm{m}^{3}$ & $13,000 \mathrm{ci} / \mathrm{m}^{3}$ & $\begin{array}{c}0.45689 \mathrm{ci} / \\
6.37 \mathrm{~m}=\mathrm{m} \cdot 07172 \\
\mathrm{ci} / \mathrm{m} \cdot \\
0.017172 / 0.0063= \\
11.3849\end{array}$ & $\begin{array}{l}0.07172 / 13,000 \\
=0.00007\end{array}$ \\
\hline${ }^{90} \mathrm{Sr} /^{90 \mathrm{Y}}$ & $0.07310 \mathrm{Ci}$ & $0.0043 \mathrm{ci} / \mathrm{m}^{3}$ & $15,000 \mathrm{ci} / \mathrm{m}^{3}$ & $\begin{array}{c}0.07310 \mathrm{ci} / 6.37 \mathrm{~m}^{3}= \\
0.011476 \mathrm{ci} / \mathrm{m}^{3} \\
0.011476 / \\
0.0043=2.66883\end{array}$ & $\begin{array}{c}0.011476 / 15,000 \\
=0.0000008\end{array}$ \\
\hline $\begin{array}{l}\text { Sum of } \\
\text { Fractions }\end{array}$ & & & & $\begin{array}{c}8.72 \times 10.10+ \\
0.00027+11.3849+ \\
2.66883=14 \text {, which } \\
\text { is }>1 \text {, therefore not } \\
\text { Category } 1\end{array}$ & $\begin{array}{c}10^{-12} .0 \times \\
+0.0000000= \\
0.000071 \text {, which } \\
\text { is <1, } \\
\text { therefore } \\
\text { Category } 3 \\
\end{array}$ \\
\hline
\end{tabular}

\subsubsection{Dimensions}

The dimensions of the four columns in this box are shown in Table B-14.

Table B-14. Dimensions of Four Lower Vault Columns.

\begin{tabular}{|l|c|c|c|c|}
\hline $\begin{array}{c}\text { Column } \\
\text { identification }\end{array}$ & $\begin{array}{c}\text { Weight } \\
\text { (lb) }\end{array}$ & $\begin{array}{c}\text { Diameter } \\
\text { (in.) }\end{array}$ & Length & $\begin{array}{c}\text { Volume ( } \mathrm{ft}^{3} \text { ) } \\
\text { (bounding case) }\end{array}$ \\
\hline Lower 4S & 1,720 & 30 & $6^{\prime} 5^{\prime \prime}$ & 31.40 \\
\hline Lower 5S & 625 & 18 & $6^{\prime} 3^{\prime \prime}$ & 10.47 \\
\hline Lower 6S & 1,720 & 30 & $6^{\prime} 5^{\prime \prime}$ & 31.40 \\
\hline Lower 7S & 1,720 & 30 & $6^{\prime} 5^{\prime \prime}$ & 31.40 \\
\hline
\end{tabular}

\subsubsection{Total Volume}

The total volume of the metal box and contents used for packaging the four columns is based on the volume of the empty metal box, the volume of the columns, the expected void space (nominally 29.4 percent of the volume in the columns), and the volume of the grout used to fill the void space between the columns and the inside walls of the metal box. The weight density of the grout is $118 \mathrm{lb} / \mathrm{ft}^{3}$. The grout is used to stabilize the columns within the metal box to 
meet the 300-year HIC requirement found in Specification HS-V-P-0036. The calculations for total volume of the box containing the four lower vault columns is shown in Table B-15.

Table B-15. Volume of Lower Vault Columns.

\begin{tabular}{|l|c|c|}
\hline \multicolumn{1}{|c|}{ Volume of: } & Calculation & $\begin{array}{c}\text { Total } \\
\left(\mathrm{ft}^{3}\right)\end{array}$ \\
\hline Empty box & - & 225 \\
\hline Columns & $\left(31.40 \mathrm{ft}^{3} \times 3\right)+10.47 \mathrm{ft}^{3}$ & 104.67 \\
\hline Void Space & $104.67 \mathrm{ft}^{3} \times 29.4 \%$ & 30.77 \\
\hline Grout & $225 \mathrm{ft}^{3}-104.67 \mathrm{ft}^{3}-30.77 \mathrm{ft}^{3}$ & 89.56 \\
\hline
\end{tabular}

\subsubsection{Gross Weight}

The gross weight of the four packaged columns in this box is also based on the tare weight of one empty metal box, the weight of the columns, and the weight of the grout multiplied by the volume of grout needed to fill the void space between the columns and the interior walls of the metal box, and a bounding case contingency factor for extra weight. The gross weight of the metal box containing the four columns is shown in Table B-16.

Table B-16. Gross Weight of Metal Box with Four Columns.

\begin{tabular}{|l|c|c|}
\hline \multicolumn{1}{|c|}{ Weight of: } & Calculations & $1 \mathrm{~b}$ \\
\hline Metal box (tare) & - & 1,620 \\
\hline Columns & $(1,7201 \mathrm{~b} \times 3)+6251 \mathrm{~b}$ & 5,785 \\
\hline Grout (tota) & $89.56 \mathrm{ft}^{3} \times 1181 \mathrm{~b} / \mathrm{ft}^{3}$ & 10,568 \\
\hline $\begin{array}{l}\text { Contingency factor (bounding } \\
\text { case) }\end{array}$ & - & 3,727 \\
\hline Total (bounding case) & & 21,700 \\
\hline
\end{tabular}

${ }^{1}$ Per Part No. S 0600-0600-1080-0104.

\subsection{CONCLUSIONS}

In conclusion, the contents of the metal boxes as described are acceptable for packaging and transfer. The radioactive contents in the payload meets the limitations for Type A packaging as set forth in 49 CFR 173.433 and 49 CFR 173.435. The overweight conditions of the loaded boxes are acceptable as addressed in Part B, Sections 3.0 and 5.0. The dose rates encountered are deemed acceptable based on Part B, Section 4.0. Heat and hydrogen generation are not a concern with these payloads, as discussed in Part B, Sections 6.0 and 7.0. Criticality is not a concern because the payload meets the fissile exempt definition of 49 CFR 173.453, "Fissile Material - Exceptions." 
WHC-SD-TP-SEP-035 Rev. 1

B2-13 


\subsection{CONTAINMENT EVALUATION}

\subsection{INTROOUCTION}

The purpose of this evaluation is to demonstrate that the metal boxes packaged in accordance with Part B, Section 2.0 will maintain their contents under normal conditions of transport.

\subsection{CONTAINMENT SOURCE SPECIFICATION}

The following is the gamma, beta, and alpha contribution for each of the three boxes when packed with the ion exchange columns.

r One box will contain five ion exchange columns from the upper vault. The box also will contain miscellaneous waste and Pyro foam to fill the void space. The box will contain $0.0937 \mathrm{Ci}{ }^{60} \mathrm{Co}, 0.0101 \mathrm{Ci}{ }^{137} \mathrm{Cs}$, and $0.00165 \mathrm{Ci}{ }^{90} \mathrm{Sr} /{ }^{90} \mathrm{Y}$. The box will weigh at most $8,2301 \mathrm{~b}$.

- A second box will contain three ion exchange columns from the lower vault. The void space inside the box will be filled with grout. The box will contain $0.32730 \mathrm{Ci}{ }^{60} \mathrm{Co}, 0.06837 \mathrm{Ci}{ }^{137} \mathrm{Cs}$, and $0.01094 \mathrm{Ci}$ ${ }^{90} \mathrm{Sr} /{ }^{90} \mathrm{Y}$. The box will weigh at most $24,900 \mathrm{lb}$.

c A third box will contain four ion exchange columns from the lower vault. The void space inside the box will be filled with grout. The box will contain $0.13322 \mathrm{Ci}{ }^{60} \mathrm{Co}, 0.45689 \mathrm{Ci}{ }^{137} \mathrm{Cs}, 2.0 \mathrm{pCi}{ }^{239} \mathrm{Pu}$, and $0.07310 \mathrm{Ci}{ }^{90} \mathrm{Sr} /{ }^{90} \mathrm{Y}$. The box will weigh at most $21,700 \mathrm{lb}$.

The payloads in the boxes are considered LLW. No neutron sources are considered to be present. The payloads also are considered Type $A$, as indicated in Part B, Section 2.0. Because the quantity is Type $A$, an analys is of hypothetical accident conditions is not required.

\subsection{NORMAL TRANSFER CONDITIONS}

The boxes must maintain their respective payloads (see Part B, Section 2.0) under normal conditions of transport, which are described in 10 CFR 71.71.

The packaged ion exchange columns were analyzed using a drop scenario. Additional scenarios that were analyzed were filling the boxes with material to eliminate void space and lifting the boxes.

As indicated in Part B, Section 5.0, a worst case scenario of a horizontal drop on a compact soil and gravel surface was evaluated. Results of the evaluation indicate that a box filled with ion exchange columns and grout will withstand a normal-condition drop without buck)ing or excessive deformation (see Appendix B-1). However, to achieve this result, the grout must be cured. See Part B, Appendix B-1.

As indicated in Part B, Section 5.4, when filling the void spaces of the box with grout, the boxes must be shored to ensure that the sheet metal walls and bottom are supported during the grouting process. Shoring is required because 
the 10 gauge sheet metal walls and 12 gauge sheet metal bottom will not withstand the hydrostatic load of uncured grout without buckling and yield failure.

The lifting evaluation of the box assumes that the worst case strap angle for lifting is $60^{\circ}$ from horizontal. The evaluation results (see Part B, Section 5.4 ) show that the box can be 1 ifted with acceptable margins of safety at angles of $60^{\circ}$ or greater from horizontal. However, the grout must be cured for at least 7 days because the package does not have sufficient strength to support the load of uncured grout.

\subsection{CONTAINMENT EVALUATION CONCLUSIONS}

As indicated in Part B, Section 5.4, the box containment is acceptable for loading, lifting, and transport under the following conditions:

- The metal boxes are properly shored during the Pyro foam and grout filling process.

- The Pyro foam is fully reacted and the grout is cured for a minimum of 7 days before lifting and transporting the boxes. 
WHC-SD-TP-SEP-035 Rev. 1

\subsection{SHIELDING EVALUATION}

\subsection{INTRODUCTION}

The purpose of this evaluation is to ensure that the packaging (metal box) and the position of each package on the trailer affords adequate shielding during normal conditions of transport.

\subsection{DIRECT RADIATION SOURCE SPECIFICATION}

The following is the gamma, beta, and alpha contribution for each of the three boxes when packaged with ion exchange columns:

- One box will contain five ion exchange columns from the upper vault. Miscellaneous waste and Pyro foam will be used to fill the void space inside the box. The box will contain $0.0937 \mathrm{Ci}{ }^{60} \mathrm{Co}, 0.0101 \mathrm{Ci}{ }^{137} \mathrm{Cs}$ and $0.00165 \mathrm{Ci}{ }^{90} \mathrm{Sr} /{ }^{90} \mathrm{Y}$. The box will weigh at most $8,230 \mathrm{1b}$.

- A second box will contain three ion exchange columns from the lower vault. Grout will be used to fill void space inside the box. The box will contain $0.32730 \mathrm{Ci}{ }^{60} \mathrm{Co}, 0.06837 \mathrm{Cj}{ }^{137} \mathrm{Cs}$ and $0.01094 \mathrm{Ci}{ }^{90} \mathrm{Sr} /{ }^{90} \mathrm{Y}$. The box will weigh at most 24,900 1b.

- A third box will contain four ion exchange columns from the lower vault. Grout will be used to fill the void space inside the box. The box will contain $0.13322 \mathrm{Ci}{ }^{60} \mathrm{Co}, 0.45689 \mathrm{Ci}{ }^{137} \mathrm{Cs}, 2.0 \mathrm{pCi}{ }^{239} \mathrm{Pu}$, and $0.07310 \mathrm{Ci}{ }^{90} \mathrm{Sr} /{ }^{90} \mathrm{Y}$. The box will weigh at most $21,700 \mathrm{lb}$.

The payloads within the boxes are considered LLW. No neutron sources are considered to be present.

\subsection{SUMMARY OF SHIELDING PROPERTIES OF MATERIAL}

The metal boxes provide little shielding from radiation other than that afforded by their metal walls.

\subsection{NORMAL TRANSFER CONDITIONS}

Dose rates on the surface of the metal boxes were evaluated based on survey readings from the surface of each fully loaded metal box. Survey readings were evaluated against $U$. S. Department of Transportation (DOT) radiation level limitations. The DOT prescribes the following radiation level limitations for shipment of radioactive material in accordance with 49 CFR 173.441, "Radiation Level Limitations":

- A radiation level limit of $200 \mathrm{mRem} / \mathrm{hr}$ at the surface of any package shipped via open transport vehicle.

- A radiation level 1 imit of $10 \mathrm{mRem} / \mathrm{hr}$ at any point $2 \mathrm{~m}$ from the outer lateral surface of the vehicle. 
WHC-SD-TP-SEP-035 Rev. 1

- A radiation level limit of $2 \mathrm{mRem} / \mathrm{hr}$ in any normally occupied space (i.e., cab of the tractor).

These 1 imitations must be met during onsite transfers of radioactive material at the Hanford Site, unless they cannot be met safely and economically, taking into account the shielding capability and design of the package, the type of transport vehicle used, and the principles of ALARA.

If these limitations cannot be met, equivalent safety to the DOT radiation level limitations must be achieved through approved administrative controls and principles of ALARA (i.e., time of exposure to the source, distance from the source, and shielding against the source).

\subsection{SHIELDING EVALUATION AND CONCLUSIONS}

Survey readings indicate that the surface dose rate readings of the boxes exceed DOT limitations ( $400 \mathrm{mRem} / \mathrm{hr}$ at the surface of the package) prescribed in Part B, Section 4.4. Survey readings at $1 \mathrm{~m}$ from the 1 inear side of each box (including top and bottom) will not exceed the contact dose rate for any given side of all three boxes loaded together.

Attempting to shield the inner walls of the boxes or reposition the ion exchange columns in the boxes is contrary to ALARA principles. Therefore, if possible, configuring the boxes (if two or more boxes are loaded together) on the trailer used for transfer such that the lowest dose rate readings are exposed to the outside of the trailer is acceptable as an administrative control and method of shielding. No additional shielding is required regardless of box configuration on the trailer.

Exclusion of non-essential workers and the public at the time of transport (see Part A, Section 4.3) provides distance from the source of radiation resulting in dose rates received at contact with the surfaces of the boxes. Exclusion also provides distance from the source of radiation resulting in dose rates received at $2 \mathrm{~m}$ from the vertical planes projected by the outer edges of the vehicle (excluding the top and undersides of the vehicle).

The 2-mRem/hr limit at the tractor cab is achieved by the configuration of the boxes on the trailer and the distance between the cab of the tractor and the nearest box (see Part A, Section 4.3). No additional shielding is required for this transfer.

Based on the source term in the boxes, the configuration of the ion exchange columns in the boxes (i.e., ion exchange columns, Pyro foam, and miscellaneous waste; ion exchange columns and grout), the configuration of the boxes on the trailer(s), and the known dose rate readings at contact with the boxes (see Appendix B-1), no additional shielding analys is is required. 
WHC-SD-TP-SEP-035 Rev. I

APPENDIX B-1

309 BUILDING TANK FARM

$B A-1$ 
WHC-SD-TP-SEP-035 Rev. 1

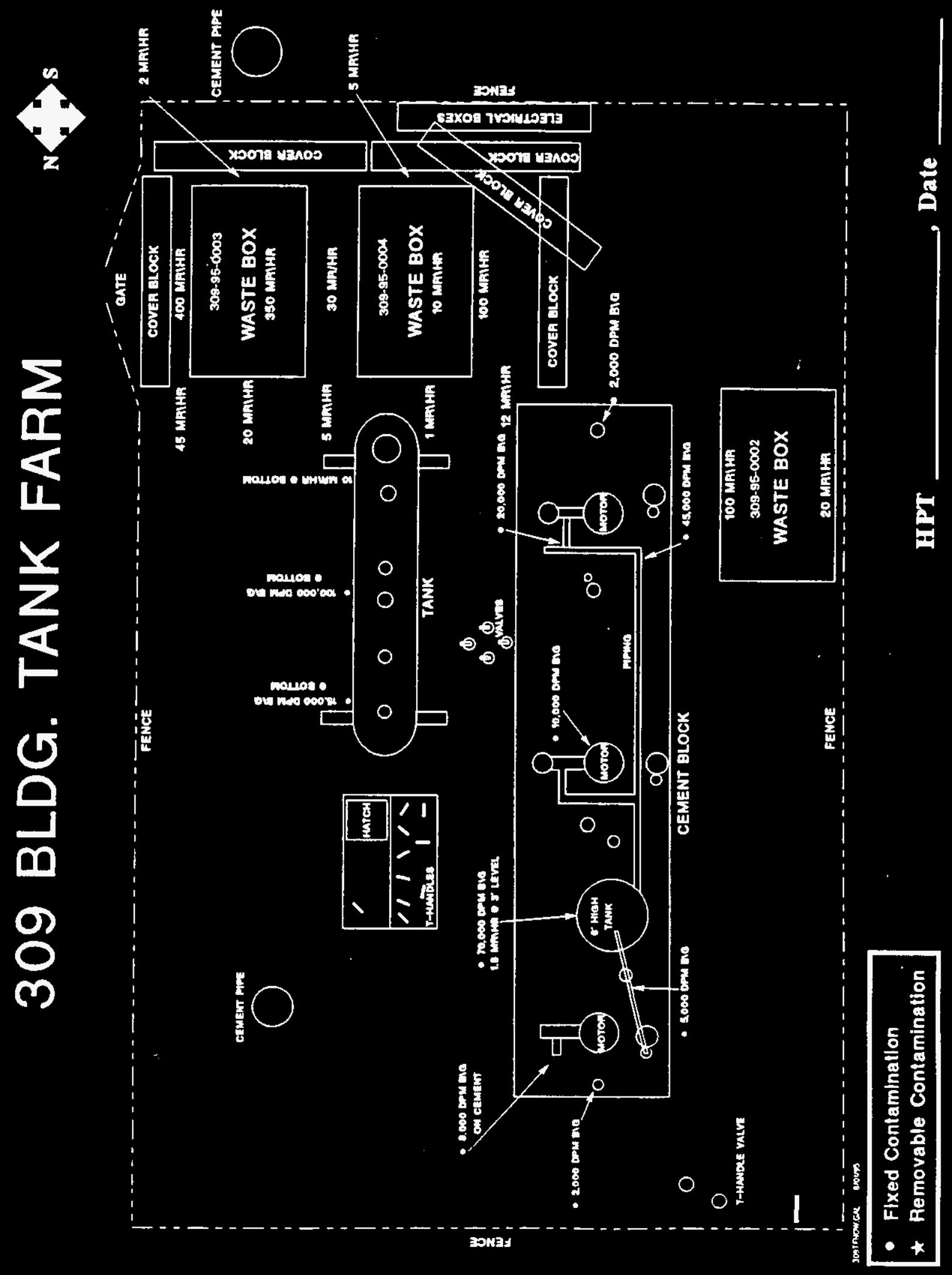




\subsection{STRUCTURAL EVALUATION}

\subsection{INTRODUCTION}

This evaluation will determine the structural capabilities of the metal boxes for transport of Type $A$ quantities of radioactive material. In addition, it will show that the boxes will be safe for transport while being loaded beyond the rated capacity of the box.

\subsection{STRUCTURAL EVALUATION OF PACKAgE}

\subsubsection{Structural Design and Features Offered by the Metal Boxes}

Specifications for the metal box used to package the ion exchange columns are as follows.

- Overall dimensions: 66 in. wide, 63-1/4 in. deep, 114-3/4 in. long

- Interior dimension: $60 \mathrm{in}$. wide, $60 \mathrm{in.} \mathrm{deep,} 108 \mathrm{in.}$ long

- Number of corrugations: 24

- Materials of construction:

- 10-gauge bottom, 12-gauge 1 id and sides, A570 hot rolled sheet steel, and A36 structural members and 3/16-in. thick plate

- Lid reinforcing: Angle 3 in. $x 7 / 16$ in. $x 3 / 16$ in., around 1 id perimeter

- Lid seal: 2-in. wide, 1/4-in. thick, commercial 30 durometer neoprene

- Lid fasteners: $1 / 2$ in. - $13 \times 1-1 / 2$-in. stainless steel bolts and nuts

- Design and Fabrication Methods

- The boxes used to package the ion exchange columns are welded metal boxes designed in accordance with Capital Industries, Inc. Specification S 0600-0600-1080-0104.

$\begin{array}{lr}\text { Total Weight } & 1,6201 \mathrm{~b} \\ \text { Weight, box } & 1,2451 \mathrm{~b} \\ \text { Weight, lid and stiff } & 3751 \mathrm{~b} \\ \text { Certified weight } & 7,0001 \mathrm{~b} \\ \text { Maximum gross weight } & 24,9001 \mathrm{~b} .\end{array}$

- Volume (Cavity size) $225.0 \mathrm{ft}^{3}$, (60 in. $x 60$ in. $x 108 \mathrm{in.)}$

- Containment Boundary: the containment boundary is the top (including 
neoprene lid seal), bottom, and sides of the box containing ion exchange columns, Pyro foam, and miscellaneous waste. The containment boundary for the boxes containing ion exchange columns and grout is the top layer of solidified grout and the sides and bottom of the box. The lid (top) of these boxes is excluded.

- Heat Dissipation: The payload generates a low enough level of heat (less than 1 watt per box) that passive cooling is all that is required.

\subsubsection{Chemical and Galvanic Reactions}

No chemical or galvanic reactions will affect the ability of the metal boxes to maintain the payloads identified in Part B, Section 2.0.

\subsubsection{Lifting and Tiedown Devices}

Not applicable. The boxes will be "saddled" using nylon slings because of the overweight conditions of the fully loaded metal boxes.

\subsubsection{Positive Closure}

The lid fasteners, which are $1 / 2$ in. $-13 \times 1-1 / 2-i n$. stainless steel bolts and nuts. There is no positive closure mechanism required for the boxes containing grout.

\subsubsection{Weights and Center of Gravity}

The weight of the packaged columns is assumed to be at the geometric center of the box.

\subsubsection{Lifting and Tiedown Devices}

Not applicable. The boxes will be "saddled" using nylon slings because of the overweight conditions of the fully loaded metal boxes.

\subsection{NORMAL TRANSFER CONDITIONS}

Within this evaluation, the ability of the metal boxes to maintain their contents under normal conditions of transport is analyzed using the worst case loading for a normal-condition drop, grout fill, and lifting of the box. In addition, the boxes were analyzed with the lids removed (see Appendix B-2).

\subsection{STRUCTURAL EVALUATION AND CONCLUSIONS}

The loaded metal boxes consist of the same type of metal box with three different maximum payload weights (i.e., 8,230 1b, 21,700 1b, and 24,900 1b). One box contains Category I LLW and therefore requires only Pyro foam as the 
void-space filler. This box has a maximum gross weight of $8,2301 \mathrm{~b}$. The other two boxes contain Category 3 LLW that requires stabilization of the waste with grout. The addition of grout to the payload substantially increases the weight of the loaded boxes $(21,700 \mathrm{lb}$ and $24,900 \mathrm{lb}$, respectively).

The orientation and surface of the drop was chosen as a horizontal drop on a compact soil and gravel surface. Evaluation of the drop indicates that the box will withstand a normal-condition drop without buckling or excessive deformation, even with the lids removed from the boxes containing grout. (See Part B, Appendix B-2 for analysis of this drop.)

As indicated in Part B, Appendix B-2, when filling the void spaces of the box with grout, the box must be shored to ensure that the sheet metal walls and bottom are supported during the grouting process. Shoring is required because the 10-gauge sheet metal wa11s and 12-gauge sheet metal bottom will not withstand the hydrostatic load of uncured grout without buckling and yield failure.

The lifting evaluation of the box assumes that the worst case strap angle for lifting is $60^{\circ}$ from horizontal. The evaluation results (see Part $B$, Appendix B-2) show that the box can be safely lifted with acceptable margins of safety at angles of $60^{\circ}$ or greater from horizontal. However, the grout must be cured for at least 7 days because the package does not have sufficient strength to support the load of uncured grout.

In conclusion, safe handling and transport of the boxes is dependent on:

- Properly shoring the boxes during Pyro foam and grout filling operations - The Pyro foam is fully reacted before lifting and transporting the
boxes

- The grout is cured for a minimum of 7 days before lifting and transporting the boxes. 
II T⿱ 
WHC-SD-TP-SEP-035 Rev. I

APPENDIX B-2

SHIRAGA ENGINEERING SAFETY EVALUATION

BB-1 
ENOWEERINC SAFETY EVALUATION

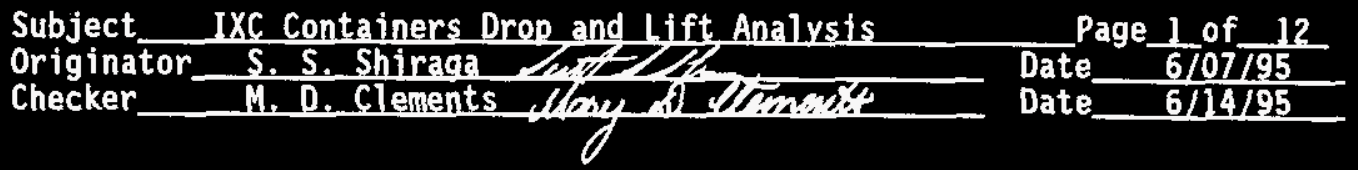

\section{Obiective:}

The objective of this analysis is to determine the structural capabilities of the IXC metal box containers for transport of Type A quantities of materials. The metal boxes, DOT Specification 7A, Type A containers. However, in this appi ication the boxes are loaded beyond the rated capacity. Subsequently, this evaluation is to show that despite being over loaded, the containers remain safe for transport.

II. Reference:

1) Capital Industries, Inc., Drawing Number S 0600-0600-1080-0104, Shipping Container-DOT SpeC $7 A$, Type A.

2) Burnside, M. E., cc:Mail to S. S. Shiraga, re: IXC Box Weights, June 1, 1995.

3) Rinehart, J. S., and Pearson, J., Behavior of Metals Under Impulsive Loads, American Society for Metals, Cleveland, Ohio, 1954.

4) Young, W. C., Roark's Formulas for Stress and Strain, McGraw-Hi11, New York, New York, 1989.

5) Timoshenko, S. and Woinowsky-Krieger, S., Theory of Plates and Shells, McGrawHi11, New York, New York, 1959.

III. Resuits and Conclusions:

There are three types of packages. The packages consist of the same container loaded with three different payload weights and grout filling. Within this evaluation, the worst case loading is evaluated for normal condition drop, grout fill and lifting. All the evaluations are based on classic linear elastic methods augmented by free body diagrams.

Results of the normal condition drop shows that in the three drop conditions the loading is approximately the same. Subsequently, the highest dynamically loaded case was chosen for the normal condition drop evaluation. The orientation and surface of drop for this evaluation was chosen as a flat horizontal drop onto a compact soil and gravel surface. Evaluation of the highest dynamic load shows that the package will withstand a normal condition drop without buckling or excessive deformation. However, in all cases the grout must be fully cured.

The container is modeled as vertical panels subjected to the deceleration loading of the lid. The panels are evaluated by comparing the critical buckling load versus the decelerated load of the lid. The U-Channels at the bottom of the container are evaluated as beams on an elastic foundation loaded by the full dynamic load of the package. 


ENGINEERING SAFETY EVALUATION
Subject IXC Containers Dropand Lift Analysis
Originator S.S. Shiraga
Checker

Evaluation results of grout filling shows that the sheet metal walls and bottom package must be shored. Without proper support, the 10 gauge sheet metal walls and 12 gauge sheet metal bottom will not withstand the hydrostatic load of the uncured grout. Lack of support results in bucking and yield failure of the sheet metal.

Grout fill loadings are modeled by assuming the bottom and walls are flat uniform plates. The bottom is assumed to be uniformly loaded and simpiy supported on all sides, the walls are assumed to be loaded by fluid pressure and simply supported on three sides and free on the other. Results of the evaluation shows the plates experience large deflections, consequently the ultimate load capacity of the plates is determined. These calculations show that the bottom and walls are loaded beyond their load carrying capacity when the grout is in its fluid stage. Consequently, during grout fill the containers must be properly shored to provide adequate support.

The lifting evaluation of the package assumes that the worst case strap angle for lifting is $60^{\circ}$ from horizontal. The evaluation results show that the package can be safely lifted with acceptable margins of safety at lift angles of $60^{\circ}$ or greater from the horizontal. The evaluation assumes the grout is fully cured and has a strength of 2,000 psi. This is required, since the packaging does not have sufficient strength to support the loaded of uncured grout and must rely on the strength and rigidity of the cured grout for safe lifting operations.

Consequently, safe handling and transport of the package is dependent upon two primary factors. First the container must properly supported during grout void filling operations. Also, the grout must be fully cured prior to package lifting and transport. 


Subject IXC Containers Drop and Lift Analysis
Originator S.S. Shiraga

\section{Enginaering Evaluation:}

Assume a $2 \mathrm{ft}, 3 \mathrm{ft}$ and $4 \mathrm{ft}$ flat horizontal drop on sand and gravel for nomal conditions of transport. Also assume container design is the same for all three containers.

Weights and drop heights of containers (M. E. Burnside, Calculations): $i=1 . .3$

$\begin{array}{llll}\text { Container \#1: } & W c_{1}=8,230 \mathrm{lb} & \text { Drop height: } & \mathrm{H}_{1}=4 \mathrm{ft} \\ \text { Container \#2: } & {W c_{2}}=24,900 \mathrm{lb} & \text { Drop height: } & \mathrm{H}_{2}=2 \mathrm{ft} \\ \text { Container \#3: } & {W c_{3}}=21,700 \mathrm{lb} & \text { Drop height: } & \mathrm{H}_{3}=3 \mathrm{ft}\end{array}$

Weight of container lid: $\quad \mathrm{w}_{1 \mathrm{dd}}=380 \mathrm{lb}$

Empty container weight: $W_{\text {cont }}=1,2451 b+w_{11 d}$

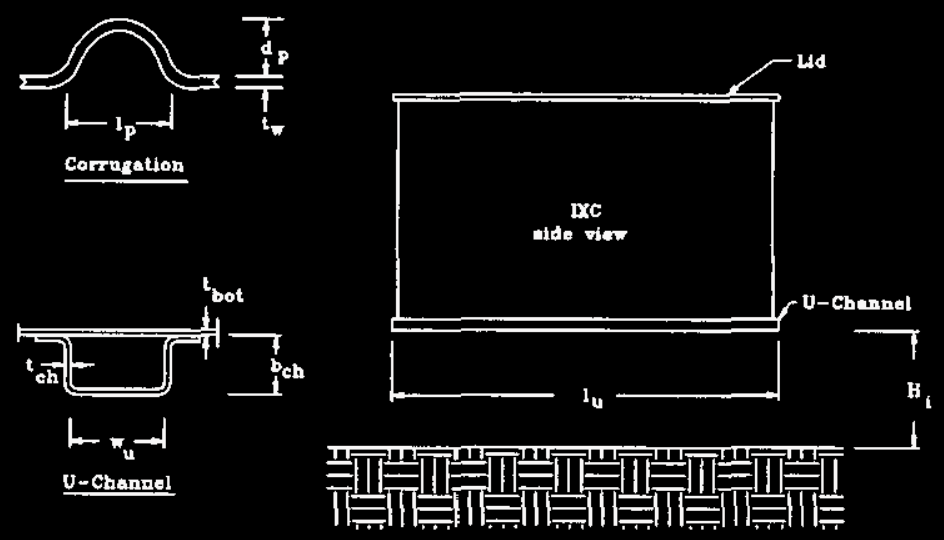

Determine "g" loading from enpirical equations and data developed by Rinehart and Pearson in "Behavior of Metais Under Impuls ive Loads."

Impact area of container is on 5 U-channels located at bottom of container:

Impact length: $l_{u}=64$ in Imact width: $w_{u}=5.5$ in

$$
A_{u_{2}}=51_{u} w_{u}
$$


Subject Originato IXC containars Drop and Ift Analysis Checker

s. S. Shirada

M. D. Clenents

Material parameters for impact on sand and gravel (Rinehart and Pearson):

$$
a_{e g}=620 \mathrm{psi} \quad b_{e g}=0.0115 \frac{1 \mathrm{~b}-\mathrm{sec}^{2}}{\mathrm{ft}^{2} \mathrm{in}^{2}}
$$

Energies of drop: $\quad \mathbf{E}_{1}=\hbar c_{1} \mathrm{H}_{1}$

$$
E_{1}=32,9201 b-f t \quad E_{2}=49,8001 b-f t \quad E_{3}=65,1001 b-f t
$$

Velocity of impact: $\quad v_{1}=\sqrt{2 g H_{1}}$

$$
v_{1}=16.04 \mathrm{ft}_{-\mathrm{sec}^{-1}} \quad v_{2}=11.34 \mathrm{ft}-\mathrm{sec}^{-1} \quad v_{3}=13.89{\mathrm{ft}-\mathrm{sec}^{-1}}^{-1}
$$

Depth of penetration into soil, (Rinehart and Pearson, Behavior of Metals Under Impulsive Load):

$$
\begin{aligned}
& \delta d_{1}=\frac{W C_{1}}{2 g b_{g g} A_{v g}} \ln \left[1+\left(\frac{b_{g q}}{a_{\alpha g}}\right)\left(V_{1}\right)^{2}\right] \\
& \delta d_{1}=0.36 \text { in } \quad \delta d_{2}=0.55 \text { in } \quad \delta d_{3}=0.71 \text { in }
\end{aligned}
$$

Force transmitted to package: $\quad F d_{1}=\frac{E_{1}}{\delta d_{1}}$

$$
F d_{1}=1,094,0001 \mathrm{~b} \quad \mathrm{Fd}_{2}=1,093,000 \mathrm{lb} \quad \mathrm{Fd}_{3}=1,093,0001 \mathrm{~b}
$$

Resultant "g" loading: $\quad \operatorname{gdec}_{i}=\frac{F d_{i}}{W c_{1}}$

$$
\text { gdec }_{1}=132.9 \quad \text { gdec }_{2}=43.88 \quad \text { gdec }_{3}=50.38
$$

Evaluate buckling for highest "g" load

Assume grout does not bond to container. Therefore loading from lid on side walls of container.

Wall thickness of container: $t_{\text {wall }}=0.104$ in 12 gauge material. 


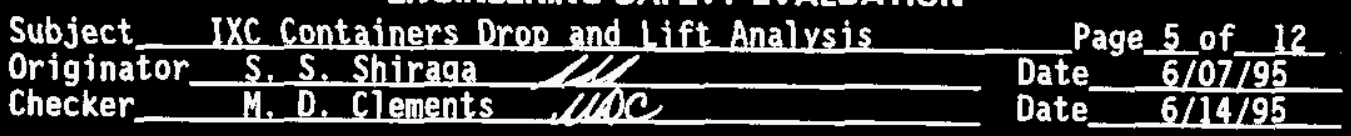

Effective length of walls bearing load, including corrugations:

Assume corrugations are parabolic.

Height: $d_{p}=1.25$ in Width: $\quad l_{p}=1.6875$ in

Length of arc of each corrugation:

$$
s_{p}=\frac{1}{2} \sqrt{16 d_{p}^{2}+I_{p}^{2}}+\frac{l_{p}^{2}}{8 d_{p}} \ln \left(\frac{4 d_{p}+\sqrt{16 d_{p}^{2}+I_{p}^{2}}}{I_{p}}\right) \quad s_{p}=3.15 \text { in }
$$

Number of corrugations: $\quad n_{\text {coxx }}=24$

Length of wall without corrugations:

$$
1_{\text {mal1 }}=4\left(30.1 \text { in }-21_{p}+1.25 \text { in }\right)+2\left(108 \text { in }-81_{p}\right)
$$

Total length of walls: $\quad l_{\text {tot }}=l_{\mathrm{wall}}+n_{\mathrm{cox} x} \mathrm{~s}_{\mathrm{p}} \quad l_{\mathrm{tot}}=377$ in

Compressive load on walls: $p_{\text {mall }}=\frac{\text { gdec }_{1} w_{11 d}}{I_{\text {tot }} t_{\text {wall }}} \quad P_{\text {wall }}=1,290$ psi

Assume each section between corrugations is a panel. Treat panel as simply supported on the edges by the corrugations and pinned at top and bottom. Determine critical loading, for a wide column, for the widest section.

Widest pane] section: $\quad b_{\text {pan }}=18$ in $-l_{p}$

Height of simply supported edges: $\quad h_{p}=59.8125$ in

Ratio for buckling pattern: $\quad \mathrm{m}=\frac{\mathrm{h}_{\mathrm{p}}}{\mathrm{b}_{\mathrm{pan}}} \quad \mathrm{m}=3.67$

Constant: $\quad k=\left(\frac{h_{p}}{m b_{p a n}}+\frac{m b_{p a n}}{h_{p}}\right)^{2} \quad k=4$

Critical buckling stress on panel (Roark, 6th Edition):

Assumed modulus of elasticity: $\quad E_{\text {cut } 1}=29,600,000$ psi 


Subject IXC Containers Drop and Lift Analysis
Originator S.S. Shiraga

Assume Poisson's ratio: $\quad v_{\text {cat1 }}=0.3$

$$
\sigma_{c x}=\frac{\pi^{2} k E_{c a t 1}}{12\left(1-v_{c a t 1}{ }^{2}\right)}\left(\frac{t_{\operatorname{mall}}}{b_{\operatorname{pan}}}\right)^{2} \quad \sigma_{c z}=4,350 \mathrm{psi}
$$

Margin of safety: $\quad \mathrm{MS}_{\mathrm{cx}}=\frac{\sigma_{\mathrm{cx}}}{\mathrm{P}_{\mathrm{wa11}}}-1 \quad \mathrm{MS}_{\mathrm{cx}}=2.37$ or

\section{Evaluate loading on U-channel:}

Load on botton supports:

Assume uniform distribution of load from heaviest load. Load distributed on 5 bottom supports.

Load per support: $\quad F_{\frac{1}{}}=\frac{F \mathrm{~d}_{i}}{5} \quad F_{q}=218,761 \mathrm{lb}$

Treat as a bean on elastic foundation.

Model flat drop as a beam on an elastic foundation:

Assume drop, use as an elastic foundation (Roark, 6th Edition):

Length of support: $\quad 1=1_{u}$

Foundation modulus (Timoshenko, Theory of Shells and Plates): $\quad k_{\mathrm{grav}}=750 \mathrm{psi}$

Channel dimensions: $d_{c h}=5.5$ in $\quad b_{c h}=1.875$ in $t_{c h}=0.1875$ in

$$
a_{c h}=b_{c b}-t_{c h}
$$

Distance to the center of gravity: $\quad x_{b c h}=\frac{\frac{d_{c h} t_{c h}{ }^{2}}{2}+2\left(a_{c h} t_{c h}\right)\left(t_{c h}+\frac{a_{c h}}{2}\right)}{d_{c h} t_{c h}+2 a_{c h} t_{c h}}$

Moment of inertia: $\quad I_{c h}=\frac{d_{c h} x_{b c h}{ }^{3}-d_{c h}\left(x_{b c h}-t_{c h}\right)^{3}+2 t_{c h}\left(b_{c h}-x_{b c h}\right)^{3}}{3}$

Force per unit length: $\quad F_{10 n}=\frac{F_{\mathbf{q}}}{l}$ 
Cross sectional area of channel: $\quad A_{c h}=t_{c h}\left(d_{c h}+2 b_{c h}\right)$

Loading parameters:

Beam loading location: $\quad a_{1}=0$ in $\quad$ Evaluation location: $\quad x_{1}=\frac{1}{2}$

Foundation factor: $\quad \beta=\left(\frac{k_{\text {grav }}}{4 E_{\text {cati }} I_{c h}}\right)^{\frac{1}{4}}$

Calculational constants:

$C_{11}=\sinh (\beta 1)^{2}-\sin (\beta 1)^{2} \quad C_{2}=\cosh (\beta 1) \sin (\beta 1)+\sinh (\beta 1) \cos (\beta 1)$

$c_{3}=\sinh (\beta 1) \sin (\beta 1) \quad C_{4}=\cosh (\beta 1) \sin (\beta 1)-\sinh (\beta 1) \cos (\beta 1)$

$\mathrm{C}_{\mathrm{a} 2}=\cosh \left[\beta\left(1-\mathrm{a}_{1}\right)\right] \sin \left[\beta\left(1-\mathrm{a}_{1}\right)\right]+\sinh \left[\beta\left(1-\mathrm{a}_{1}\right)\right] \cos \left[\beta\left(1-\mathrm{a}_{1}\right)\right]$

$C_{a 3}=\sinh \left[\beta\left(1-a_{1}\right)\right] \sin \left[\beta\left(1-a_{1}\right)\right] \quad F_{1}=\cosh \left(\beta x_{1}\right) \cos \left(\beta x_{1}\right)$

$F_{2}=\cosh \left(\beta x_{1}\right) \sin \left(\beta x_{1}\right)+\sinh \left(\beta x_{1}\right) \cos \left(\beta x_{1}\right)$

$F_{3}=\sinh \left(\beta x_{1}\right) \sin \left(\beta x_{1}\right) \quad F_{1}=\cosh \left(\beta x_{1}\right) \sin \left(\beta x_{1}\right)-\sinh \left(\beta x_{1}\right) \cos \left(\beta x_{1}\right)$

$F_{a 2}=\cosh \left[\beta\left(x_{1}-a_{1}\right)\right] \sin \left[\beta\left(x_{1}-a_{1}\right)\right]+\sinh \left[\beta\left(x_{1}-a_{1}\right)\right] \cos \left[\beta\left(x_{1}-a_{1}\right)\right]$

$F_{a 3}=\sinh \left[\beta\left(x_{1}-a_{1}\right)\right] \sin \left[\beta\left(x_{1}-a_{1}\right)\right]$

$\theta_{\mathrm{A}}=\frac{F_{10 n}}{2 E_{\text {cat1 } 1} I_{c h} \beta^{3}} \frac{C_{2} C_{a 3}-C_{3} C_{a 2}}{C_{11}} \quad y_{A}=\frac{F_{10 n}}{4 E_{c a t 1} I_{c h} \beta^{4}} \frac{C_{1} C_{a 2}-2 C_{3} C_{a 3}}{C_{11}}$

$R_{\mathbf{A}}=0 \mathrm{lb} \quad \mathrm{M}_{\mathrm{A}}=0 \mathrm{lb}-\mathbf{i n}$

Shear force:

$$
\begin{gathered}
V_{1}=R_{\lambda} F_{1}-y_{\lambda} 2 E_{c a t 1} I_{c h} \beta^{3} F_{2}-\theta_{\lambda} 2 E_{c a t 1} I_{c h} \beta^{2} F_{3}-M_{\lambda} \beta F_{4}-\frac{F_{l e n} F_{A 2}}{2 \beta^{2}\left(1-a_{1}\right)} \\
V_{1}=38,062.8 \mathrm{lb}
\end{gathered}
$$




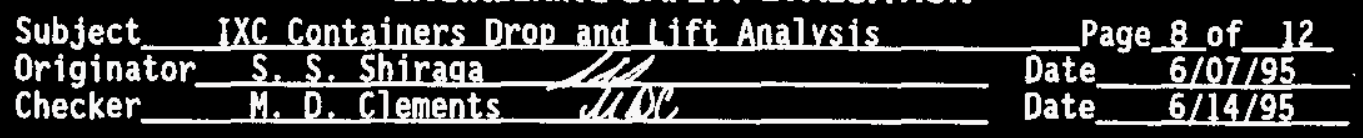

Moment:

$$
M_{1}=M_{\lambda} F_{1}+\frac{R_{\lambda}}{2 \beta} F_{2}-y_{\lambda} 2 E_{c d t 1} I_{c h} \beta^{2} F_{3}-\theta_{\lambda} E_{c a t 1} I_{c h} \beta F_{4}-\frac{F_{10 n} F_{n 3}}{2 \beta^{2}} \quad M_{1}=0 \text { lb-in }
$$

Bending stress: $\quad \sigma_{b a a}=\frac{M_{1} \frac{b_{c h}}{2}}{I_{c b}} \quad \sigma_{b a s}=0$ psi

Maximum shear stress: $\quad \sigma_{\tan }=\frac{V_{1}}{A_{c h}} \quad \sigma_{\varepsilon a n}=26,142 \mathrm{psi}$

ASTM A-36 properties: $\quad s_{\mathrm{yo}}=36,000 \mathrm{psi} \quad s_{\mathrm{uo}}=58,000 \mathrm{psi}$

Dynamic allowable based on static yield and ultimate of A-36 (Reference Crede and Harris):

Value of constant for when some yielding can be tolerated: $\quad C=0.5$

Establish dynamic allowable of yield:

$$
s_{\text {day }}=\frac{2}{3}\left[s_{y o}+C\left(s_{\text {uo }}-s_{y o}\right)\right] \quad s_{\text {day }}=31,333 \mathrm{psi}
$$

Margin of safety: $M S_{u}=\frac{s_{d a y}}{\sigma_{\text {tax }}}-1 \quad M S_{u}=0.2$

Loading due to grout fill operations:

Base evaluation on heaviest load for grout fill operation. Since wet grout has no rigidity, assume the loading is from a amporphous mass with no structural integrity on the bottom of the container until cure.

Density of grout: $P_{\mathrm{gx}}=118 \frac{\mathrm{lb}}{\mathrm{ft}^{3}} \quad$ Volume of container void: $\quad v_{\mathrm{cv}}=138.7 \mathrm{ft}^{3}$

Weight: $\quad w_{g x}=p_{g x} v_{o v} \quad$ Bottom thickness: $t_{b o t}=0.134$ in

Area of bottom: $\quad l_{\text {bot }}=111.5$ in $\quad w_{\text {bot }}=63$ in $\quad A_{\text {bot }}=w_{\text {bot }} l_{\text {bot }}$

Load per unit area on bottom: $p_{b o t}=\frac{W_{g z}}{A_{b o t}} \quad p_{b o t}=2$ psi 


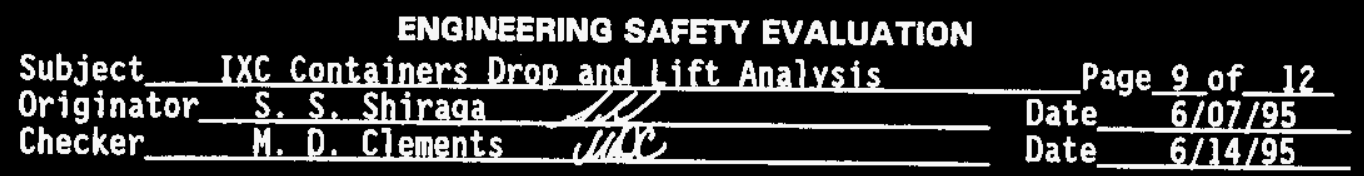
Model section between bottom supports as a rectangular simply supported and uniformly
loaded.

Width of section between supports: $\quad w_{100}=48$ in $-2(7.875$ in)

Length to width ratio: $\quad \frac{l_{\text {bot }}}{w_{\text {coc }}}=3.46$

Deflection of bottom plate: $\quad y_{\text {bot }}=\frac{0.135 p_{b o t} w_{10 c c}^{4}}{E_{c a t 1} t_{b o t}{ }^{3}} \quad y_{b o t}=4.78$ in

Excessive deflection, must determine ultimate capacity of plate.

$$
\begin{aligned}
& \frac{W_{c o c}}{I_{b o t}}=0.29 \quad s_{y}=36,000 \mathrm{psi} \quad W_{u}=7.68 s_{y} t_{b o t}{ }^{2} \quad W_{v}=4,964 \mathrm{lb} \\
& p_{u}=\frac{W_{u}}{l_{b o t} W_{c o c}} \quad p_{u}=1.38 \mathrm{psi}
\end{aligned}
$$

Margin of safety: $\quad \mathrm{MS}_{\mathrm{bot}}=1-\frac{\mathrm{p}_{\mathrm{bot}}}{\mathrm{p}_{\mathrm{u}}} \quad \mathrm{MS}_{\mathrm{bot}}=-0.69 \quad$ 50 coodl

Therefore bottom must be shored when void filling with grout at least between channel sections.

Load on side walls of container:

Density of sand: $\quad P_{g x}=118 \frac{1 b}{f^{3}} \quad p_{g x}=P_{g x} h_{p} \quad p_{g x}=4.08 p s i$

Deflection at bottom of walls: $\quad y_{o w}=\frac{0.069 p_{g z} b_{p a x}{ }^{4}}{E_{c a t 1} t_{w a 11}{ }^{3}} \quad y_{m w}=0.6$ in

Since deflection greater than thickness, determine ultimate capacity:

$$
\frac{p_{g z} b_{p a n}{ }^{4}}{E_{\text {cat1 }} t_{\text {vall }}{ }^{4}}=83.52 \quad \frac{b_{\text {pan }}}{b_{p}}=0.27
$$

Ultimate capacity: $\quad p_{s i d o}=\frac{\frac{\pi}{2} s_{y} t_{\text {mall }}{ }^{2}}{b_{p a n} h_{p}} \quad P_{a i d o}=0.63$ psi 


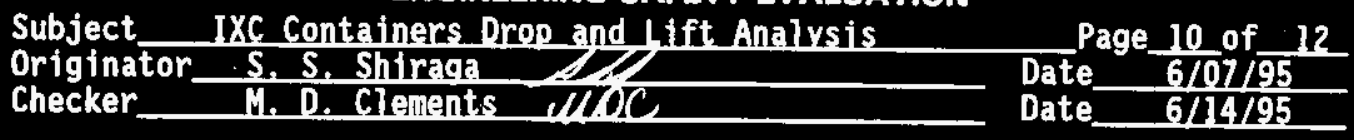

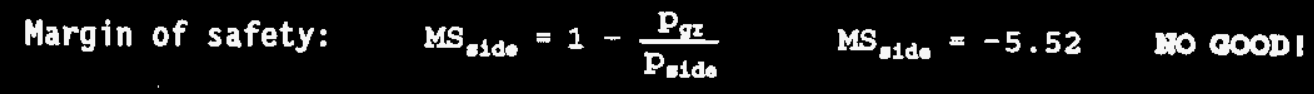

Therefore bottom must be shored when void filling.

\section{Lifting ovaluation:}

Assume lift is done when grout is fully cured, therefore grout bears entire weight of the load. Assume no strength contribution from payload. Assume lift angle at worst case is at $60^{\circ}$ from horizontal and straps are inserted through the channel sections.

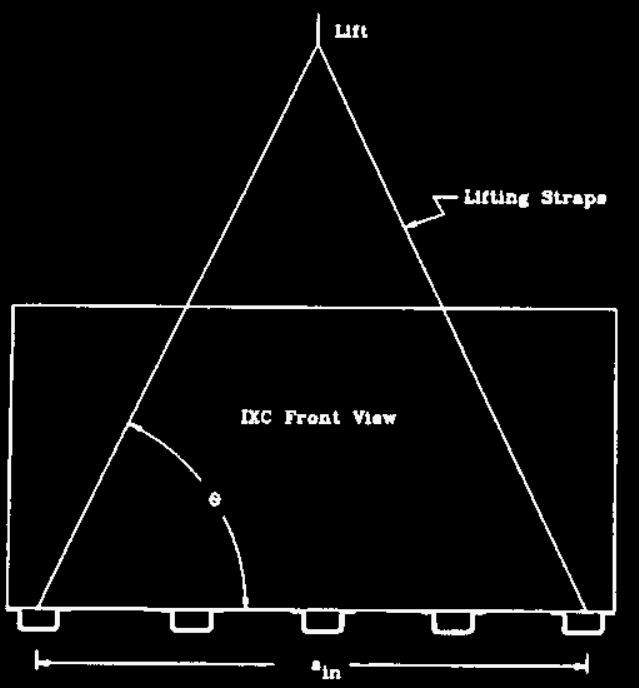

Dimensions of grout block (inside dimensions of container):

$$
\begin{array}{ll}
\text { Length: } & 1_{1 \mathrm{n}}=108 \mathrm{in} \\
\text { Height: } & h_{1 \mathrm{n}}=60 \mathrm{in} \\
\text { Width: } & w_{1 \mathrm{n}}=60 \mathrm{in}
\end{array}
$$

Span of straps:

$$
\begin{gathered}
s_{1 n}=(31.625 \mathrm{in}-27 \mathrm{in})+48 \mathrm{in}+2.27 \mathrm{in} \\
s_{1 n}=106.62 \mathrm{in}
\end{gathered}
$$

Span to depth ratio: $\frac{s_{1 n}}{h_{1 n}}=1.78$

Since ratio < 4, must consider as short bean.

Assume lift angle from horizontal is: $\theta=60 \mathrm{deg}$

Vertical load: $\quad F_{v}=\frac{W c_{2}}{2}$ Tension in leg: $\quad T_{v}=\frac{F_{v}}{\sin (\theta)}$

Horizontal load: $\quad F_{\mathrm{h}}=\mathrm{T}_{\mathrm{v}} \cos (\theta) \quad F_{\mathrm{h}}=7,188 \mathrm{lb}$ 


Subject IXC Containers Drop and Lift Analysis
Originator S, S. Shiraga Page 11 of $\frac{12}{6 / 07 / 95}$
Checker

Model as uniformly loaded simply supported bean.

Assume strength of grout: $\quad f_{g x}=2,000 \mathrm{psi}$

Modulus of elasticity of grout: $E_{g x}=\left(57,000 f_{g x}^{0.5}\right) p^{0.5}$

Moment of inertia of grout block cross section: $\quad I_{g x}=\frac{h_{1 n}}{12}$

Maximum moment at center:

$$
\begin{aligned}
& \text { Loading factor: } \quad k_{1}=\sqrt{\frac{F_{v}}{E_{g x} I_{g x}}} \\
& \qquad K_{\max }=\frac{W C_{2}}{k_{1}^{2} s_{1 n}}\left(\frac{k_{1} s_{\text {in }}}{2 \sin \left(\frac{k_{1} s_{i n}}{2}\right)}-1\right) \quad M_{\max }=110,6241 \mathrm{~b}-\text { in } \\
& \text { Bending stress: } \quad \sigma_{b}=\frac{M_{\max } \frac{h_{\text {in }}}{2}}{I_{g x}} \quad \sigma_{b}=3 \mathrm{psi}
\end{aligned}
$$

Short beam shear stress: $\quad \tau=\frac{W_{c_{2}} h_{1 n}{ }^{2}}{8 I_{g z}} \quad \tau=10 \mathrm{psi}$

Principle stress: $\quad \sigma_{p}=\frac{\sigma_{b}}{2}+\sqrt{\left(\frac{\sigma_{b}}{2}\right)^{2}+\tau^{2}} \quad \sigma_{p}=12 \mathrm{psi}$

Margin of stress: $\quad M S_{g x}=\frac{f_{g z}-1}{\sigma_{p}} \quad M S_{g x}=165.33 \quad$ or

Lateral load on channel welds: $\quad s_{\mathrm{aw}}=13,000 \mathrm{psi} \quad \mathrm{w}_{\mathrm{wold}}=\frac{3}{16}$ in

$$
f_{\text {allow }}=s_{\text {aw }}(0.707) w_{\text {wold }} \quad f_{\text {allow }}=1,723.31 \frac{\mathrm{lb}}{\mathrm{in}}
$$

Amount of weld required: $\quad I_{\mathrm{wreq}}=\frac{F_{\mathrm{b}}}{\mathrm{f}_{\text {allow }}} \quad I_{\mathrm{wreq}}=4.17 \mathrm{in}$ 
WHC-SD-TP-SEP-035 Rev. 1

ENGINEERING SAFETY EVALUATION

Subject IXC Containers Drop and Lift Anaivsis
Originator S. S. Shiraga

Checker.

I. 0.Clements

Page 12 of 12

Date.

$6 / 07 / 95$

- Date

$6 / 14 / 95$

Anount of weld available:

Length of channel: $\quad 1_{\mathrm{ch}}=64$ in $\quad 1_{\text {wold }}=2\left(\frac{1_{c h}-12 \text { in }}{4 \text { in }}\right) 2$ in $\quad 1_{\text {wold }}=52$ in

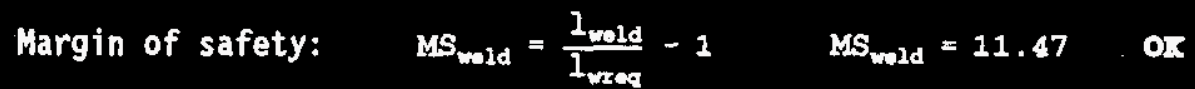

$\mathrm{BB}-13$ 


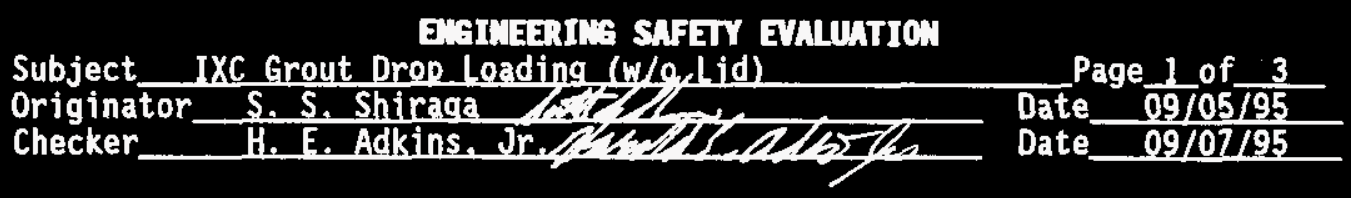

\section{Objectives:}

The objective of this evaluation is determine if the packaging grout will maintain sufficient structural integrity to allow shipment without the lid. The criteria for this evaluation is that the grout must maintain encapsulation of the contents under the normal conditions of transport drop onto asphalt.

II. References:

1) Capital Industries, Inc., Drawing Number S 0600-0600-1080-0104, Shipping Container-DOT Spec 7A, Type A.

2) Burnside, M. E., cc:Mail to S. S. Shiraga, re: IXC Box Weights, June 1, 1995.

3) England, J. L., Internal Memo to M. E. Burnside, Compressive Strength Results, Dated August 22, 1995.

4) ACI, ACI Manual of Concrete Practice, Part 3, American Concrete Institute, Detroit, Michigan, 1989.

5) Den Hartog, J. P., Advanced Strength of Materials, McGraw-Hi11 Book Company, New York, New York, 1952.

III. Results and Conclusions:

Results from this evaluation show that the grout will maintain encapsulation of the contents after a normal conditions of transport drop. In other words, the grout will not fragment or collapse after a normal condition drop.

This evaluation is based on the compressive strength of the grout provided in Reference 3 and the assumption that the grout behaves in the same manner as normal concrete. The evaluation determines the loading on the grout by modeling it as a monolithic plate supported at intervals. The resulting bending stresses from this model show the stresses in the grout do not exceed the strength of the grout. Also, no strength or reinforcing contribution by the payload is considered within the evaluation. 


$\begin{array}{ll}\text { Subject IXC Grout Orog Lading (w/o Lid) } & \text { Page } 2 \text { of } \frac{3}{09 / 05 / 95} \\ \text { Originator S. S. Shiraga } & \text { Date } \\ \text { Checker } & \text { Date }\end{array}$

\section{Enginearing Evaluation:}

Determine if strength of grout is adequate for package to be shipped without the 1 id and maintain encapsulation of the payload under nomal conditions of transport.

Assume all of the deceleration force is applied to grout block.

Deceleration force: $\quad \mathrm{Ed}_{1}=1,094,0001 \mathrm{~b}$

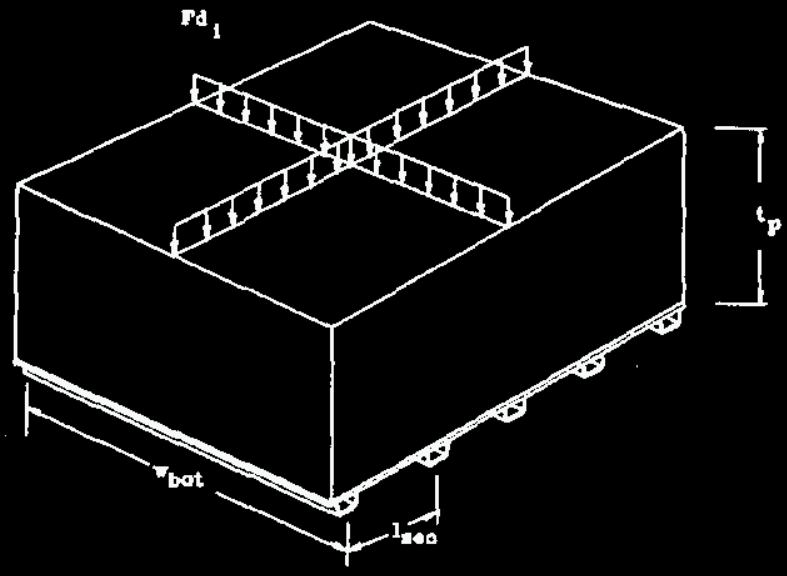

Model as a continuous slab, uniformly Toaded and supported in section. Assume loading is uniform over the entire surface of the block.

Length of entire slab: $\quad I_{\text {bot }}=111.5$ in

Width of slab: $\quad w_{\text {bot }}=63 \mathrm{in}$

Length of section: $\quad l_{\text {wec }}=\frac{l_{\text {bet }}}{4}$

Area of slab: $\quad A_{\text {bot }}=1_{\text {bot }} W_{\text {bot }}$

Compressive load on grout due to deceleration: $\quad p_{\text {comp }}=\frac{F_{1}}{A_{b o t}} \quad p_{c o w p}=156 p s i$

Thickness of slab: $\quad t_{p}=60 \mathrm{in}$

Determine loading per Den Hartog, p. 134, case 25:

Dimensional ratio: $\quad \frac{w_{\text {bet }}}{1_{\text {tec }}}=2.26$ Dimensionless moment factor: $d f_{m}=0.0829$

Dimensionless deflection factor: $\quad d f_{d}=0.032$

Strength of grout: $\quad s_{\text {exout }}=3,200 \mathrm{psi}$ 


Subject IXC Grout Dran Loading (w/o Lid)
Originator S. S. Shiraga
Checker

Modulus of elasticity:

For normal weight concrete (ACI, p. 318/318R-83), concrete modulus of elasticity:

$$
E_{c}=\left(57,000 s_{\text {grout }}{ }^{0.5}\right) p 81^{0.5}
$$

Maximum moment at center:

$$
\begin{aligned}
& \text { Moment: } \quad M_{t}=d f_{p} p_{c o m p} W_{\text {bot }}{ }^{2} \quad M_{t}=51,243 \mathrm{lb} \\
& \text { Deflection: } \quad \delta_{p}=d f_{d} \frac{p_{c o f} w_{b o t}}{E_{c} t_{p}{ }^{3}} \quad \delta_{p}=0.0001 \text { in }
\end{aligned}
$$

Since deflection is significantly less than $40 \%$ of the thickness, small deflection theory still applies.

$$
\begin{array}{ll}
\text { Bending stress in plate: } \quad \sigma_{b}=6 \frac{M_{t}}{t_{p}^{2}} & \sigma_{b}=85 \text { psi } \\
\text { Margin of safety: } \quad \text { MS }=\frac{s_{\text {grout }}}{\sigma_{b}}-1 \quad \text { MS }=36.47
\end{array}
$$

Therefore grout will not fail under a normal condition drop onto asphalt. 


\subsection{THERMAL EVALUATION}

\subsection{INTRODUCTION}

The purpose of this evaluation is to show that the DOT 7A, Type A metal box (Capita) Industries, Inc. Part No. S 0600-0600-1080-0104) containment is not threatened by heat generated by the ion exchange columns within the package during normal conditions of transport.

\subsection{SUMHARY OF THERMAL PROPERTIES OF MATERIALS}

The columns generate less than 1 watt per metal box based on the characterization provided in Part B, Section 2.0. The heat generation per box is calculated as follows:

Box containing five columns:

${ }^{137} \mathrm{Cs}: \quad 0.0103 \mathrm{Ci} /$ box $\times 4.72 \times 10^{-3}$ watts $/ \mathrm{Ci}=4.86 \times 10^{-5}$ watts $/$ box .

${ }^{60} \mathrm{Co}: 0.0937 \mathrm{Ci} /$ box $\times 1.54 \times 10^{-2}$ watts $/ \mathrm{Cj}=$

$1.44 \times 10^{-3}$ watts/box.

${ }^{90} \mathrm{Sr}: \quad i .65 \times 10^{-3} \mathrm{Ci} /$ box $\times 6.70 \times 10^{-3}$ watts $/ \mathrm{Ci}=$

$1.1 \times 10^{-5}$ watts/box.

$4.86 \times 10^{-5}+1.44 \times 10^{-3}+1.1 \times 10^{-5}=1.5 \times 10^{-3}$ total watts/box.

Box containing three columns:

${ }^{137} \mathrm{Cs}: \quad 0.06837 \mathrm{Ci} /$ box $\times 4.72 \times 10^{-3}$ watts $/ \mathrm{Ci}=3.23 \times 10^{-4}$ watts $/$ box .

${ }^{60} \mathrm{Co}: 0.32730 \mathrm{Ci} /$ box $\times 1.54 \times 10^{-2}$ watts $/ \mathrm{Ci}=5.0 \times 10^{-3}$ watts $/$ box .

${ }^{90} \mathrm{Sr}: 0.01094 \mathrm{Ci} /$ box $\times 6.70 \times 10^{-3}$ watts $/ \mathrm{Ci}=7.32 \times 10^{-5}$ watts $/$ box.

$3.23 \times 10^{-4}+5.0 \times 10^{-3}+7.32 \times 10^{-5}=5.4 \times 10^{-3}$ total watts $/$ box .

Box containing four columns:

${ }^{137} \mathrm{Cs}: \quad 0.45689 \mathrm{Ci} /$ box $\times 4.72 \times 10^{-3}$ watts $/ \mathrm{Ci}=2.16 \times 10^{-3}$ watts $/$ box .

${ }^{60} \mathrm{Co}: 0.13322 \mathrm{Ci} /$ box $\times 1.54 \times 10^{-2}$ watts $/ \mathrm{Ci}=2.1 \times 10^{-3}$ watts $/$ box .

${ }^{90} \mathrm{Sr}: \quad 0.07310 \mathrm{Ci} /$ box $\times 6.70 \times 10^{-3}$ watts $/ \mathrm{Ci}=4.9 \times 10^{-4}$ watts $/$ box .

$2.16 \times 10^{-3}+2.1 \times 10^{-3}+4.9 \times 10^{-4}=4.75 \times 10^{-3}$ total watts $/$ box.

\subsection{SUMMARY OF THERMAL PROPERTIES OF MATERIALS}

The amount of thermal output from the radioactivity within the packaged ion exchange columns is minimal (less than 1 watt per package). Therefore, the payloads within the boxes will not cause the boxes to exceed the requirements of 49 CFR 173.442, "Thermal Limitations." The metal boxes are certified to meet $7 \mathrm{~A}$, 
Type A requirements of 49 CFR 173.412, "Additional Requirements for Type A Packages" in accordance with WHC-EP-0058, Test and Evaluation Document for DOT 7A, Type A Packages.

\subsection{THERMAL EVALUATION FOR NORMAL TRANSFER CONDITIONS}

The metal box is designed and constructed to meet applicable requirements of 49 CFR 173.412, "Additional Requirements for Type A Packages" in accordance with WHC-EP-0058, Test and Evaluation Document for DOT 7A, Type A Packaging, Section 3.0, and Table $C-3$. In addition, the metal boxes must be designed, constructed, and loaded in accordance with the requirements of 49 CFR 173.442 such that:

- The heat generated within the package because of the radioactive contents will not, at any time during transportation, affect the integrity of the package under normal conditions of transportation

- The temperature of the accessible external surfaces of the loaded package will not, assuming still air in the shade at an ambient temperature of $38^{\circ} \mathrm{C}\left(100^{\circ} \mathrm{F}\right)$, exceed either of the following:

- $50^{\circ} \mathrm{C}\left(122^{\circ} \mathrm{F}\right)$ in other than an exclusive-use shipment

- $82^{\circ} \mathrm{C}\left(180^{\circ} \mathrm{C}\right)$ in an exclusive-use shipment.

\subsection{THERMAL EVALUATION AND CONCLUSIONS}

WHC-EP-0058, Table C-3 (d) documents that the metal box would maintain containment and shielding during transportation and storage in a temperature range of $-40^{\circ} \mathrm{C}\left(-40^{\circ} \mathrm{F}\right)$ to $70^{\circ} \mathrm{C}\left(158^{\circ} \mathrm{F}\right)$ with account being taken of the possibility of brittle fracture. In addition, per Table $\mathrm{C}-3$, metals used in these boxes will not become excessively brittle at $-40^{\circ} \mathrm{C}$ and all gaskets used also meet this requirement. The metal box is not approved for liquids, so freezing of contents is not a concern. Table $\mathrm{C}-3$ goes on to indicate that temperatures of $+70^{\circ} \mathrm{C}$ will not result in any significant decrease in containment integrity.

The PRTR ion exchange columns packaged inside the metal boxes exhibit minimal characteristics of thermal decay heat generation based on the amount of radionuclides present (i.e., <1 watt per box). Because the heat generated by the radionuclides is insignificant, the temperature of the external surface of the box will approach ambient. Furthermore, the external surfaces of the box will not see temperature extremes during transportation above $70^{\circ} \mathrm{C}$ or below $-40^{\circ} \mathrm{C}$ at the Hanford Site. Therefore, no further evaluation is required. 


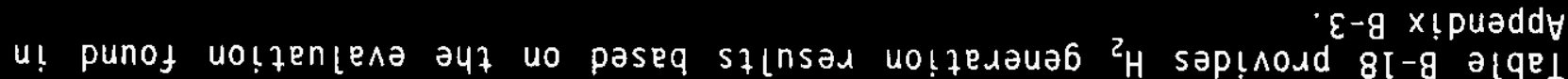

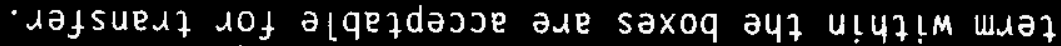

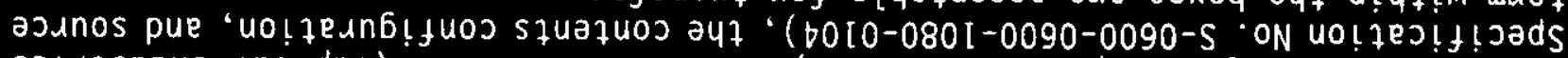

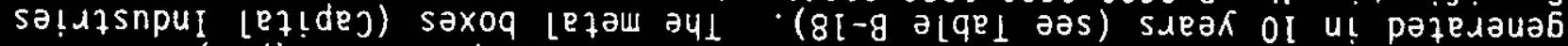

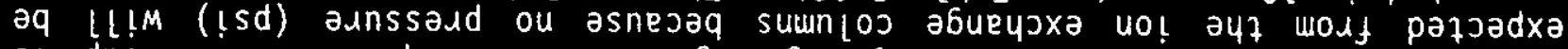
s! dnpl!nq ainssald to uo!felauab uaboupky to squnowe alqe!jaddde on

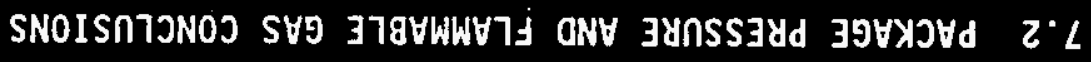

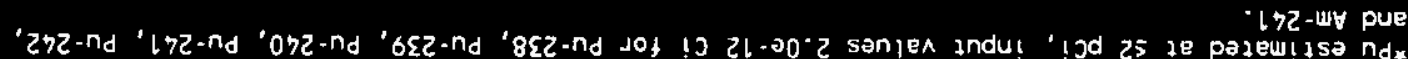

\begin{tabular}{|c|c|c|c|c|c|c|}
\hline$O \varepsilon^{\circ} 6$ & $21 \cdot 97$ & $1 \cdot 22$ & $\varepsilon-3 \Sigma^{\prime} 8$ & $7 \cdot 3 l \cdot 1$ & $2 \cdot 32 \cdot 5$ & *SL JaMO 1 \\
\hline $0 \Sigma^{\prime} 6$ & $21 \cdot 97$ & $1 \cdot 22$ & $2-39^{\circ} l$ & $5 \cdot 30^{\circ} l$ & $l-30^{\circ} \downarrow$ & S9 JaMOT \\
\hline$\angle S^{\circ} 2$ & $26^{\circ} 97$ & $06 \%$ & $7 \cdot \exists \varepsilon^{\circ} L$ & $b \cdot 30^{\circ} l$ & $\varepsilon \cdot 39^{\circ} 7$ & SS J2MOT \\
\hline $0 \varepsilon^{\circ} 6$ & 26.97 & $1 \cdot 22$ & $2 \cdot 38^{\circ} 7$ & $\tau \cdot 30^{\circ} \varepsilon$ & $1 \cdot 30^{\circ} \varepsilon$ & S7 JaMO 1 \\
\hline $05^{\circ} 6$ & $21 \cdot 97$ & $1 \cdot 22$ & $\varepsilon-3 L^{\prime} 8$ & $7-3 \varepsilon^{\circ} 6$ & $2-3 s^{\circ} s$ & SE JaMO 7 \\
\hline$\angle 5^{\prime} 2$ & 21.97 & $06^{\circ} \mathrm{L}$ & $7 \cdot 32^{\circ} \varepsilon$ & $2-36^{\circ} \mathrm{L}$ & $\varepsilon \cdot 30 \cdot 2$ & S2 JәM० 1 \\
\hline$\angle 5^{\prime} 2$ & $21 \cdot 97$ & $06^{\circ} \mathrm{L}$ & $\varepsilon-36^{\circ} !$ & $1-35^{\circ} 2$ & $2-32^{\circ} l$ & SL JaMO \\
\hline$\angle 5^{\circ} 2$ & $21 \cdot 97$ & $06^{\circ} \mathrm{L}$ & $S \cdot 3 L \cdot L$ & $\varepsilon-32 \cdot \downarrow$ & $7-3 i \cdot l$ & $\xi-X I$ \\
\hline$\angle 5^{\circ} 2$ & $21 \cdot 97$ & $06^{\circ} \mathrm{L}$ & $\varepsilon-39^{\circ} l$ & $2-38.8$ & $2 \cdot 30.1$ & $J \Sigma-X I$ \\
\hline$\angle 5^{\circ} 2$ & 21.97 & $06^{\circ} \mathrm{L}$ & $9 \cdot 38^{\circ} 9$ & $\varepsilon \cdot 39^{\circ} l$ & $5 \cdot 32^{\circ}$ & $2-x I$ \\
\hline$O \varepsilon^{\circ} 6$ & $21 \cdot 97$ & $1 \cdot 22$ & $s-30^{\circ} 2$ & $\varepsilon \cdot 36^{\circ} l$ & $7-3 E^{\circ} 1$ & $I-X I$ \\
\hline $16^{\circ} 6$ & $21 \cdot 97$ & 6.52 & $9 \cdot 3 L^{\circ} 2$ & $7-38.5$ & $5 \cdot 3 L 1$ & $5 \cdot \times 18$ \\
\hline 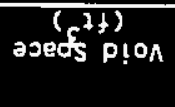 & 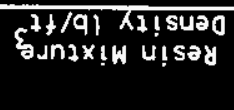 & 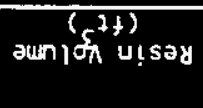 & $\mathrm{t}_{06} / \mathrm{JS} 06$ & $\begin{array}{c}{ }_{009} \\
1+1 ! 1 !\end{array}$ & $5 J_{L \Sigma l}$ & 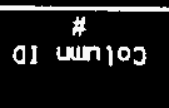 \\
\hline
\end{tabular}

- 7äyspeauds u! pasn sanlen fnduI $\angle[-g$ alqel

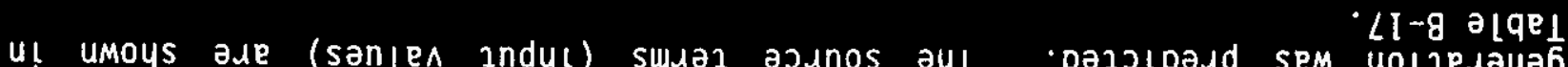

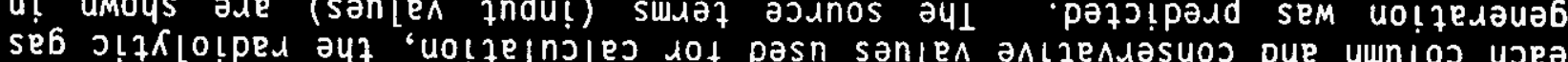

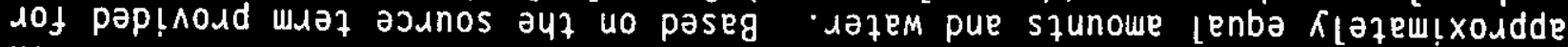
u! u!sad uo!zes pue uo!̣e pax!̣ u!equos sumnlos abueysxa vo! ay

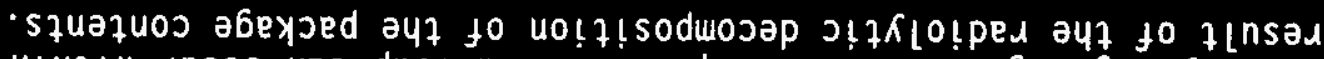

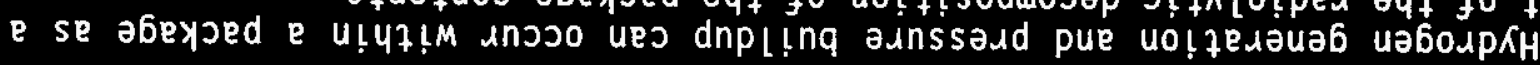

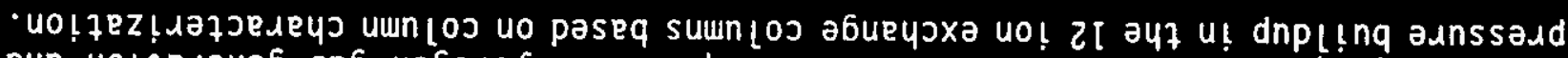
pue uo!fedaueb se6 uaboupky fo!pand of s! uo!fenlena s!yf to asodind ay! 
WHC-SD-TP-SEP-035 Rev. 1

Table B-18. $\mathrm{H}_{2}$ Generation Results.

\begin{tabular}{|l|c|c|c|c|}
\hline Column ID & Years Sealed & $\begin{array}{c}\text { Gas Generation } \\
\text { Rate at 10 } \\
\text { Years Icc/hr\} }\end{array}$ & $\begin{array}{c}\text { Hydrogen } \\
\text { Concentration at } \\
10 \text { Years }\end{array}$ & $\begin{array}{c}\text { Pressure at } \\
10 \text { Years } \\
\text { (psi) }\end{array}$ \\
\hline BIX-5 & 10 & $9.9 \mathrm{E}-06$ & $0.00031 \%$ & 0.0 \\
\hline IX-1 & 10 & $3.3 \mathrm{E}-5$ & $0.0011 \%$ & 0.0 \\
\hline IX-2 & 10 & $2.7 \mathrm{E}-5$ & $0.0033 \%$ & 0.0 \\
\hline IX-3F & 10 & $1.6 \mathrm{E} \cdot 3$ & $0.19 \%$ & 0.0 \\
\hline IX-3 & 10 & $2.2 \mathrm{E}-5$ & $0.0026 \%$ & 0.0 \\
\hline Lower 1S & 10 & $4.3 \mathrm{E}-3$ & $0.52 \%$ & 0.0 \\
\hline Lower 2S & 10 & $1.3 \mathrm{E}-3$ & $0.16 \%$ & 0.0 \\
\hline Lower 3S & 10 & $8.5 \mathrm{e}-4$ & $0.028 \%$ & 0.0 \\
\hline Lower 4S & 10 & $5.1 \mathrm{e}-3$ & $0.17 \%$ & 0.0 \\
\hline Lower 5S & 10 & $1.7 \mathrm{e}-3$ & $0.21 \%$ & 0.0 \\
\hline Lower 6S & 10 & $1.5 \mathrm{e}-3$ & $0.051 \%$ & 0.0 \\
\hline Lower 7S & 10 & $7.9 \mathrm{e}-4$ & $0.026 \%$ & 0.0 \\
\hline
\end{tabular}


WHC-SD-TP-SEP-035 Rev. 1

APPENDIX B-3

ENGINEERING SAFETY EVALUATION:

ION EXCHANGE COLUMN $\mathrm{H}_{2}$ GENERATION ENGINEERING SAFETY EVALUATION

$B C-1$

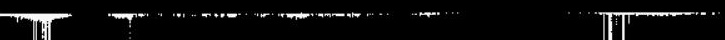


ENGINEERING SAFETY EVALUATION Subject $\frac{\text { Ion Exchange column } H_{2} \text { Generat ion Evaluation }}{\text { Originator }-1, R_{2} \text { Grean }}$ Checker

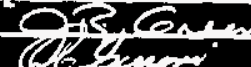

Page 1 of 2

Date Date $\frac{1212 \sqrt{25}}{\ln 2}$

\section{Obiactives:}

Determination of hydrogen gas generation and pressure buildup in twelve ion exchange columns.

\section{References:}

1. GEND-041, "A Calculation Technique to Predict Combustible Gas Generation in Sealed Radioactive Waste Containers," dated May 1986.

2. MHC 1994, "Progress Report for the Enhancement of Radcalc: Isotope Database, Gamma Absorption Fractions, and $G\left(H_{2}\right)$ Values, "WHC-SO-TP-RPT-014.

\section{Results and conclusions:}

The results are given in Tabie 1.

Table 1. $\mathrm{H}_{2}$ generation results.

\begin{tabular}{|c|c|c|c|c|}
\hline Column 10 & Youre sentod & $\begin{array}{l}\text { Ges Conaration } \\
\text { Pate it } 10 \\
\text { Youss feemal }\end{array}$ & $\begin{array}{l}\text { Hydronan } \\
\text { Coneontration at } \\
10 \text { Yours }\end{array}$ & $\begin{array}{l}\text { Preature at } \\
10 \text { Yoere } \\
\text { (pall }\end{array}$ \\
\hline$B I X-5$ & 10 & $0.0 E-03$ & $0.00031 \%$ & 0.0 \\
\hline IX-1 & 10 & $3.3 E-5$ & $0.0011 \%$ & 0.0 \\
\hline $1 x-2$ & 10 & $2.7 E-5$ & $0.0033 x$ & 0.0 \\
\hline DX-sF & 10 & $1.8 E-3$ & $0.10 x$ & 0.0 \\
\hline$x-3$ & 10 & $2.25-6$ & $0.0028 x$ & 0.0 \\
\hline Lower 15 & 10 & $4.35-3$ & $0.52 x$ & 0.0 \\
\hline Lower 25 & 10 & $1.35-3$ & $0.18 \%$ & 0.0 \\
\hline Lower 35 & 10 & 6.5e-4 & $0.023 x$ & 0.0 \\
\hline Lowar 45 & 10 & $5.10-3$ & $0.17 \%$ & 0.0 \\
\hline Lower 58 & 10 & $1.7 a-3$ & $0.21 \%$ & 0.0 \\
\hline Lowar es & 10 & $1.50-3$ & $0.051 \%$ & 0.0 \\
\hline Lowar 78 & 10 & $7.00-4$ & $0.028 \%$ & 0.0 \\
\hline
\end{tabular}


ENGINEERING SAFETY EVALUATION

Subject Ion Exchange Column $\mathrm{H}_{2}$ Generation Evaluation

Originator J.R.Green

Checker

R. P. Genon

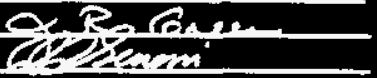

Date $\frac{\text { Page } 2 \text { of } 2}{1 / 2 / 2 / 25}$

\section{Engineering Evaluation:}

The calculation technique described in Reference 1 was used to predict the radiolytic gas generation in twelve ion exchange columns. The spreadsheet provided with Reference 1 was the analytical tool used in this calculation. The methodology has been approved by the U.S. Nuclear Regulatory Commission (NRC) as a means for determining hydrogen gas generation rates.

The source term used in the spreadsheets is listed in Table 2 along with additional input values. The fon exchange columns contain mixed anion and cation res in in approximately equal amounts, and water. The $G\left(H_{2}\right)$ value used in the spread sheet was 0.5. The number is a conservative value based on $G\left(\mathrm{H}_{2}\right)$ information contained in Reference 2.

See spreadsheet and data library attached.

Table 2. Input values used in spreadsheet.

\begin{tabular}{|c|c|c|c|c|c|c|}
\hline \multirow[b]{2}{*}{ colun in } & \multicolumn{3}{|c|}{ Aetivity (Ci) } & \multirow[b]{2}{*}{$\begin{array}{c}\text { Realin yolume } \\
\left(f t^{-}\right)\end{array}$} & \multirow[b]{2}{*}{$\begin{array}{l}\text { Resin Mixtures } \\
\text { Density }\left(b / f t^{3}\right.\end{array}$} & \multirow[b]{2}{*}{$\begin{array}{l}\text { Void spoece } \\
\left(\mathrm{ft}^{\mathrm{s}}\right)\end{array}$} \\
\hline & $137 \mathrm{cs}$ & $0_{\mathrm{co}}$ & $90_{S r /} 90_{Y}$ & & & \\
\hline FIX-5 & $1.75=5$ & $5, x \in-6$ & $2.7=6$ & 25.9 & 46.12 & 9.97 \\
\hline $2 x-1$ & $1.3 E-4$ & $1.95-3$ & $2.05-5$ & 22.1 & 46.12 & 9.30 \\
\hline$I x-2$ & $4-2 E-5$ & 1.6E-3 & $6.85-6$ & 7.90 & 46.12 & 2.57 \\
\hline$[x-3] f$ & $1,0=2$ & B.PE-? & 1.6E-3 & $7 . \%$ & 46.12 & 2,57 \\
\hline $1 x-3$ & $1.1 E-4$ & $1.2 E-3$ & $1 . \pi-5$ & 7.90 & 46.12 & 2.57 \\
\hline Lower is. & $1.25-2$ & $2.55-1$ & $1.9=-3$ & 7.90 & 46.12 & 2.57 \\
\hline Lower 25 & $2.05-3$ & $7.9 E-2$ & $3.2 E-4$ & 7.00 & 46.12 & 2.57 \\
\hline Lower 35 & $5.5 E \cdot 2$ & $9.3 E-4$ & $8 \cdot \pi-3$ & 22.1 & 46.12 & 9.30 \\
\hline Loure is & $3,0=-1$ & $3,0=2=?$ & $6,85 \cdot 2$ & 23,1 & 46.17 & 9.30 \\
\hline Lower 58 & $4.6 E-3$ & $1.0 E-1$ & $7.3 E-4$ & 7.90 & 46.12 & 2.57 \\
\hline Lower 65 & 1.0E-1 & $1.0 E-3$ & $1.65=2$ & 22.1 & 46.12 & 9.30 \\
\hline Lower $7 \mathrm{~s}^{*}$ & $5.26-2$ & 1.1E-4 & $0.3 E-3$ & 22.1 & 46.12 & 9.30 \\
\hline
\end{tabular}

कPu estingted at $\leq 2$ pci, Input valuse 2.0e-12 ci for Pu-238, Pu-239, Pu-240, Pu-241, Pu-242, and $\mathrm{in}-241$. 


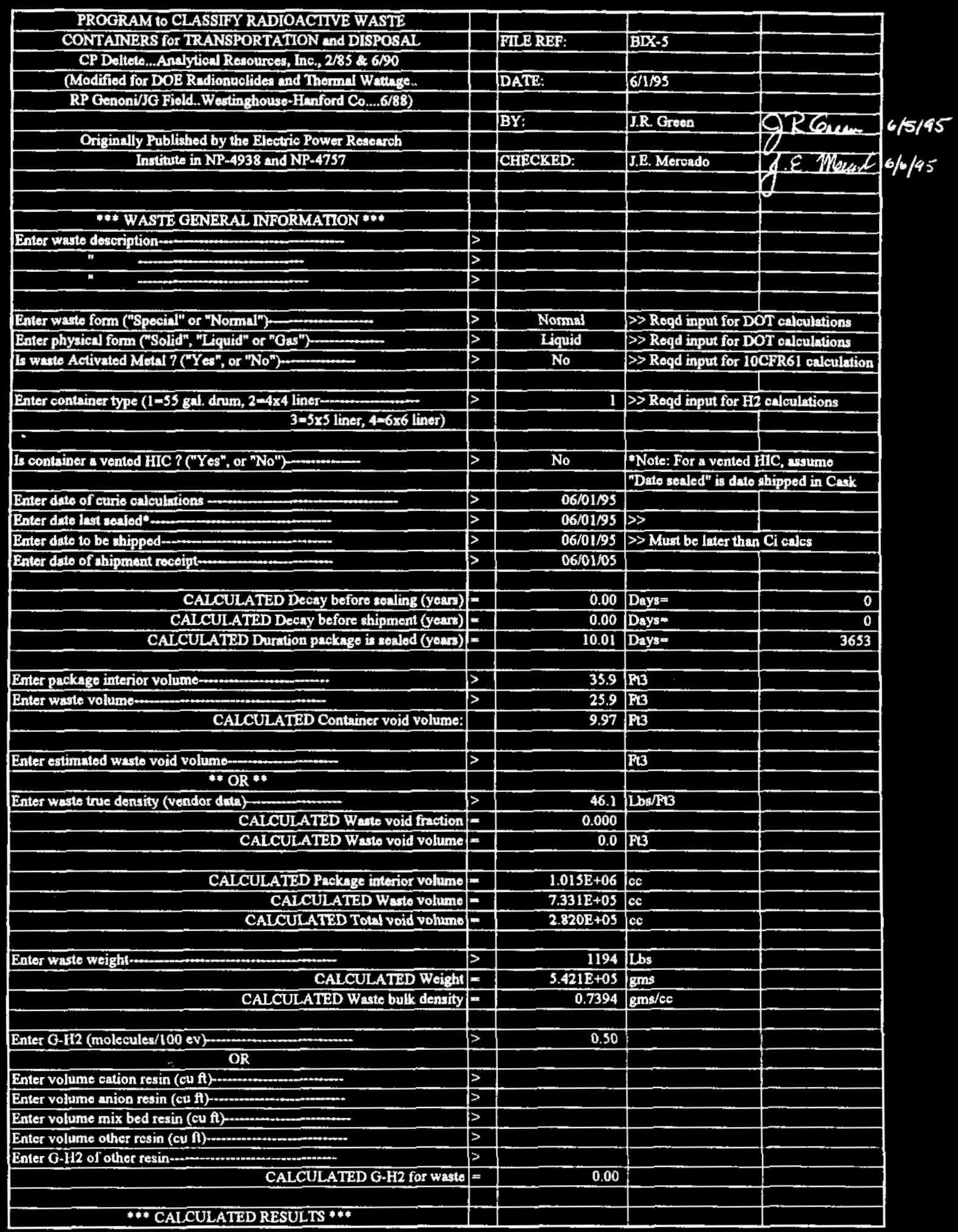




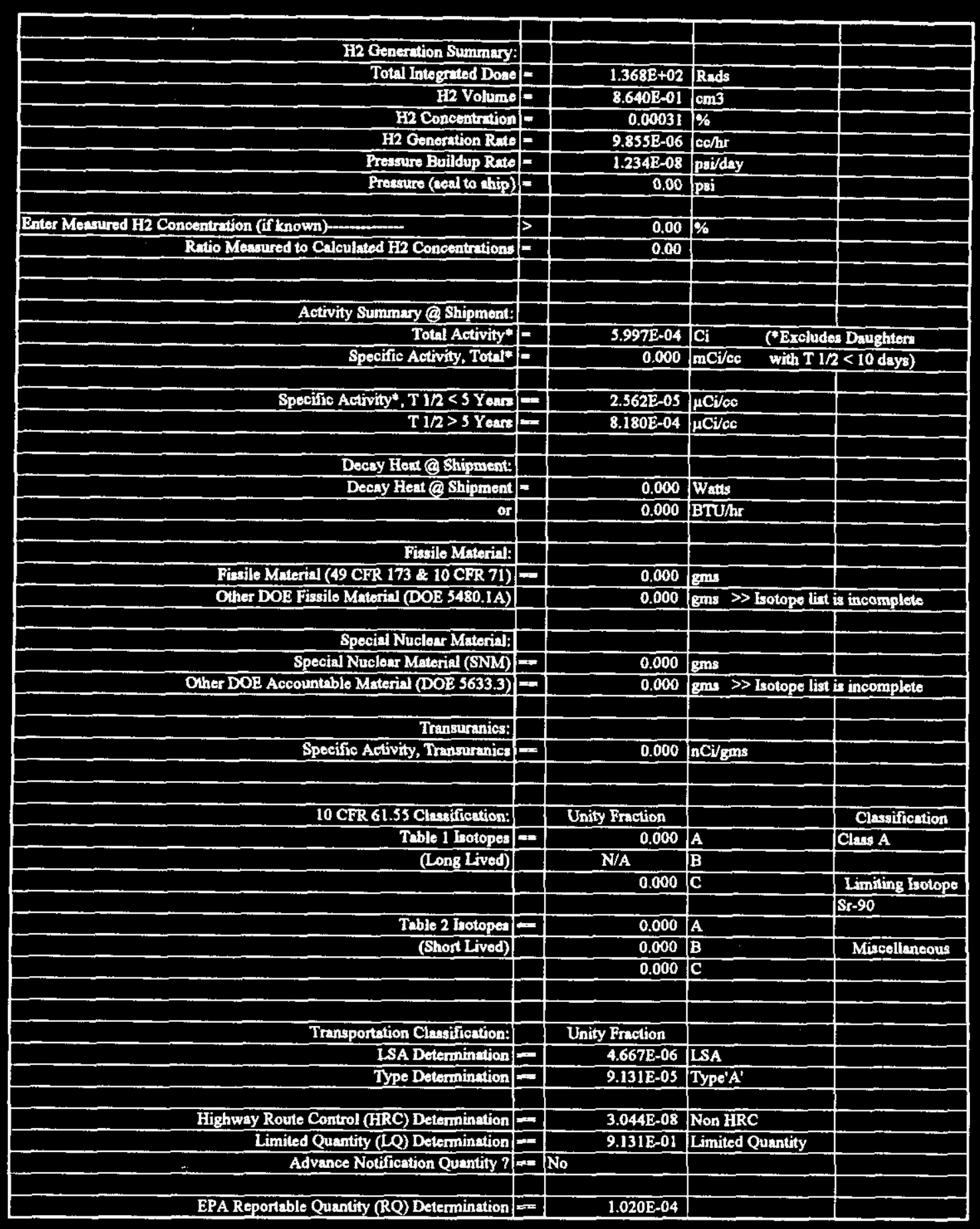




\begin{tabular}{|c|c|c|c|c|c|c|}
\hline & \multicolumn{6}{|c|}{ INPUT: LISTED ISOTOPES } \\
\hline & & N" - Daughter Produ & & & Curies when & Curies when \\
\hline & & Curies & or & $\%$ & Sollod & Shipped \\
\hline & Total Curies & & & $\cdot$ & & \\
\hline & (0) & NLY if entering $\%)$ & & & $\operatorname{mxx}$ & $\operatorname{xxx\times x}$ \\
\hline & $\mathrm{H}-3 \mathrm{-3} \rightarrow$ & & & & $0.000 \mathrm{E}+00$ & $0.000 \mathrm{E}+00$ \\
\hline & $0.14 \ldots$ & & & & $0.600 \mathrm{E}+00$ & $0.000 \mathrm{E}+00$ \\
\hline & $\mathrm{Na}-22 \longrightarrow$ & & & & $0.000 \mathrm{E}+00$ & $0.000 \mathrm{E}+00$ \\
\hline & Cr-51 $\rightarrow$ & & & & $0.000 \mathrm{E}+00$ & $0.000 \mathrm{E}+00$ \\
\hline & Mn.54-1 & & & & $0.000 \mathrm{E}+00$ & $0.000 \mathrm{E}+00$ \\
\hline & Fo-S5 $-\infty$ & & & & $0.000 \mathrm{~B}+00$ & $0.000 \mathrm{E}+00$ \\
\hline & 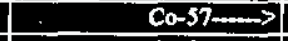 & & & & $0.000 \mathrm{~B}+00$ & $0.000 \mathrm{E}+00$ \\
\hline & Co-58m $\rightarrow$ & & & & $0.000 \mathrm{~B}+00$ & $0.000 \mathrm{E}+00$ \\
\hline & Po.59-...> & & & & $0.000 \mathrm{~B}+60$ & $0.000 \mathrm{E}+00$ \\
\hline & $\mathrm{Ni} i 59 \ldots$ & & & & $0.000 \mathrm{E}+00$ & $0.000 \mathrm{E}+00$ \\
\hline & $\mathrm{Co}-60-\longrightarrow$ & $5.800 \mathrm{E} \cdot 04$ & & & $5.800 \mathrm{E}-04$ & $5.800 \mathrm{E}-04$ \\
\hline & $\mathrm{Ni} i-63-\mathrm{m}$ & & & & $0.000 \mathrm{E}+00$ & $0.000 \mathrm{E}+00$ \\
\hline & $2 n-65 \ldots$ & & & & $0.000 \mathrm{E}+00$ & $0.000 \mathrm{E}+00$ \\
\hline & So-79...> & & & & $0.000 \mathrm{E}+00$ & $0.000 \mathrm{E}+00$ \\
\hline & Kr-85 > > & & & & $0.000 \mathrm{E}+00$ & $0.000 \mathrm{E}+00$ \\
\hline & sr-89-..> & & & & $0.000 \mathrm{E}+00$ & $0.000 \mathrm{E}+00$ \\
\hline & $5 r-90-\longrightarrow$ & $2.700 \mathrm{E}-06$ & & & $2.700 \mathrm{E}-06$ & $2.700 \mathrm{E}-06$ \\
\hline & $\mathrm{Y}-90 \rightarrow \ldots$ & tom: & & + & $2.700 \mathrm{E}-06$ & $2.700 \mathrm{E}-06$ \\
\hline & $Y \cdot 91 \rightarrow$ & & & & $0.0002+00$ & $0.000 \mathrm{~B}+00$ \\
\hline & $2 x-93-1,>$ & & & & $0.000 \mathrm{E}+00$ & $0.000 \mathrm{E}+00$ \\
\hline & Nb.93m-n & & & & $0.000 \mathrm{E}+00$ & $0.000 \mathrm{E}+00$ \\
\hline & $\mathrm{Nb} b 94-\infty$ & & & & $0.000 \mathrm{E}+00$ & $0.000 \mathrm{E}+00$ \\
\hline & $2 r-95 \ldots$ & & & & $0.000 \mathrm{E}+00$ & $0.000 \mathrm{E}+00$ \\
\hline & Nb-95_- > & & & & $0.000 \mathrm{E}+00$ & $0.000 \mathrm{E}+00$ \\
\hline & $\mathrm{Nb}-95 \mathrm{~m}-m-\infty$ & & & & $0.0005+00$ & $0.000 \mathrm{E}+00$ \\
\hline & TE-99 & & & & $0.000 \mathrm{E}+00$ & $0.000 \mathrm{E}+00$ \\
\hline & Ru-103-m & & & & $0.000 \mathrm{E}+00$ & $0.000 \mathrm{E}+00$ \\
\hline & Bh-103mm- & $+\infty$ & & $\operatorname{tin}$ & $0.000 \mathrm{E}+00$ & $0.000 \mathrm{E}+00$ \\
\hline & Ru-106-..> & & & & $0.000 \mathrm{E}+00$ & $0.000 \mathrm{E}+00$ \\
\hline & Rh-106- $\rightarrow$ & 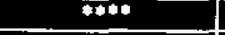 & & 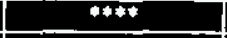 & $0.000 \mathrm{E}+00$ & $0.000 \mathrm{E}+00$ \\
\hline & Pd-107-ar.: & & & & $0.000 \mathrm{E}+00$ & $0.000 \mathrm{E}+00$ \\
\hline & $\mathrm{Cd}-109 \rightarrow->$ & & & & $0.000 \mathrm{E}+00$ & $0.000 \mathrm{E}+00$ \\
\hline & $A g-110 \mathrm{~m} \rightarrow \longrightarrow$ & & & & $0.000 \mathrm{E}+00$ & $0.000 \mathrm{E}+00$ \\
\hline & Ag, $110 \cdots$ & $+\infty$ & & $+\infty$ & $0.000 \mathrm{E}+00$ & $0.000 \mathrm{E}+00$ \\
\hline & Sn-113 $\ldots$ & & & & $0.000 \mathrm{E}+00$ & $0.000 \mathrm{E}+00$ \\
\hline & In-113m----> & $+\infty+1$ & & 4 & $0.000 E+00$ & $0.000 \mathrm{E}+00$ \\
\hline & $C d-113 \mathrm{~m}->$ & & & & $0.000 \mathrm{E}+00$ & $0.000 \mathrm{E}+00$ \\
\hline & Cd-115m $\rightarrow$ & & & & $0.000 \mathrm{E}+00$ & $0.000 \mathrm{E}+00$ \\
\hline & $5 n-119 m-\infty$ & & & & $0.000 \mathrm{E}+00$ & $0.000 \mathrm{E}+00$ \\
\hline & Sn-121mm- & & & & $0.000 \mathrm{E}+00$ & $0.000 \mathrm{E}+00$ \\
\hline & Sn-123 $\longrightarrow$ & & & & $0.000 \mathrm{E}+00$ & $0.000 \mathrm{E}+00$ \\
\hline & Te-123m $\rightarrow$ & & & & $0.000 \mathrm{E}+00$ & $0.000 \mathrm{E}+00$ \\
\hline & Sb-124 $\ldots$ & & & & $0.000 \mathrm{E}+00$ & $0.000 \mathrm{E}+00$ \\
\hline & $\mathrm{sb-125 \ldots \ldots}$ & & & & $0.000 \mathrm{E}+00$ & $0.000 \mathrm{E}+00$ \\
\hline & Te-125mal & & & & $0.000 \mathrm{E}+00$ & $0.000 \mathrm{E}+00$ \\
\hline & $\mathrm{Sn}-126-\ldots$ & & & & $0.000 \mathrm{E}+00$ & $0.000 \mathrm{E}+00$ \\
\hline & $S b-126 m \cdot . . \rightarrow$ & $+\infty$ & & 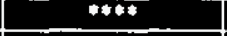 & $0.000 \mathrm{E}+00$ & $0.000 \mathrm{E}+00$ \\
\hline & $\mathrm{sb}-126 \ldots$ & & & & $0.000 \mathrm{E}+00$ & $0.000 \mathrm{E}+\infty 0$ \\
\hline & Te-127m- $\rightarrow$ & & & & $0.000 \mathrm{E}+00$ & $0.000 \mathrm{E}+00$ \\
\hline & To-127 $\ldots$ & $+\infty$ & & $*+\infty *$ & $0.000 \mathrm{E}+00$ & $0.000 \mathrm{E}+00$ \\
\hline & Te-129m $\cdots$ & & & & $0.000 \mathrm{E}+00$ & $0.000 \mathrm{E}+00$ \\
\hline & Te-129 & +20 & & $\cdots * *$ & $0.000 \mathrm{E}+00$ & $0.000 \mathrm{E}+00$ \\
\hline & 1.129....> & & & & $0.000 \mathrm{E}+00$ & $0.000 \mathrm{E}+00$ \\
\hline & $1-131 \ldots$ & & & & $0.000 \mathrm{E}+00$ & $0.000 \mathrm{E}+00$ \\
\hline & Cs-134-nos & & & & $0.000 \mathrm{E}+00$ & $0.000 \mathrm{E}+00$ \\
\hline & Cs-135 $\ldots$ & & & & $0.000 \mathrm{E}+00$ & $0.000 \mathrm{E}+00$ \\
\hline
\end{tabular}




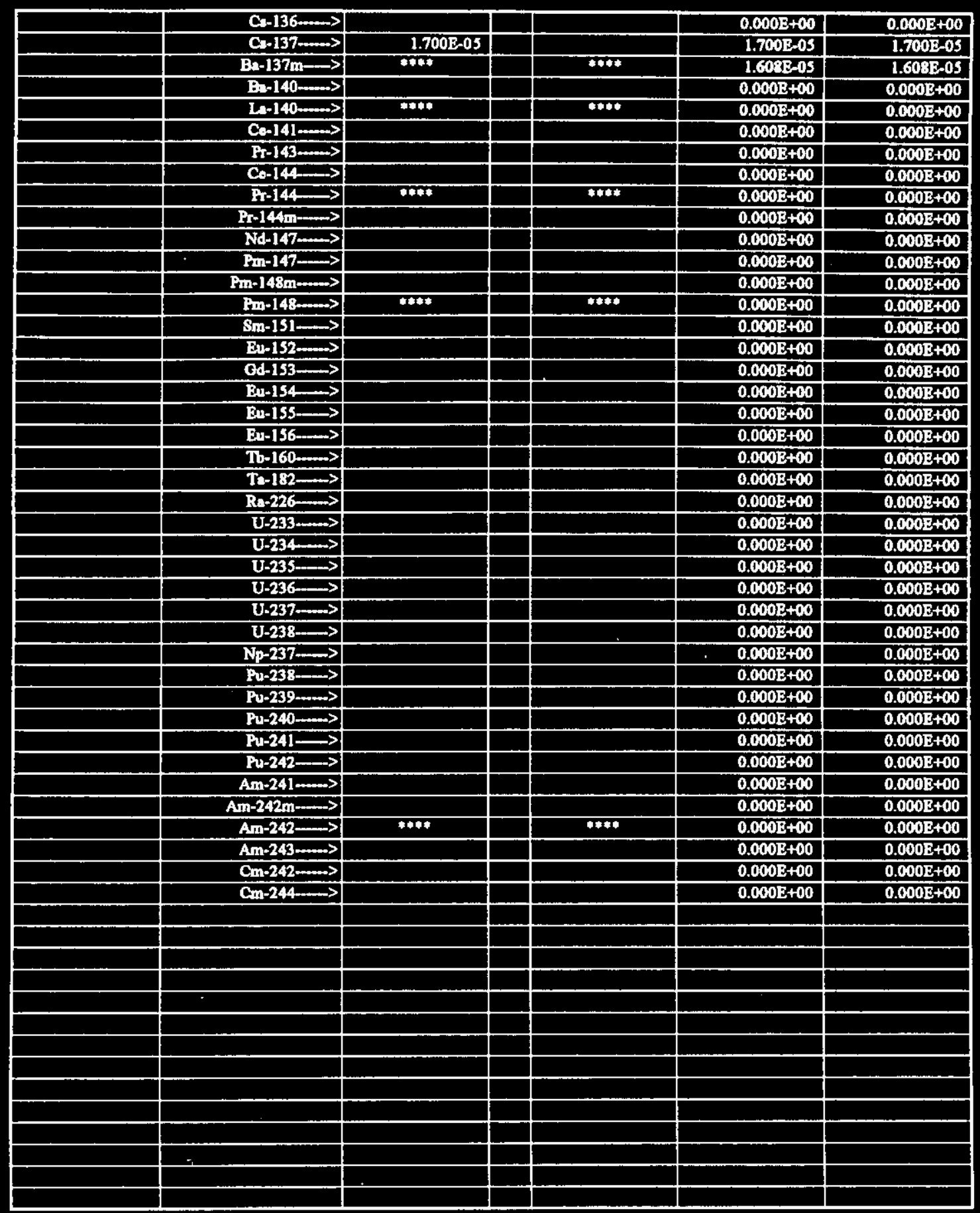




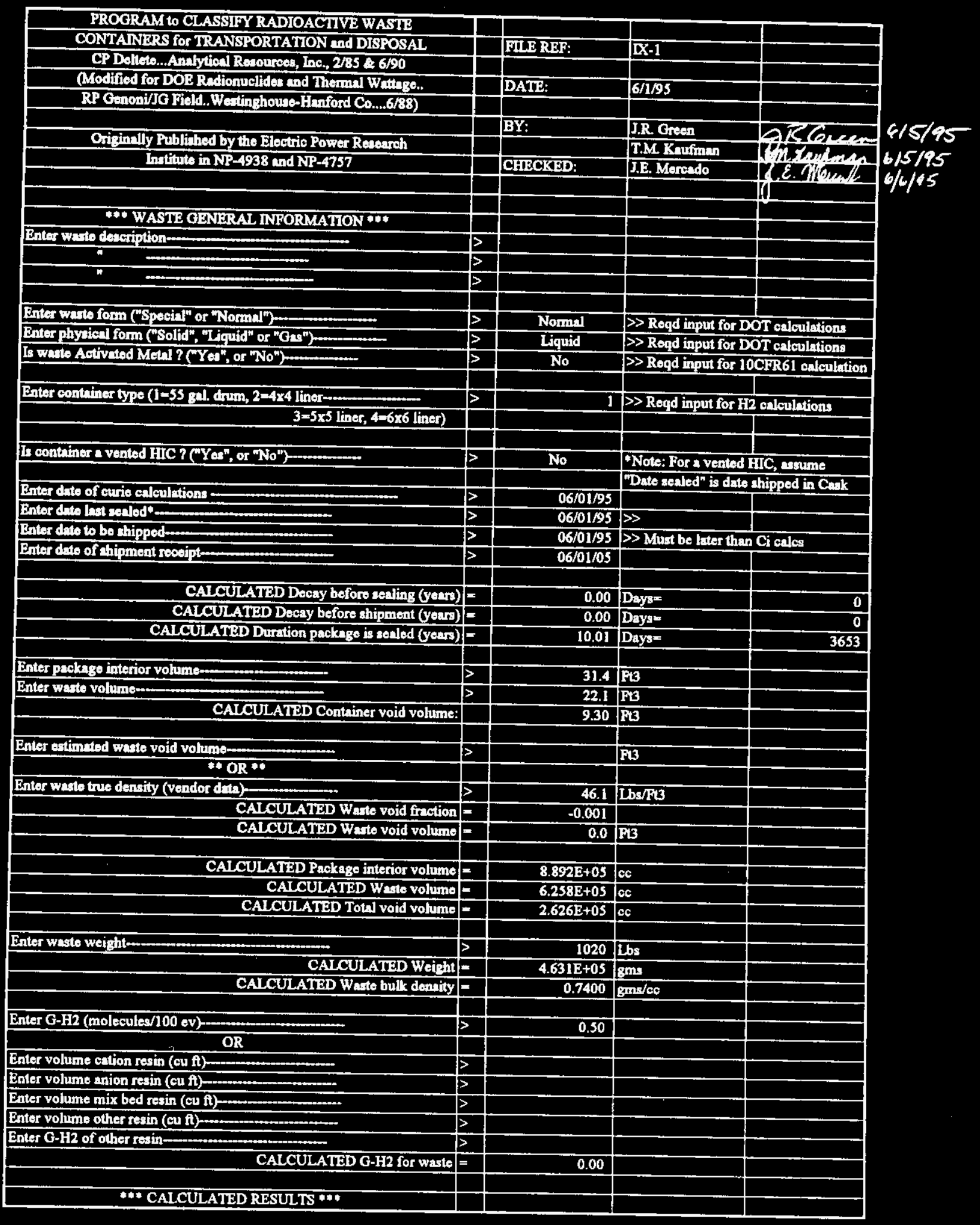




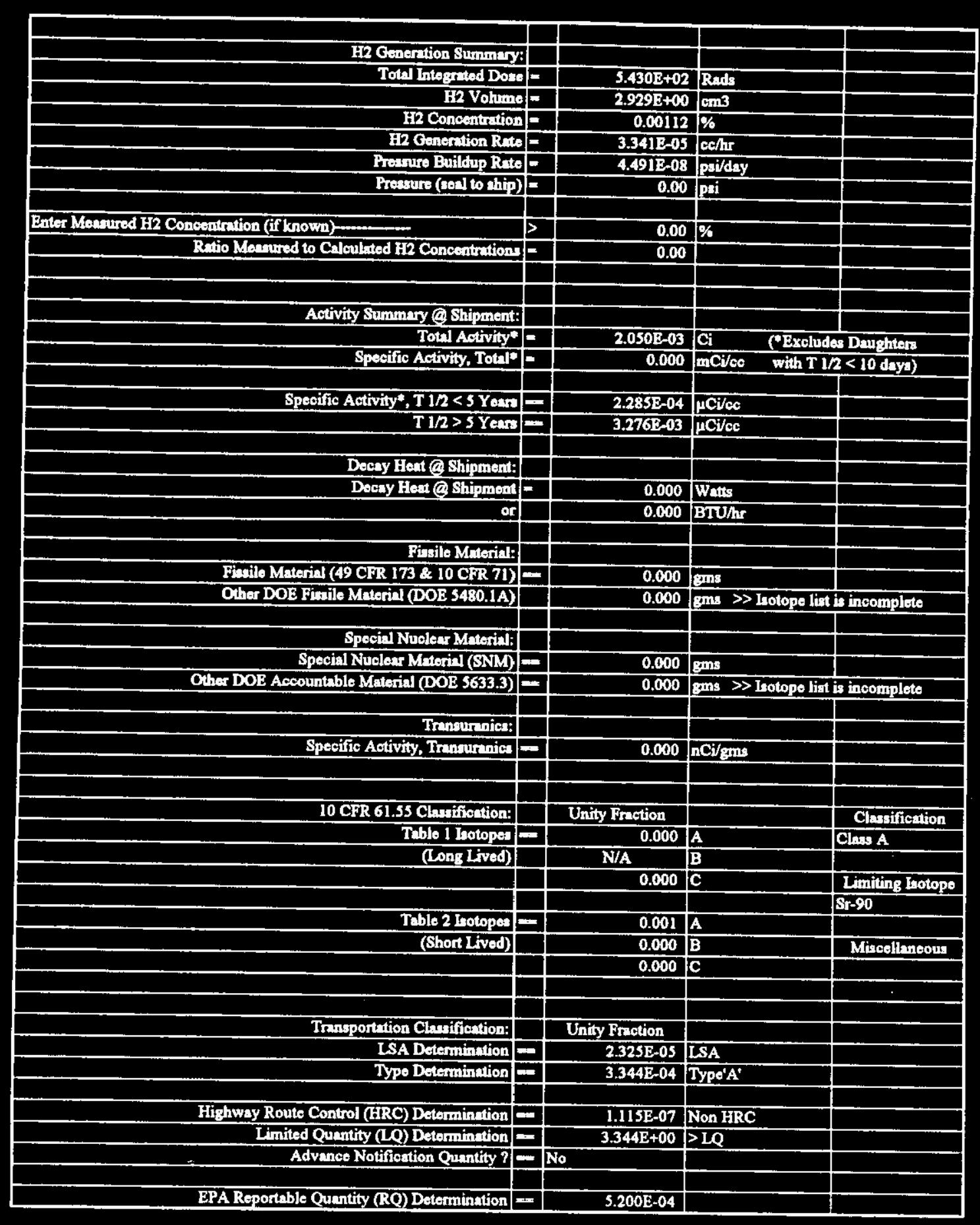




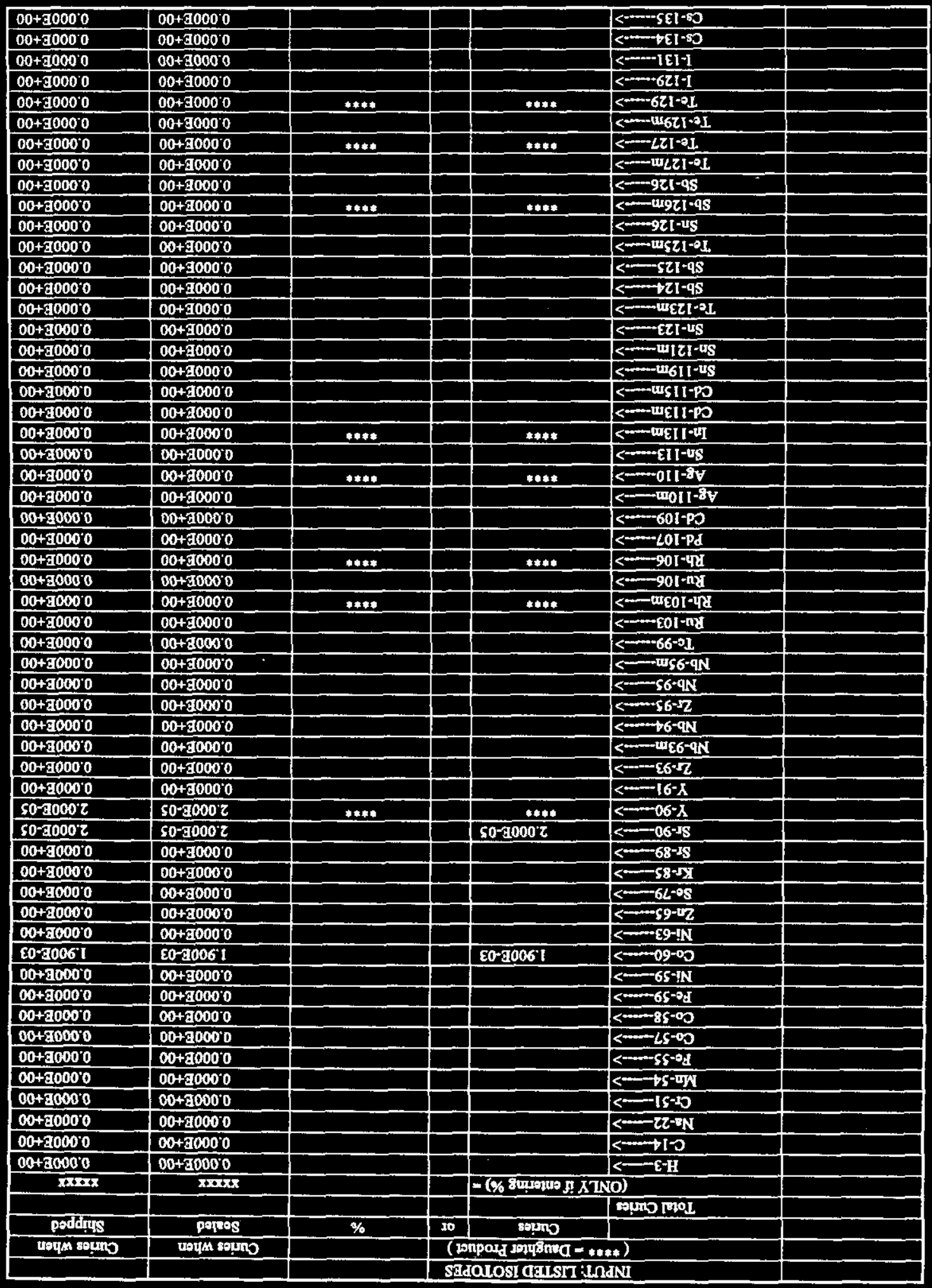




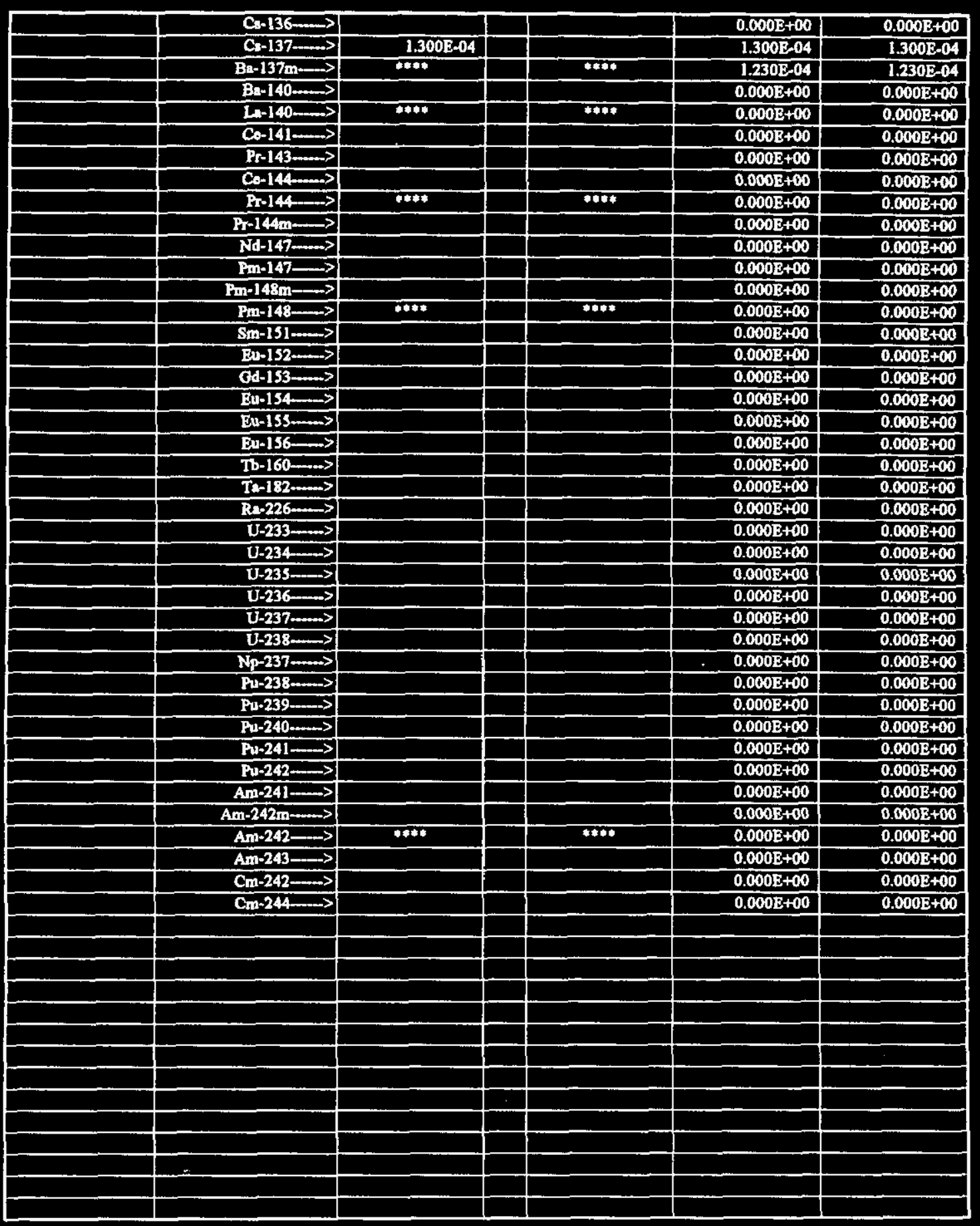




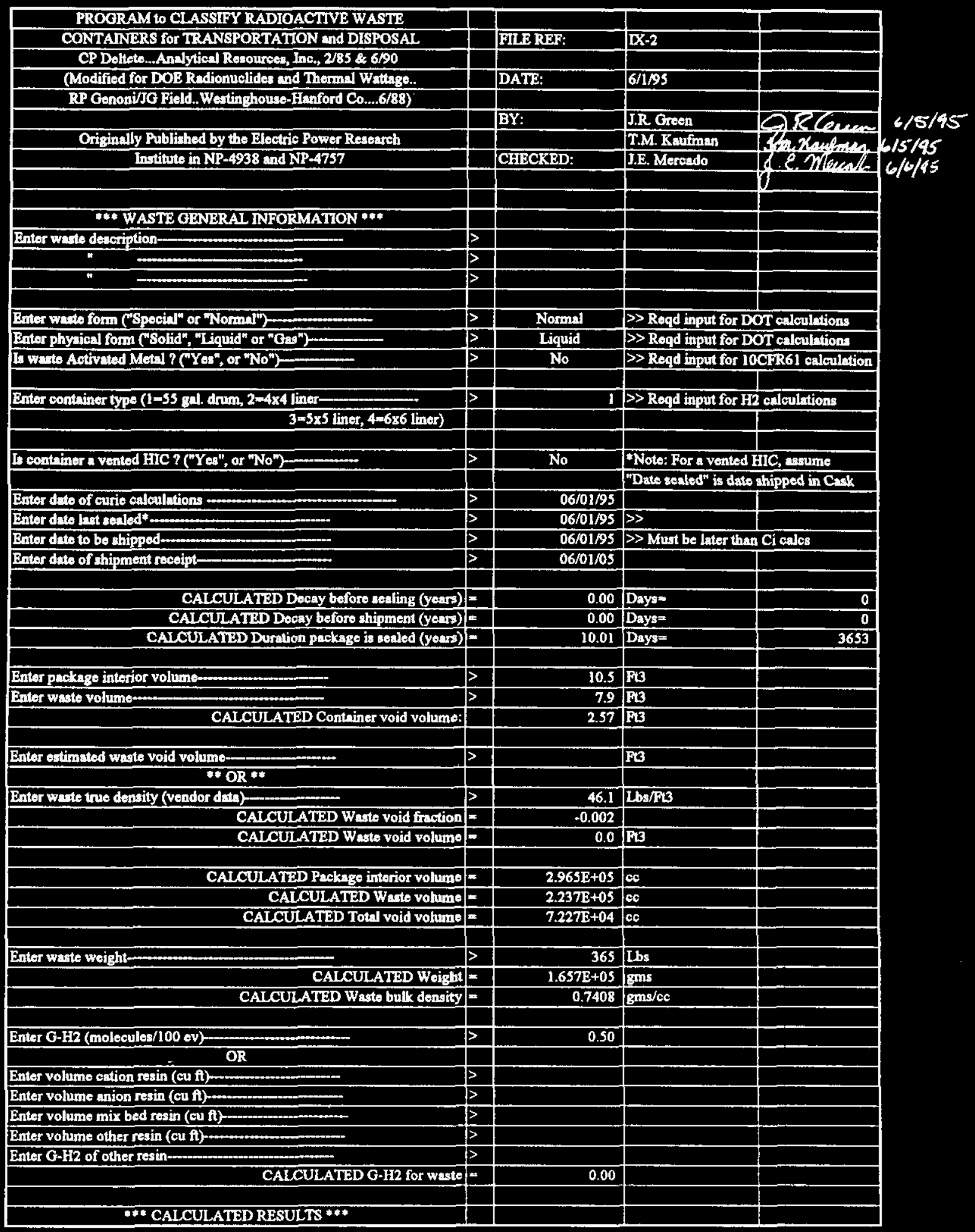




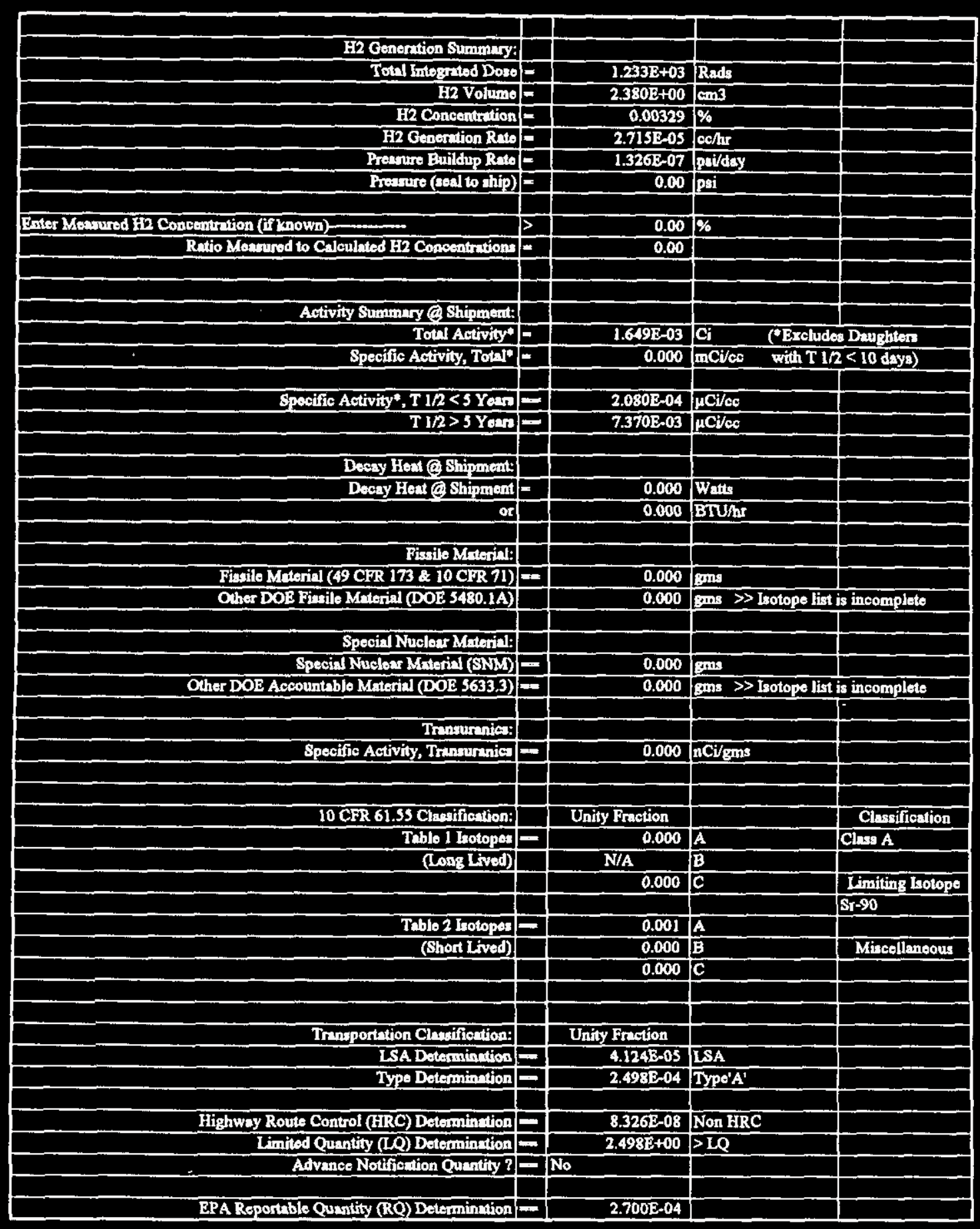


WHC-SD-TP-SEP-035 Rev. I

\begin{tabular}{|c|c|c|c|c|c|c|}
\hline & \multirow{2}{*}{\multicolumn{3}{|c|}{$\begin{array}{l}\text { INPUT: LISTRD ISOTOPES } \\
\text { (****=Daughter Product) }\end{array}$}} & \multirow[b]{3}{*}{$\%$} & \multirow{3}{*}{$\begin{array}{c}\text { Curies when } \\
\text { Sealod }\end{array}$} & \multirow{3}{*}{$\begin{array}{c}\text { Curies when } \\
\text { Shipped }\end{array}$} \\
\hline & & - Daughter Produc & & & & \\
\hline & & Curies & or & & & \\
\hline & Total Curies & & & & & \\
\hline & \multicolumn{2}{|c|}{ (ONLY if entering \%) $=$} & & & $\operatorname{xxxxx}$ & $\operatorname{sxx}$ \\
\hline & $\mathrm{H}-3-\mathrm{C}$ & & & & $0.000 \mathrm{E}+00$ & $0.000 \mathrm{E}+00$ \\
\hline & C.14 & & & & $0.000 \mathrm{E}+00$ & $0.000 \mathrm{E}+00$ \\
\hline & $\mathrm{Na}-22 \cdots$ & & & & $0.000 \mathrm{E}+00$ & $0.000 \mathrm{~B}+00$ \\
\hline & Crs $51-\infty$ & & & & $0.0003+00$ & $0.000 \mathrm{E}+00$ \\
\hline & $\mathrm{Mn}-54 \rightarrow$ & & & & $0.000 \mathrm{E}+00$ & $0.000 \mathrm{E}+00$ \\
\hline & ForS5. $\rightarrow$ & & & & $0.000 \mathrm{E}+00$ & $0.000 \mathrm{E}+00$ \\
\hline & Co-57 $\longrightarrow$ & & & & $0.000 \mathrm{E}+00$ & $0.000 \mathrm{E}+00$ \\
\hline & Co.58- $\rightarrow$ & & & & $0.000 \mathrm{E}+00$ & $0.000 \mathrm{E}+00$ \\
\hline & Fo-59- $->$ & & & & $0.000 \mathrm{E}+00$ & $0.0003+\infty 0$ \\
\hline & $N \cdot 59-1$ & & & & $0.000 \mathrm{E}+00$ & $0.000 \mathrm{E}+00$ \\
\hline & Co-60-1- & $1.600 \mathrm{E}-03$ & & & $1.600 \mathrm{E} \cdot 03$ & $1.600 \mathrm{E}-03$ \\
\hline & $\mathrm{Ni}-63-\longrightarrow$ & & & & $0.000 \mathrm{E}+60$ & $0.000 \mathrm{E}+00$ \\
\hline & $2 n-65 m$ & & & & $0.000 \mathrm{E}+00$ & $0.000 \mathrm{E}+00$ \\
\hline & So-79--.>> & & & & $0.000 \mathrm{E}+\infty 0$ & $0.000 \mathrm{E}+00$ \\
\hline & 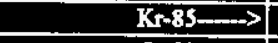 & & & & $0.000 \mathrm{E}+00$ & $0.000 \mathrm{~B}+00$ \\
\hline & $8 r-89 \ldots$ & & & & $0.000 \mathrm{E}+00$ & $0.000 \overline{\mathrm{E}+00}$ \\
\hline & $8 \mathrm{~s}-90 \mathrm{n}-\mathrm{C}$ & $6.800 \mathrm{E}-06$ & & & $6.800 \mathrm{E}-06$ & $6.800 \mathrm{E}-06$ \\
\hline & Y.90- $->$ & $\cos$ & & $x \rightarrow \infty$ & $6.800 \mathrm{E}-06$ & $6.800 \mathrm{E}-06$ \\
\hline & Y.91- & & & & $0.000 \mathrm{E}+00$ & $0.000 \mathrm{E}+\infty 0$ \\
\hline & Zr.93- $\rightarrow$ & & & & $0.000 \mathrm{E}+00$ & $0.000 \mathrm{E}+00$ \\
\hline & $\mathrm{Nb}-93 \mathrm{~m}=\mathrm{m}$ & & & & $0.000 \mathrm{E}+00$ & $0.000 \mathrm{E}+00$ \\
\hline & No-94- & & & & $0.000 \mathrm{E}+00$ & $0.000 \mathrm{E}+00$ \\
\hline & $2 r-95+\infty$ & & & & $0.000 \mathrm{E}+00$ & $0.000 \mathrm{~B}+00$ \\
\hline & $\mathrm{Nb}-95-\mathrm{m}-\mathrm{m}$ & & & & $0.000 \mathrm{E}+00$ & $0.000 \mathrm{E}+\infty 0$ \\
\hline & Nb-9S/n- & & & & $0.000 \mathrm{E}+00$ & $0.000 \mathrm{E}+00$ \\
\hline & $T C-99-\infty n_{0}>$ & & & & $0.000 \mathrm{E}+00$ & $0.000 \mathrm{E}+00$ \\
\hline & Ru-103 & & & & $0.000 \mathrm{E}+00$ & $0.000 \mathrm{E}+00$ \\
\hline & $R \mathrm{~h}-103 \mathrm{~m} \rightarrow$ & 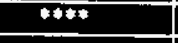 & & 60 & $0.000 \mathrm{E}+00$ & $0.000 \mathrm{E}+00$ \\
\hline & $R u-106 m$ & & & & $0.000 \mathrm{E}+00$ & $0.000 \mathrm{E}+00$ \\
\hline & Rh-106-..> & 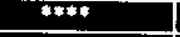 & & $+\infty$ & $0.000 \mathrm{E}+00$ & $0.000 \mathrm{E}+00$ \\
\hline & $P d-107 \ldots$ & & & & $0.000 \mathrm{E}+00$ & $0.000 \mathrm{E}+00$ \\
\hline & $\mathrm{Cd}-109 \longrightarrow$ & & & & $0.000 \mathrm{E}+00$ & $0.000 \mathrm{~B}+00$ \\
\hline & As $-110 \mathrm{~m} \rightarrow$ & & & & $0.000 \mathrm{~B}+00$ & $0.000 \mathrm{E}+00$ \\
\hline & $\mathrm{Ag} \cdot 110 \longrightarrow$ & 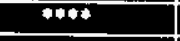 & & $* * * *$ & $0.000 \mathrm{~B}+00$ & $0.000 \mathrm{E}+00$ \\
\hline & $5 n-113 m$ & & & & $0.000 \mathrm{~B}+00$ & $0.000 \mathrm{~B}+00$ \\
\hline & In-113mm-.>> & $+\infty$ & & ot.. & $0.000 \mathrm{E}+00$ & $0.000 \overline{\mathrm{E}}+00$ \\
\hline & Cd-113m $\cdots$ & & & & $0.000 \mathrm{E}+00$ & $0.000 \mathrm{~B}+00$ \\
\hline & Cd-115m-..> & & & & $0.000 \mathrm{E}+00$ & $0.000 \mathrm{E}+00$ \\
\hline & $\mathrm{Sn}-119 \mathrm{~m} \cdots$ & & & & $0.000 \mathrm{E}+00$ & $0.000 \mathrm{~B}+00$ \\
\hline & $\mathrm{Sn}-121 \mathrm{~m}-\ldots$ & & & & $0.000 \mathrm{E}+00$ & $0.000 \mathrm{~B}+00$ \\
\hline & Sn-123 $\ldots$ & & & & $0.000 \mathrm{E}+00$ & $0.000 \mathrm{E}+00$ \\
\hline & $T 0-123 \mathrm{~mm}$ & & & & $0.000 \mathrm{E}+00$ & $0.000 \mathrm{E}+00$ \\
\hline & $8 \mathrm{sb}-124 \ldots$ & & & & $0.000 \mathrm{E}+00$ & $0.000 \mathrm{~B}+00$ \\
\hline & $\mathrm{Sb}-125=$ & & & & $0.000 \mathrm{E}+00$ & $0.000 \mathrm{E}+00$ \\
\hline & To-125m $m$ & & & & $0.000 \mathrm{E}+00$ & $0.000 \mathrm{E}+00$ \\
\hline & Sn-126 & & & & $0.000 \mathrm{E}+60$ & $0.0002+00$ \\
\hline & $S b-126 m-\cdots$ & 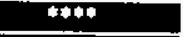 & & 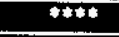 & $0.000 \mathrm{E}+00$ & $0.000 \mathrm{E}+00$ \\
\hline & $\mathrm{Sb}-126-->$ & & & & $0.000 \mathrm{~B}+00$ & $0.000 \mathrm{E}+00$ \\
\hline & To $127 \mathrm{~m}-\cdots$ & & & & $0.000 \mathrm{E}+00$ & $0.000 \mathrm{E}+00$ \\
\hline & Te-127- $->$ & 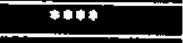 & & $\operatorname{ton}$ & $0.000 \mathrm{E}+00$ & $0.000 \mathrm{E}+00$ \\
\hline & To.129m $\rightarrow$ & & & & $0.000 \mathrm{E}+00$ & $0.000 \mathrm{E}+00$ \\
\hline & $T e-129 \cdots$ & $+* * *$ & & $7+100$ & $0.000 \mathrm{E}+00$ & $0.000 \mathrm{E}+00$ \\
\hline & I-129- & & & & $0.000 \mathrm{E}+00$ & $0.000 \mathrm{E}+00$ \\
\hline & $1-131 \cdots$ & & & & $0.000 \mathrm{E}+00$ & $0.000 \mathrm{E}+00$ \\
\hline & C..134-...> & & & & $0.000 \mathrm{E}+00$ & $0.000 \mathrm{E}+00$ \\
\hline & Cs-135-..- & & & & $0.000 \mathrm{E}+00$ & $0.000 \mathrm{E}+00$ \\
\hline
\end{tabular}


WHC-SD-TP-SEP-035 Rev. I

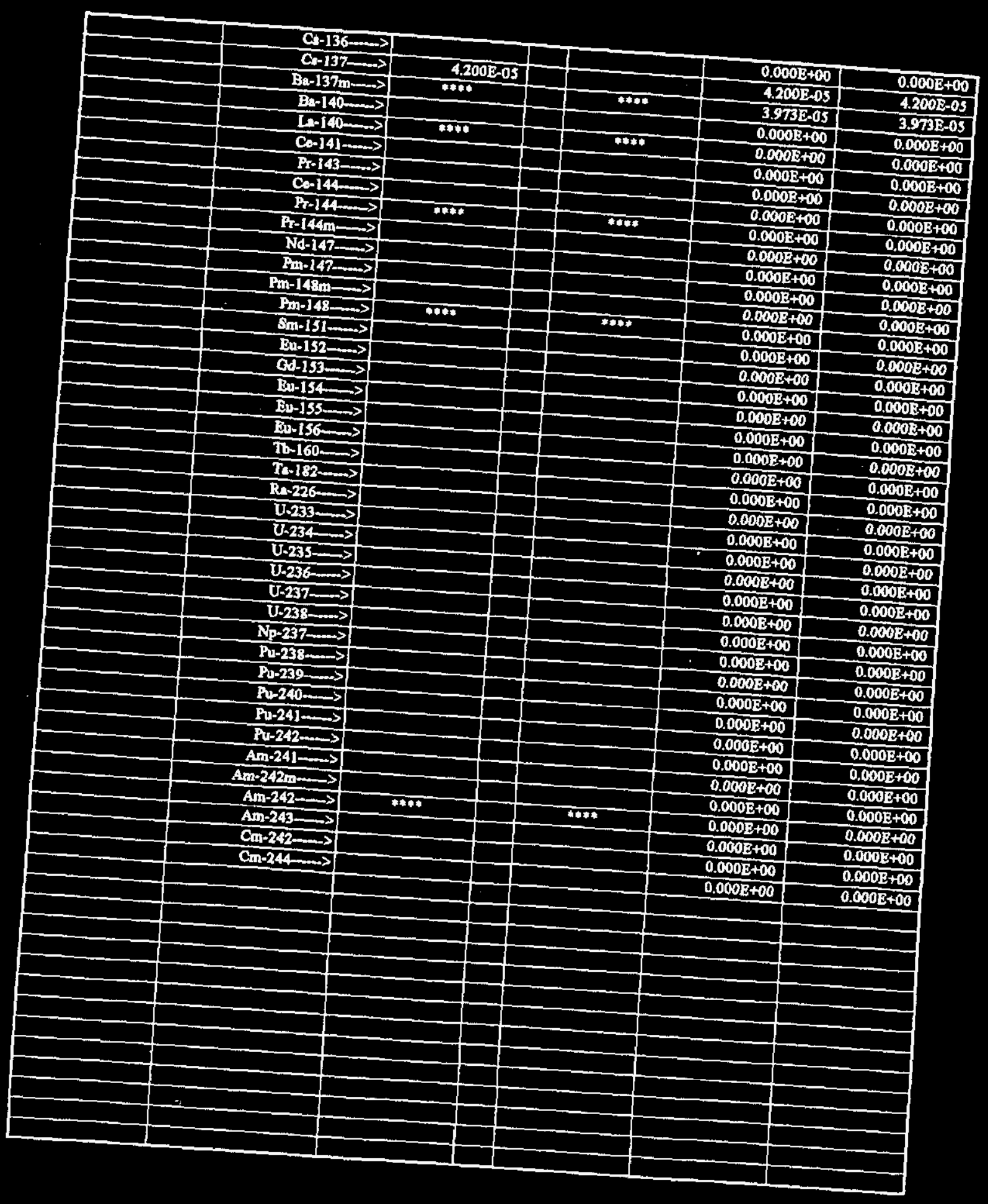

$B C-15$ 


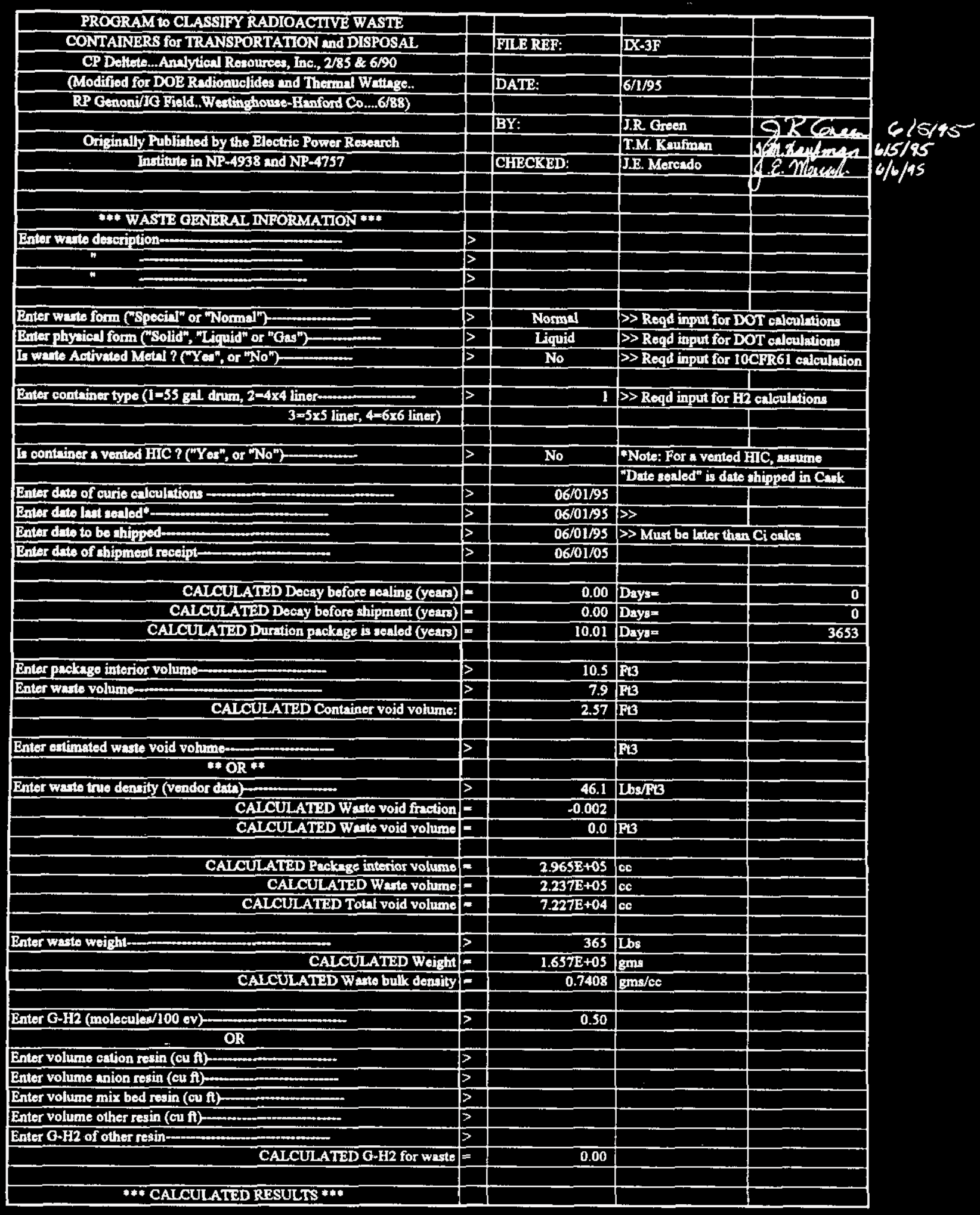




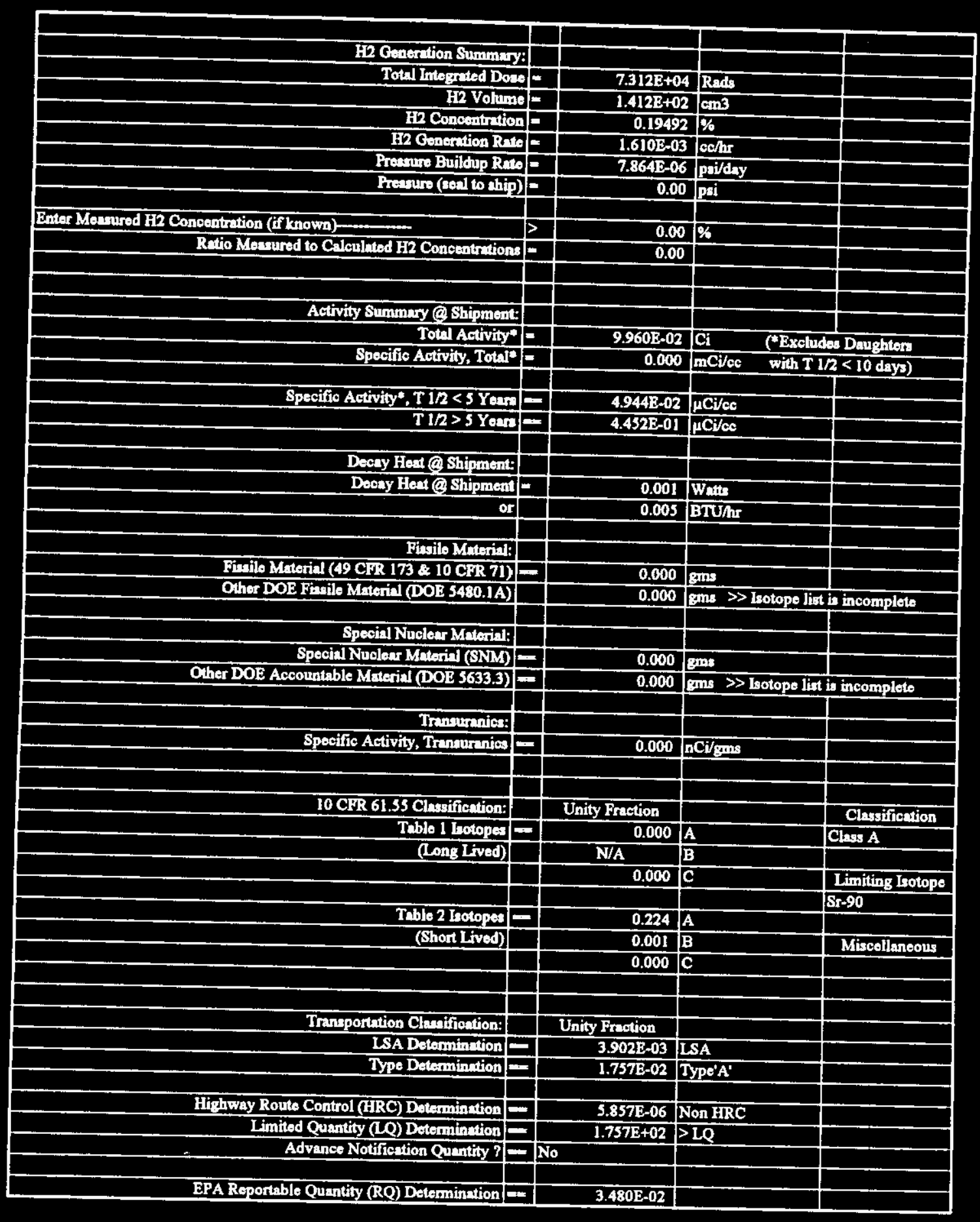




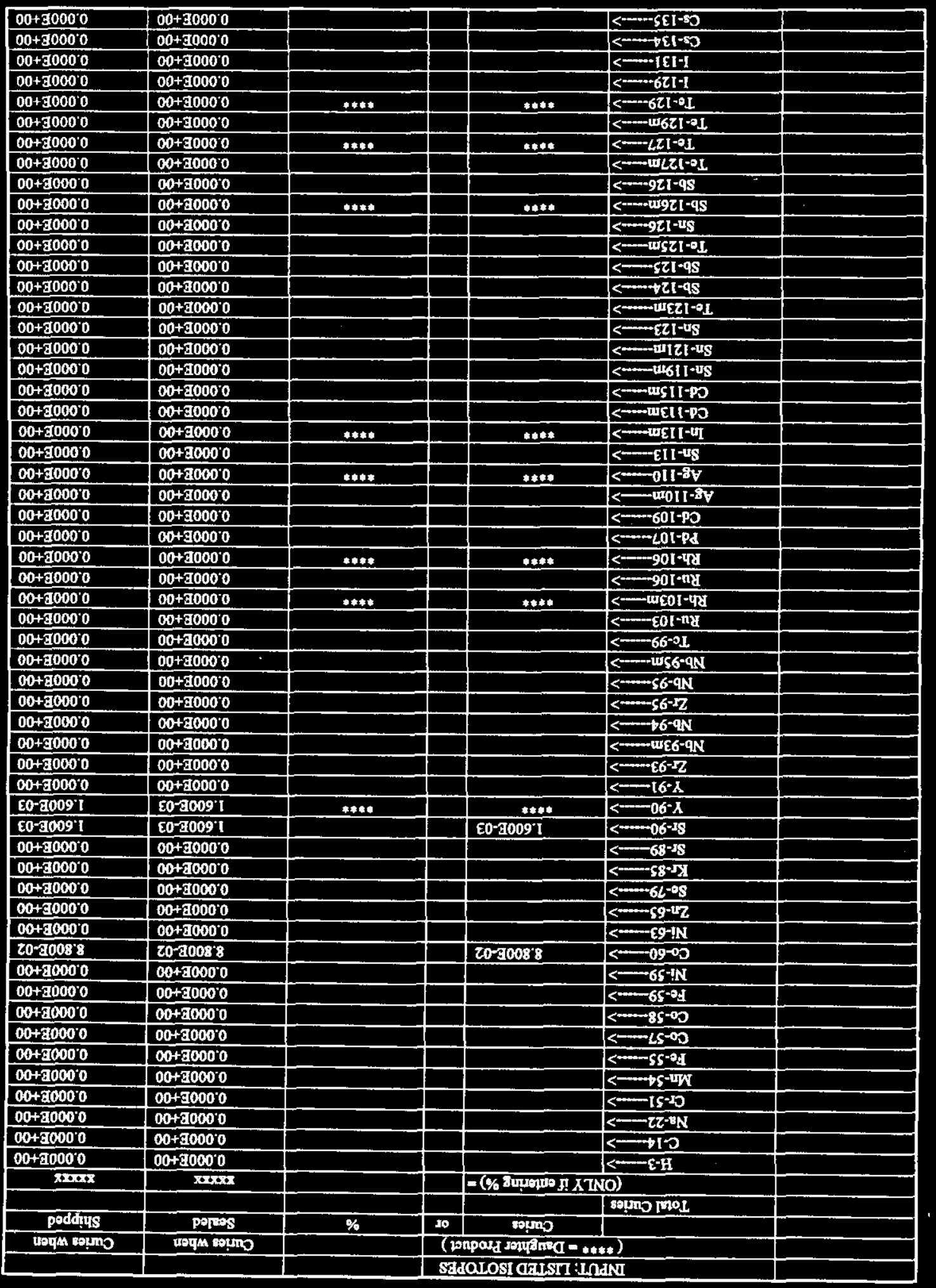




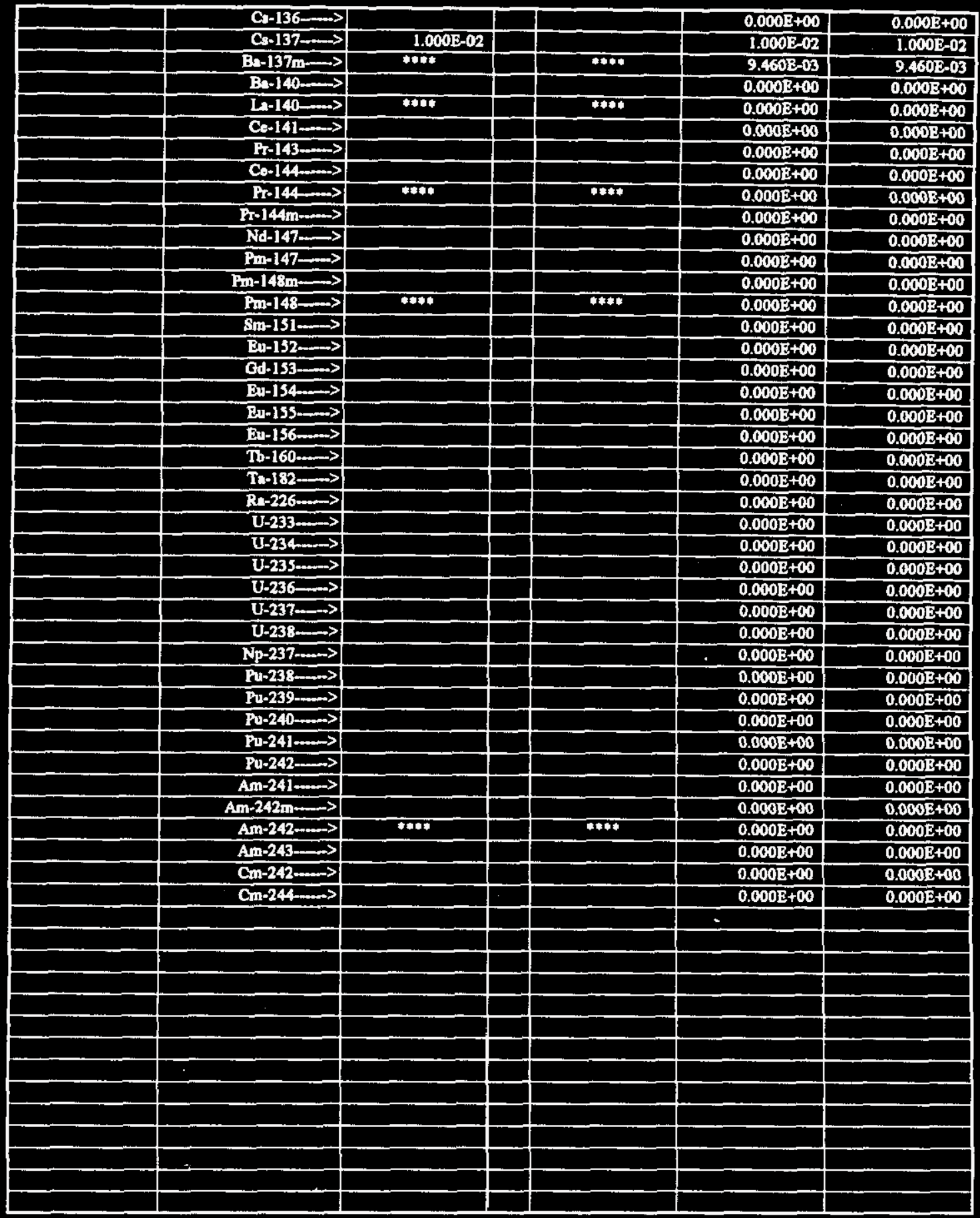




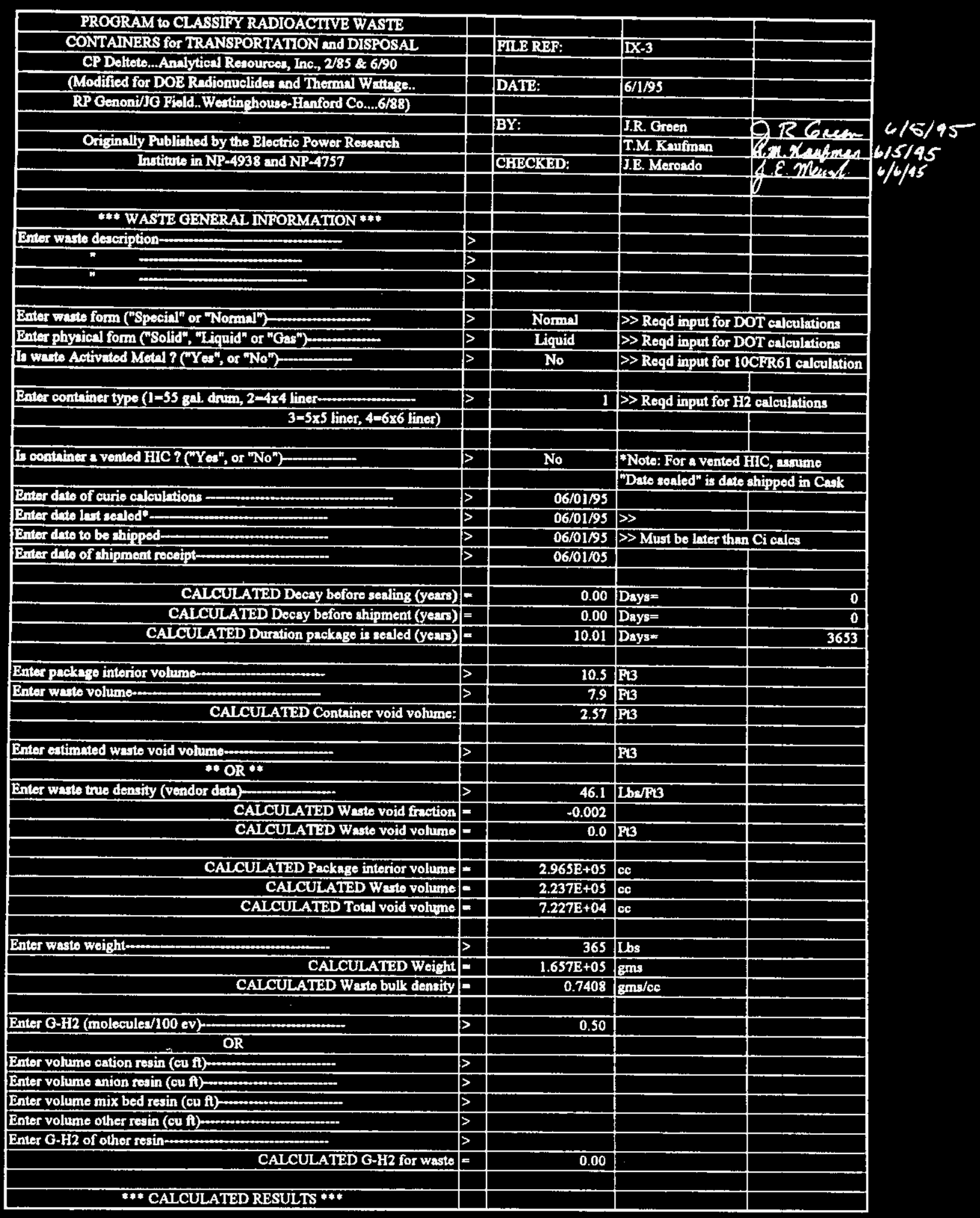




\begin{tabular}{|c|c|c|c|c|}
\hline \multicolumn{5}{|l|}{ H2 Generntion Summary: } \\
\hline Total Integrated Dose & E & $9.782 \mathrm{E}+02$ & Rads & \\
\hline H2 Volumio & $E$ & $1.888 \mathrm{E}+00$ & $\operatorname{com} 3$ & \\
\hline If Conoentration & $=$ & 0.00261 & $\%$ & \\
\hline H2 Generstion Rate & $=$ & $2.154 \mathrm{E}-05$ & ee/hr & \\
\hline Preasure Buildup Rate & $=$ & $1.052 \mathrm{E}-07$ & paiday & \\
\hline Presgure (cenl to ship) & $E$ & 0.00 & pai & \\
\hline & & & & \\
\hline Enter Meagured H2 Concontrition (fiknown) & \pm & 0.00 & $\%$ & \\
\hline Ratio Mernured to Calculated H2 Concentrations & 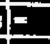 & 0.00 & & \\
\hline & & & & \\
\hline \multicolumn{5}{|l|}{ Activity Summery o Shipment: } \\
\hline Total Activity & E & $1.327 \mathrm{E}-03$ & \multicolumn{2}{|c|}{ ("Excludes Doughters } \\
\hline Specific Activity, Total & $E$ & 0.000 & \multicolumn{2}{|c|}{ mCi/cc with T $1 / 2<10$ daye } \\
\hline Specific Activity", T $1 / 2<3$ Youn & $=$ & $5.412 \mathrm{E}-04$ & $\mu \mathrm{Ci} / \Delta$ & \\
\hline $\mathrm{T} 1 / 2>5$ Yarn & $=$ & $5.932 \mathrm{E}-03$ & $\mu \mathrm{Ci} / \mathrm{cc}$ & \\
\hline & & & & \\
\hline \multicolumn{5}{|l|}{ Deony Hoat Q Shipment: } \\
\hline Decay Heat @ Shipment & $=$ & 0.000 & Watts & \\
\hline or & & 0.000 & BTUhr & \\
\hline & & & & \\
\hline \multicolumn{5}{|l|}{ Finsile Material: } \\
\hline Firalie Moterinl ( 49 CFR $173 \& 10$ CWR 71 ) & $=$ & 0.000 & \begin{tabular}{|l|l} 
Ems \\
\end{tabular} & \\
\hline Other DOE Finsilo Material (DOE S480.1A) & & 0.000 & \multicolumn{2}{|c|}{ Ens > Isotope list is incomplete } \\
\hline \multicolumn{5}{|l|}{ Specinl Nuolear Materini: } \\
\hline Special Nuclear Mnterial (GNM) & $=$ & 0.000 & gans & \\
\hline Other DOE Accountable Matetial (DOE 5633.3) & $=$ & 0.000 & \multicolumn{2}{|c|}{ gems $\gg$ Isotope list is incomplete } \\
\hline \multicolumn{5}{|l|}{ Tramsuranion: } \\
\hline Specific Activity, Transuranios & $=$ & 0.000 & $\mathrm{nC} \mathrm{ZZgms}_{\mathrm{gm}}$ & \\
\hline & & & & \\
\hline 10 CFR 61.53 Clansifiention: & & Unily Fraction & & Classification \\
\hline Tuble 1 lootoped & $=$ & 0.000 & A & Class A \\
\hline (Long Lived) & & N/A & B & \\
\hline & & 0.000 & C & Limiting Isotope \\
\hline & & & & Sr.90 \\
\hline Table 2 Inotoped & $=$ & 0.002 & A & \\
\hline (Bhort Lived) & & 0.000 & $\mathbf{B}$ & Mircellanoous \\
\hline & & 0.000 & (c & \\
\hline & & & & \\
\hline Transportation Clayifiantion: & & Unity Fruction & & \\
\hline LSA Determinatiog & $=$ & 4.687E-0S & LSA & \\
\hline Type Doleminution & 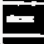 & $2.249 \mathrm{E} \cdot 04$ & Type'A & \\
\hline Highway Route Control (HRC) Dotermination & $=$ & $7.498 \mathrm{E}-08$ & Non HRC & \\
\hline Eimited Quantity (LO) Determination & $=$ & $2.249 \mathrm{E}+00$ & $>\mathrm{LQ}$ & \\
\hline Advance Notfication Quantity ? & $=$ & No & & \\
\hline EPA Repontable Quantity (RO) Detemination & $=$ & $4.000 \mathrm{E}-04$ & & \\
\hline
\end{tabular}




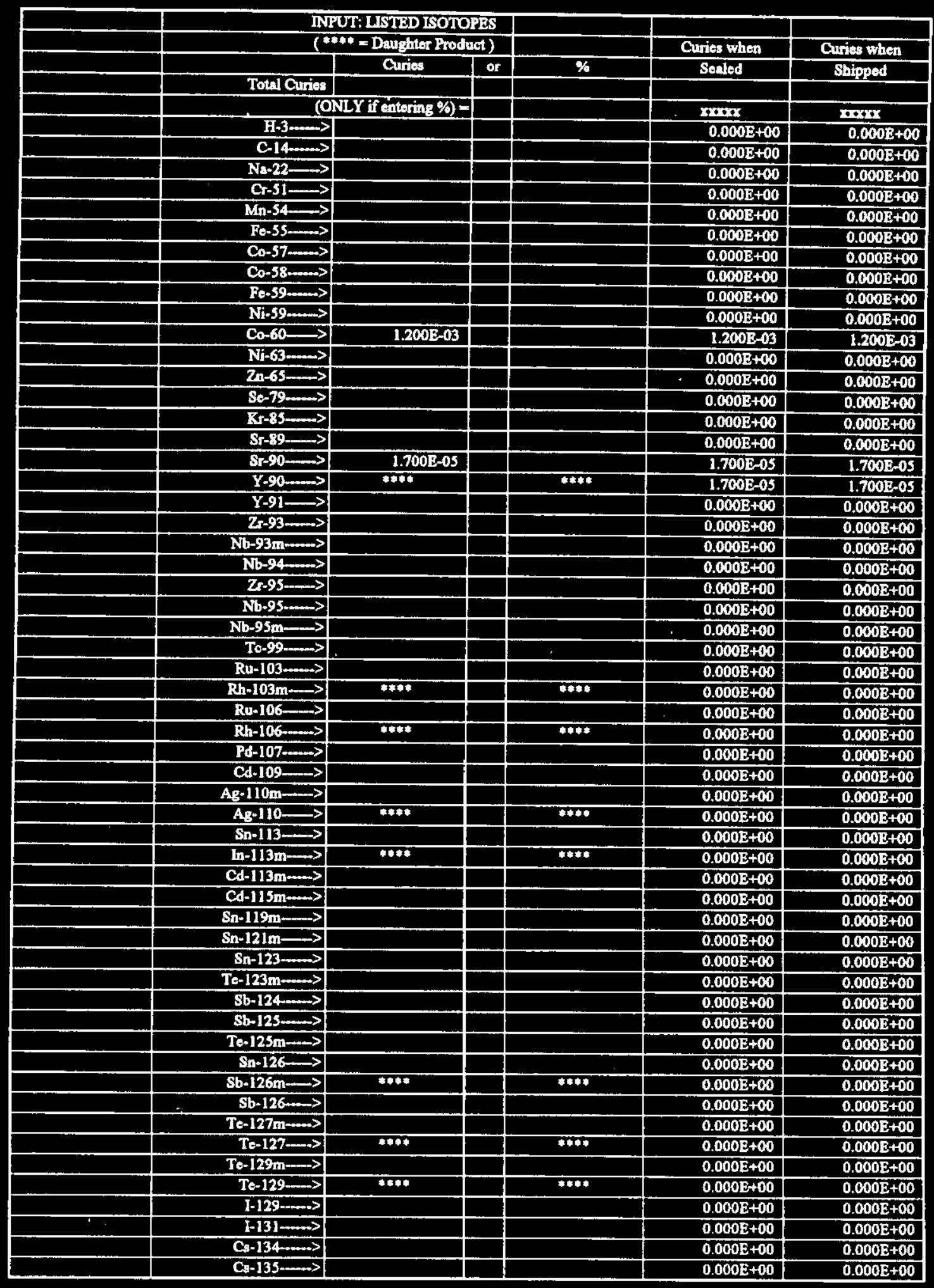


WHC-SD-TP-SEP-035 Rev. 1

\begin{tabular}{|c|c|c|c|c|c|c|}
\hline & C:-136- & & & $\because$ & $0.000 \mathrm{E}+00$ & $0.000 \mathrm{~B}+00$ \\
\hline & $C_{3}-137 \longrightarrow$ & $1.100 \bar{E}-04$ & & & $1.100 \mathrm{D}-04$ & $1.100 \mathrm{~g}-04$ \\
\hline & $B 8-137 m m$ & men: & & 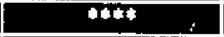 & $1.041 \mathrm{E}-04$ & $1.041 \mathrm{E}-04$ \\
\hline & $B a-140 \rightarrow-$ & & &. & $0.000 \mathrm{~B}+00$ & $0.000 \mathrm{~B}+00$ \\
\hline & 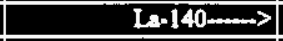 & 200: & & toter & $0.000 \mathrm{~B}+00$ & $0.000 \mathrm{E}+00$ \\
\hline & Ce-141 $\longrightarrow$ & & & & $0.000 \mathrm{E}+00$ & $0.000 \mathrm{~B}+00$ \\
\hline & Pro143 & & & & $0.000 \mathrm{E}+00$ & $0.000 \mathrm{~B}+00$ \\
\hline & Co-144 $\longrightarrow$ & & & & $0.000 \mathrm{~B}+00$ & $0.000 \mathrm{E}+00$ \\
\hline & $P_{r}-144 \longrightarrow$ & 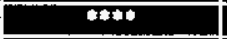 & & $90<$ & $0.000 \mathrm{E}+00$ & $0.000 \mathrm{E}+00$ \\
\hline & Pro144m $m$ & & & & $0.000 \mathrm{E}+00$ & $0.000 \mathrm{~B}+00$ \\
\hline & Nd-147 > & & & & $0.000 \mathrm{~B}+00$ & $0.000 \mathrm{E}+00$ \\
\hline & $\mathrm{Pm}-147 \mathrm{~m}$ & & & & $0.000 \mathrm{E}+00$ & $0.000 \mathrm{~B}+00$ \\
\hline & $\mathrm{Pm}-148 \mathrm{~m}=\ldots$ & & & & $0.000 \mathrm{E}+00$ & $0.000 B+60$ \\
\hline & $\mathrm{Pm}_{m-148} \longrightarrow$ & 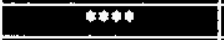 & & 1*t* & $0.000 \mathrm{E}+00$ & $0.0003+00$ \\
\hline & $8 m-151-00$ & & & & $0.000 \mathrm{~B}+00$ & $0.0002+00$ \\
\hline & $\mathrm{Eu}-152 \longrightarrow$ & & & & $0.000 \mathrm{~B}+00$ & $0.000 z+00$ \\
\hline & Gd-153 $\rightarrow$ & & & & $0.000 \mathrm{E}+60$ & $0.0005+00$ \\
\hline & $\mathrm{Bu} \cdot 154 \rightarrow$ & & & & $0.000 \mathrm{E}+\infty$ & $0.000 \mathrm{E}+00$ \\
\hline & Eu-155- $-\rightarrow$ & & & & $0.000 \mathrm{E}+00$ & $0.000 \mathrm{~B}+00$ \\
\hline & En-156-nes) & & & & $0.000 \mathrm{E}+00$ & $0.000 \mathrm{~B}+00$ \\
\hline & $T b-160=0$ & & & & $0,000 \mathrm{E}+00$ & $0.000 \mathrm{E}+00$ \\
\hline & $T 2-182 \longrightarrow$ & & & & $0.000 \mathrm{E}+00$ & $0.000 \mathrm{E}+00$ \\
\hline & $\mathrm{Ba} a 226 \ldots$ & & & & $0.0002+00$ & $0.000 \mathrm{~B}+00$ \\
\hline & $0-233-\longrightarrow$ & & & & $0.000 \mathrm{E}+00$ & $0.000 \mathrm{E}+00$ \\
\hline & U-234-> & & & & $0.0002+00$ & $0.000 \mathrm{~B}+00$ \\
\hline & U-235 $>$ & & & & $0.000 \mathrm{E}+00$ & $0.0002+00$ \\
\hline & U.236 & & & & $0.000 \mathrm{~B}+00$ & $0.000 \mathrm{E}+00$ \\
\hline & U-237_ــ> & & & & $0.000 \mathrm{E}+00$ & $0.000 \mathrm{E}+00$ \\
\hline & $\mathrm{U}-238 \rightarrow$ & & & & $0.000 \mathrm{E}+00$ & $0.000 \mathrm{E}+00$ \\
\hline & $N p-237 \rightarrow$ & & & & . $\quad 0.0002+\infty 0$ & $0.000 \mathrm{E}+00$ \\
\hline & Pu-238_> & & & & $0.000 \mathrm{~B}+00$ & $0.000 \mathrm{E}+00$ \\
\hline & Pu-239._. & & & & $0.000 \mathrm{E}+00$ & $0.000 \mathrm{E}+00$ \\
\hline & $P u-240 \rightarrow-\longrightarrow$ & & & & $0.000 \mathrm{~B}+00$ & $0.000 \mathrm{E}+00$ \\
\hline & Pl-241 & & & & $0.000 \mathrm{E}+00$ & $0.000 \mathrm{~B}+00$ \\
\hline & Pu-242m-n & & & & $0.000 \mathrm{E}+00$ & $0.000 \mathrm{E}+00$ \\
\hline & $A m-241 \longrightarrow$ & & & & $0.000 \mathrm{E}+00$ & $0.000 \mathrm{E}+00$ \\
\hline & $A m-242 m-\longrightarrow$ & & & & $0.0005+00$ & $0.000 \mathrm{E}+00$ \\
\hline & An-242 $\rightarrow$ & 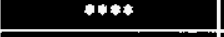 & & $* *$ & $0.000 \mathrm{E}+00$ & $0.000 \mathrm{~B}+00$ \\
\hline & Am-243 $->$ & & & & $0.000 \mathrm{E}+00$ & $0.000 \mathrm{E}+\infty 0$ \\
\hline & $C_{m-242}-\infty$ & & & & $0.000 \mathrm{~B}+00$ & $0.000 \mathrm{E}+00$ \\
\hline & Cm-244 & & & & $0.000 \mathrm{E}+00$ & $0.000 \mathrm{Z}+00$ \\
\hline & & & & & & \\
\hline & & & & & & \\
\hline & & & & & & \\
\hline & & & & & & \\
\hline & & & & & & \\
\hline & & & & & & \\
\hline & & & & & & \\
\hline & & & & & & \\
\hline & & & & & & \\
\hline & & & & & & \\
\hline & & & & & & \\
\hline & & & & & & \\
\hline & & & & & & \\
\hline & & & & & & \\
\hline
\end{tabular}




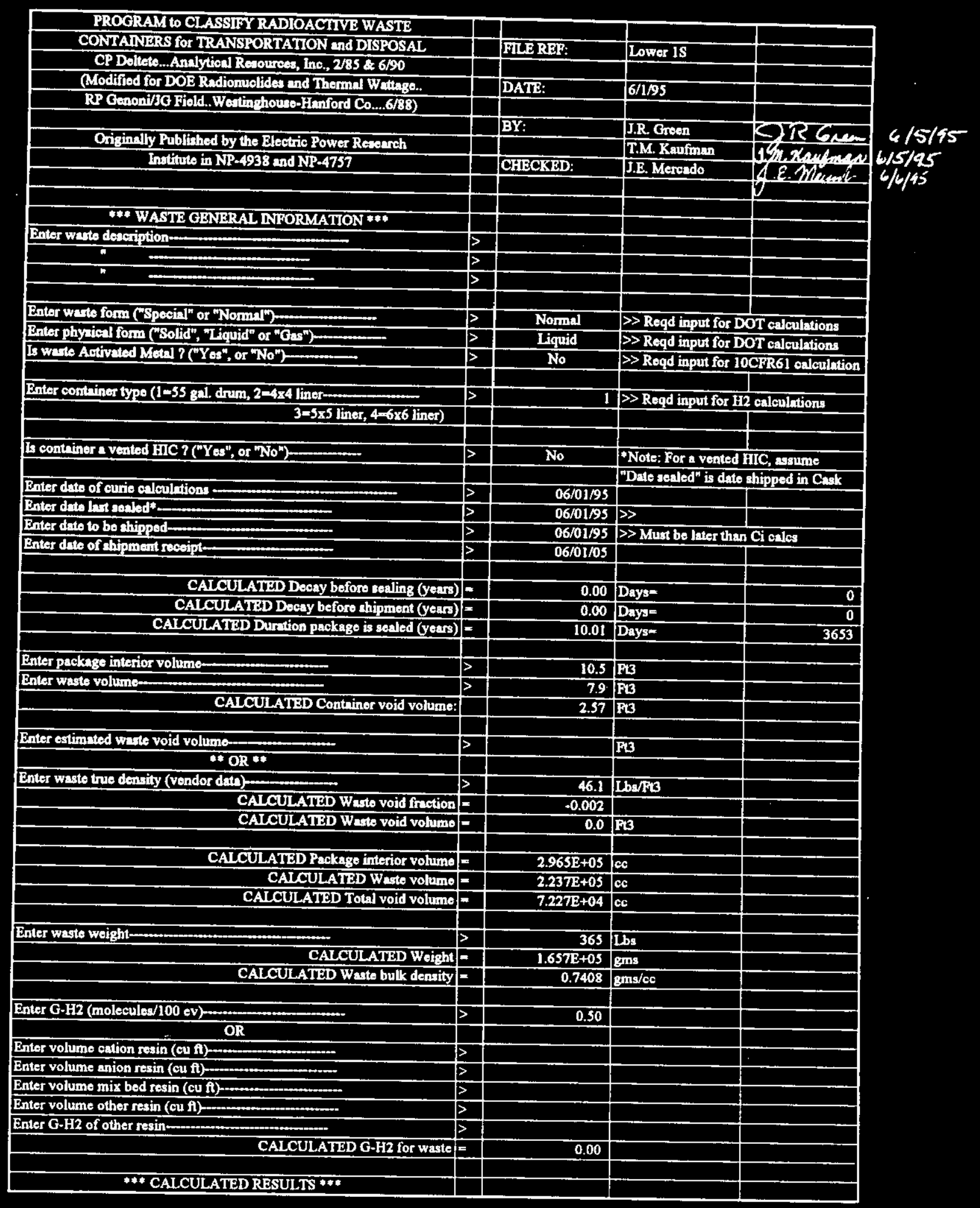




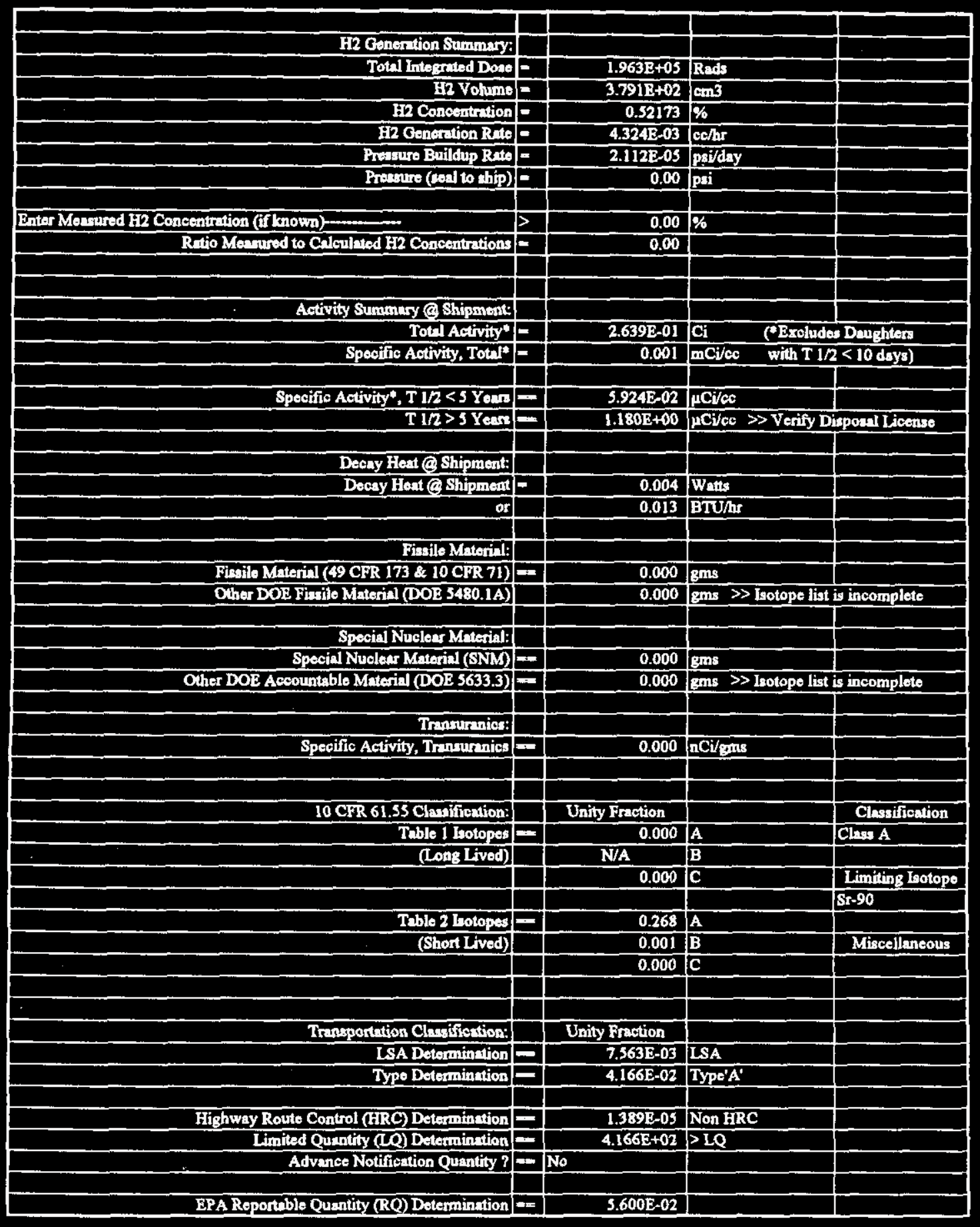




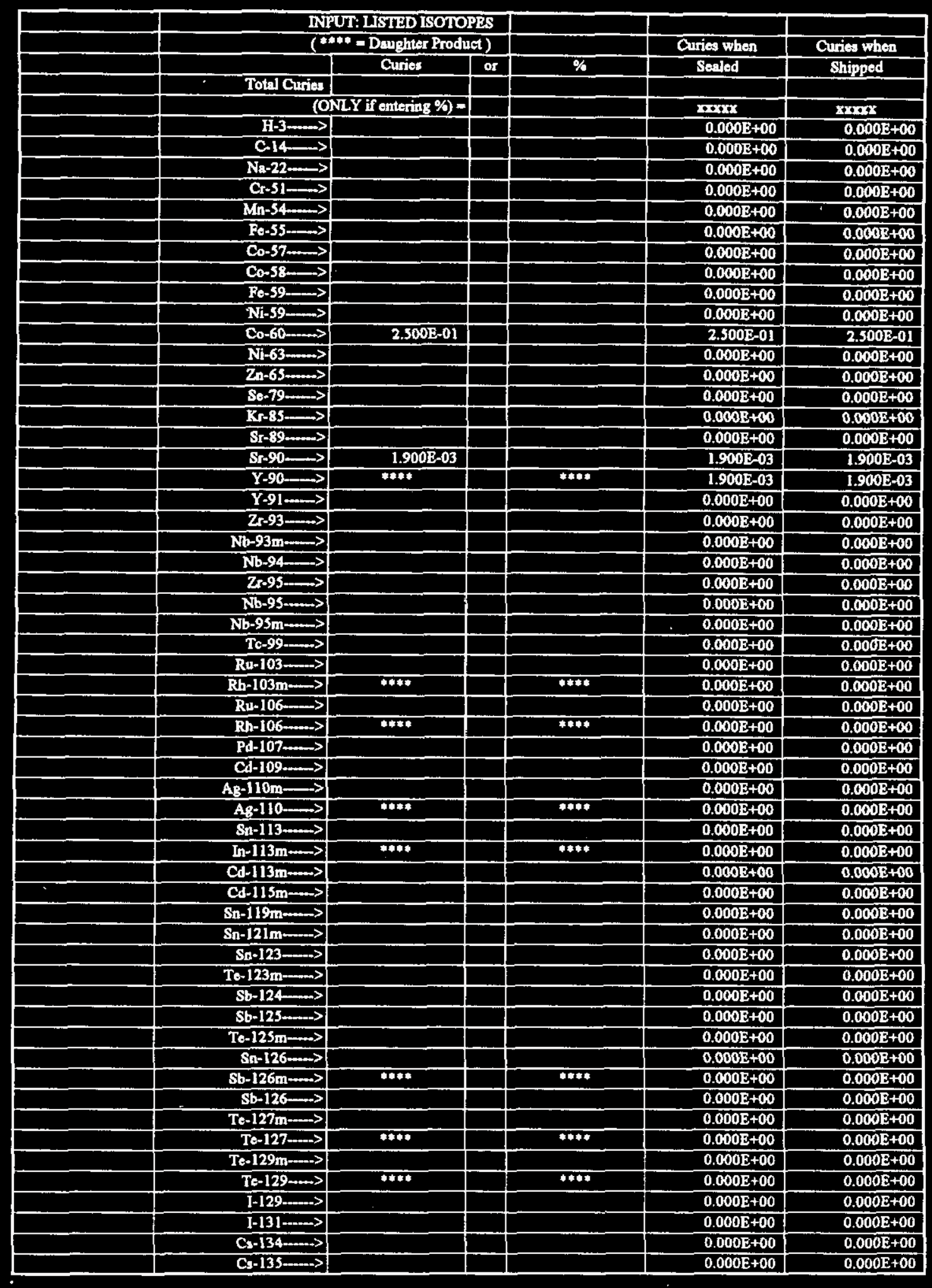


WHC-SD-TP-SEP-035 Rev. I

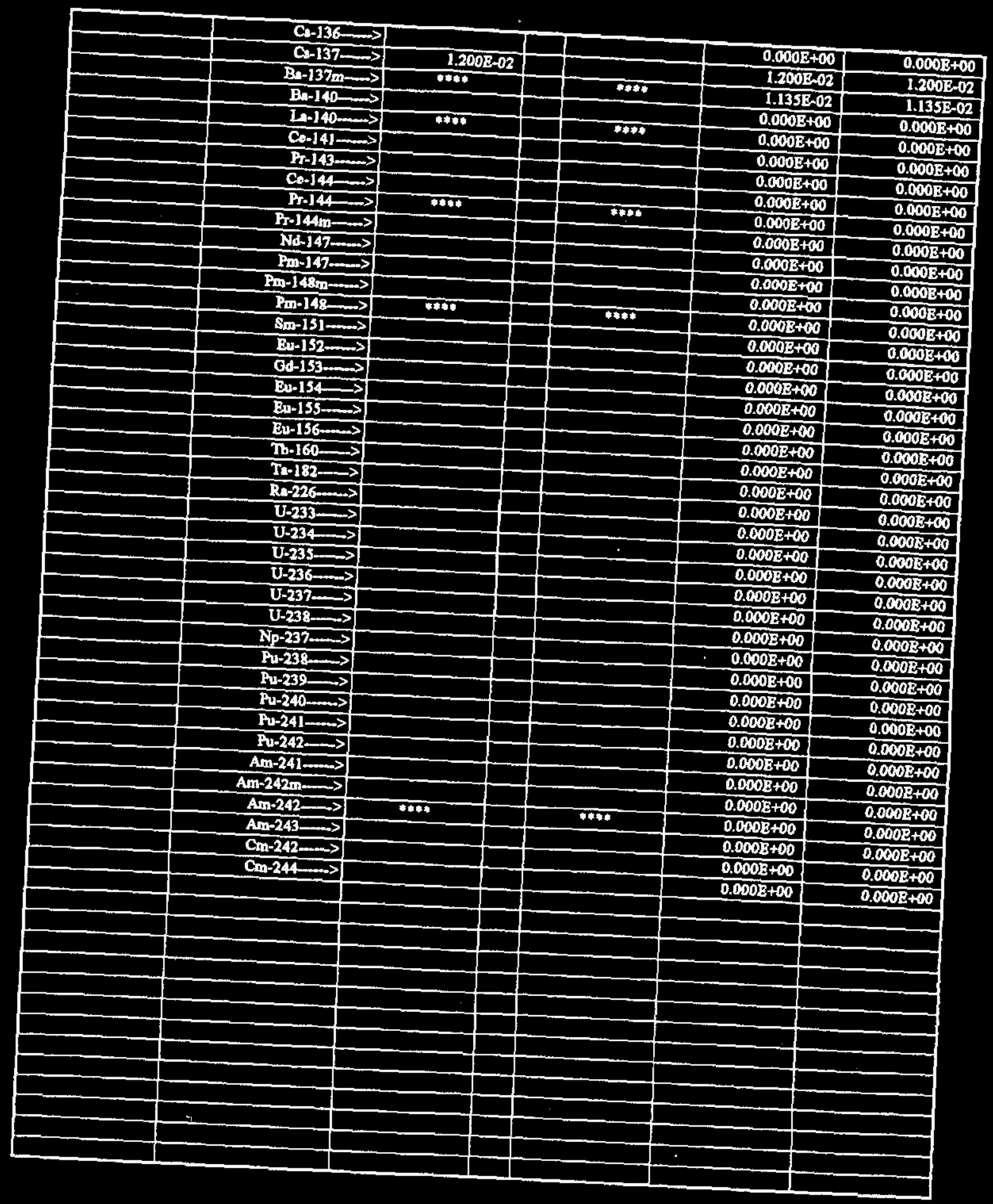

$B C-27$ 


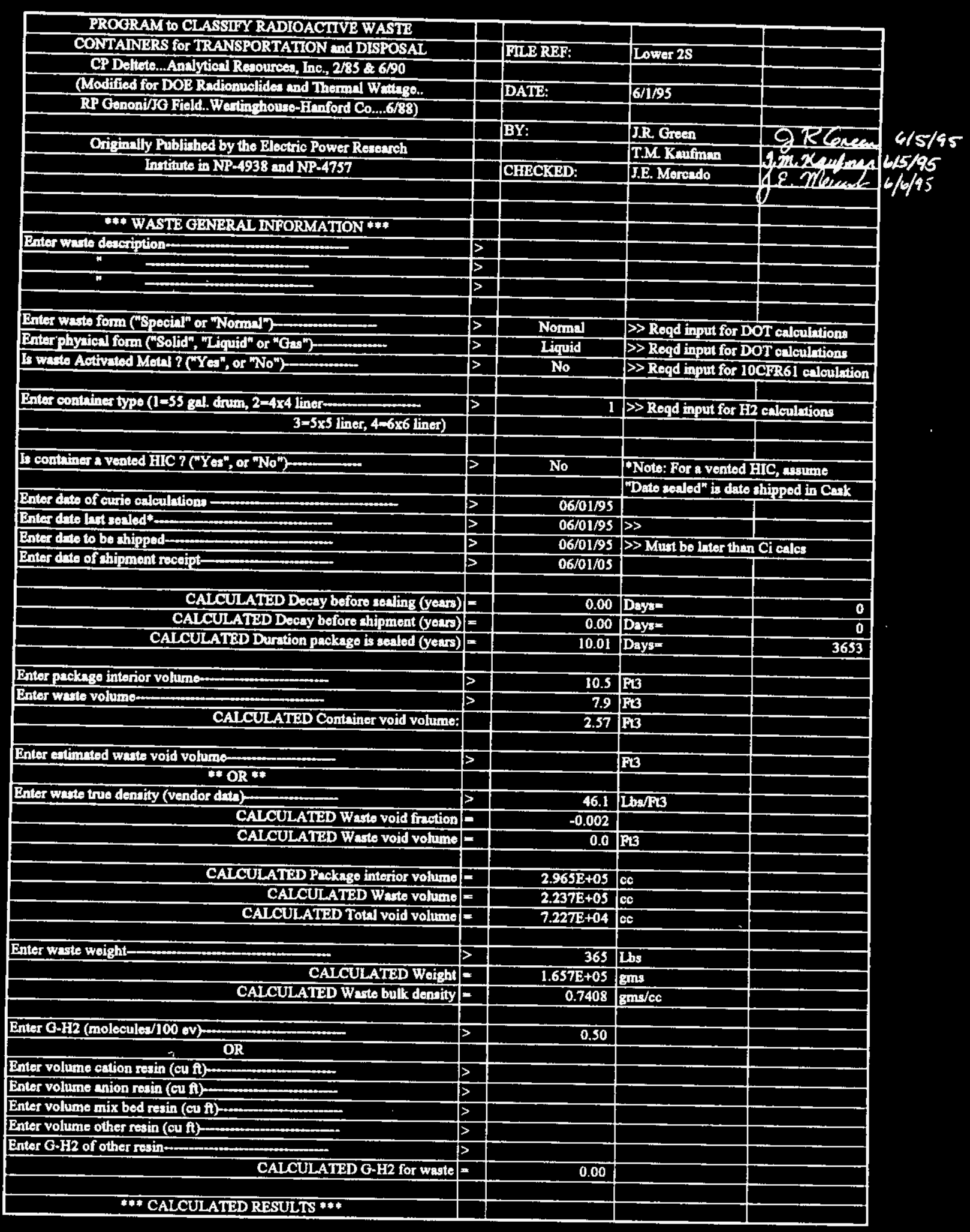




\section{WHC-SD-TP-SEP-035 Rev. I}

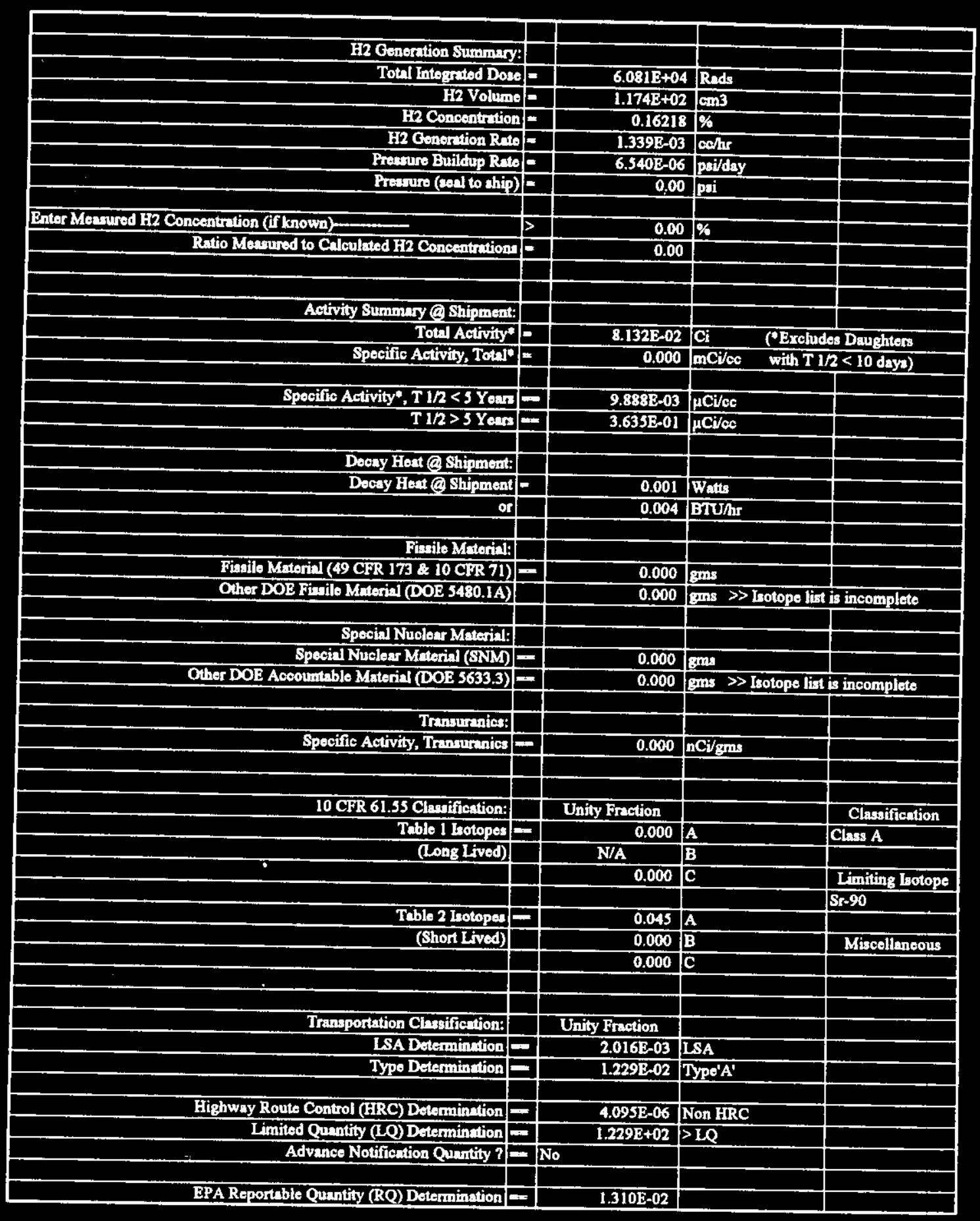


WHC-SD-TP-SEP-035 Rev, 1

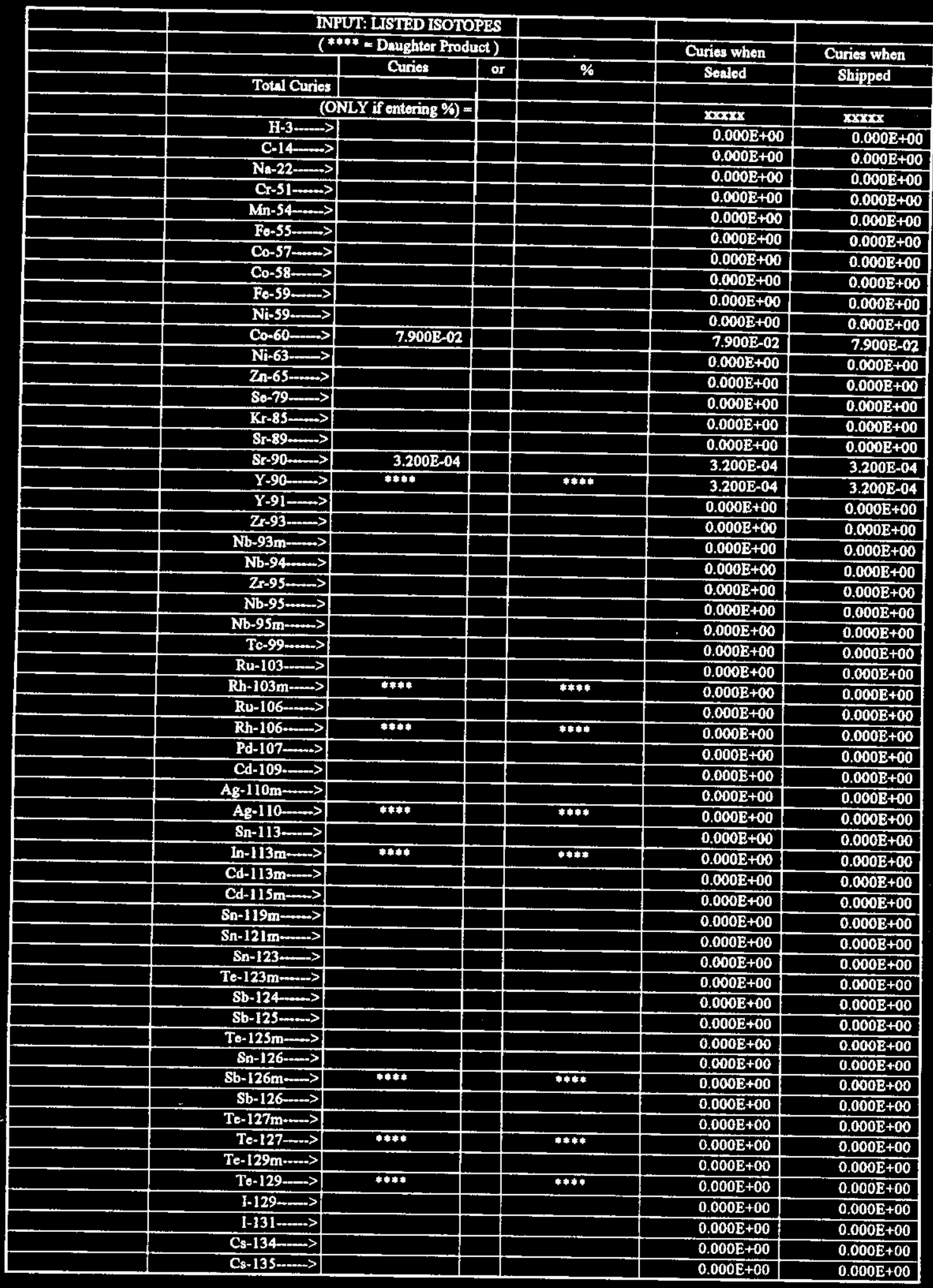




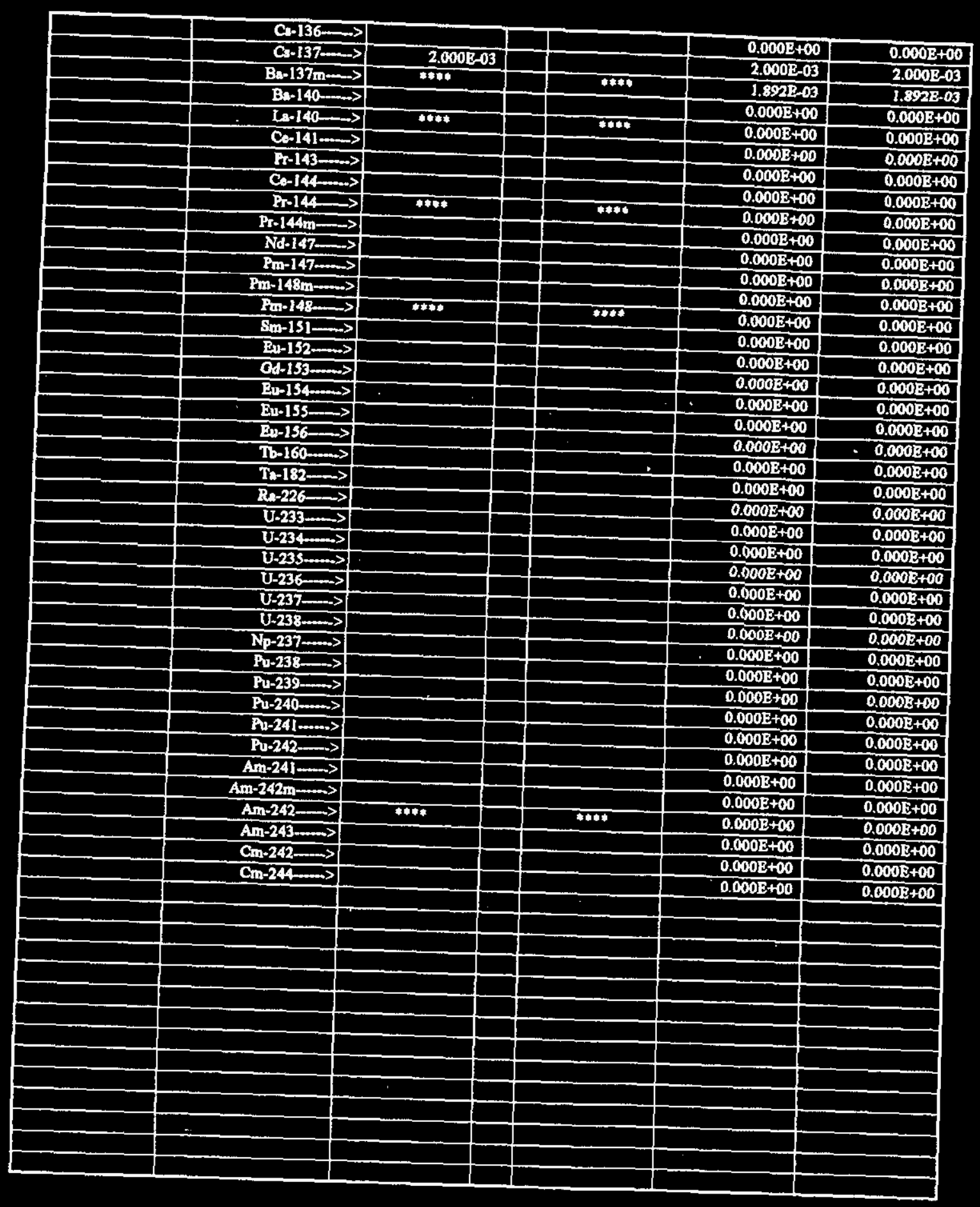




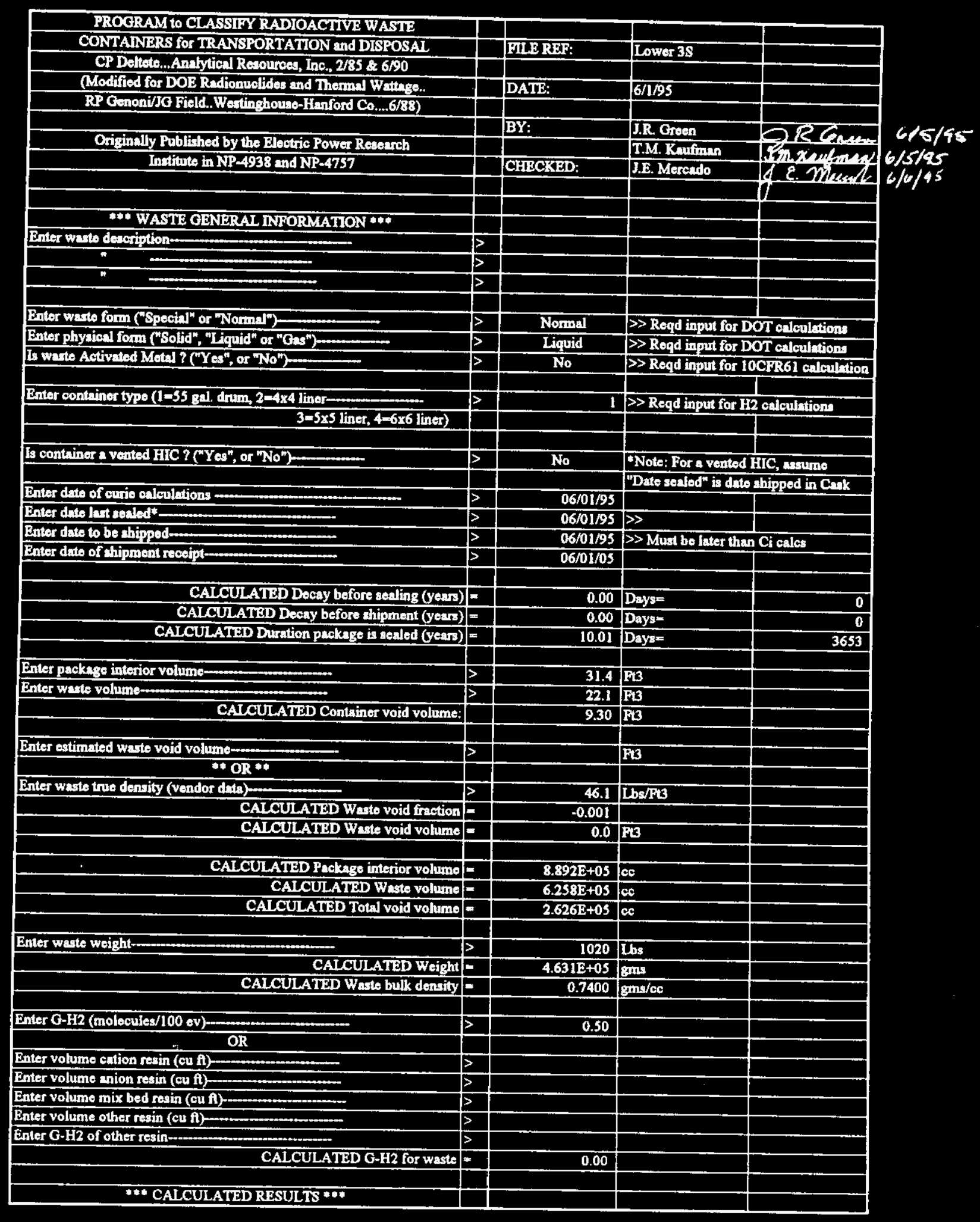




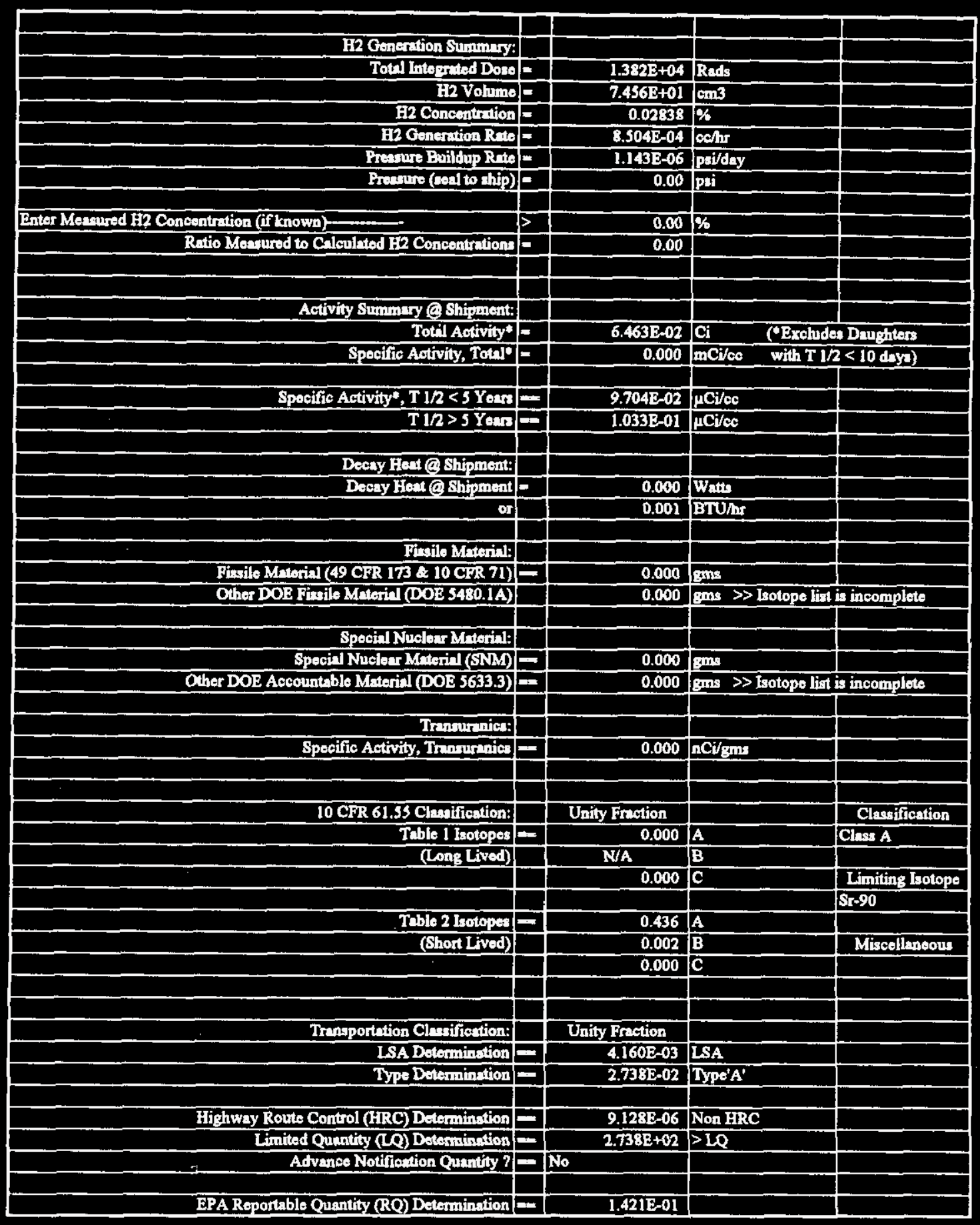




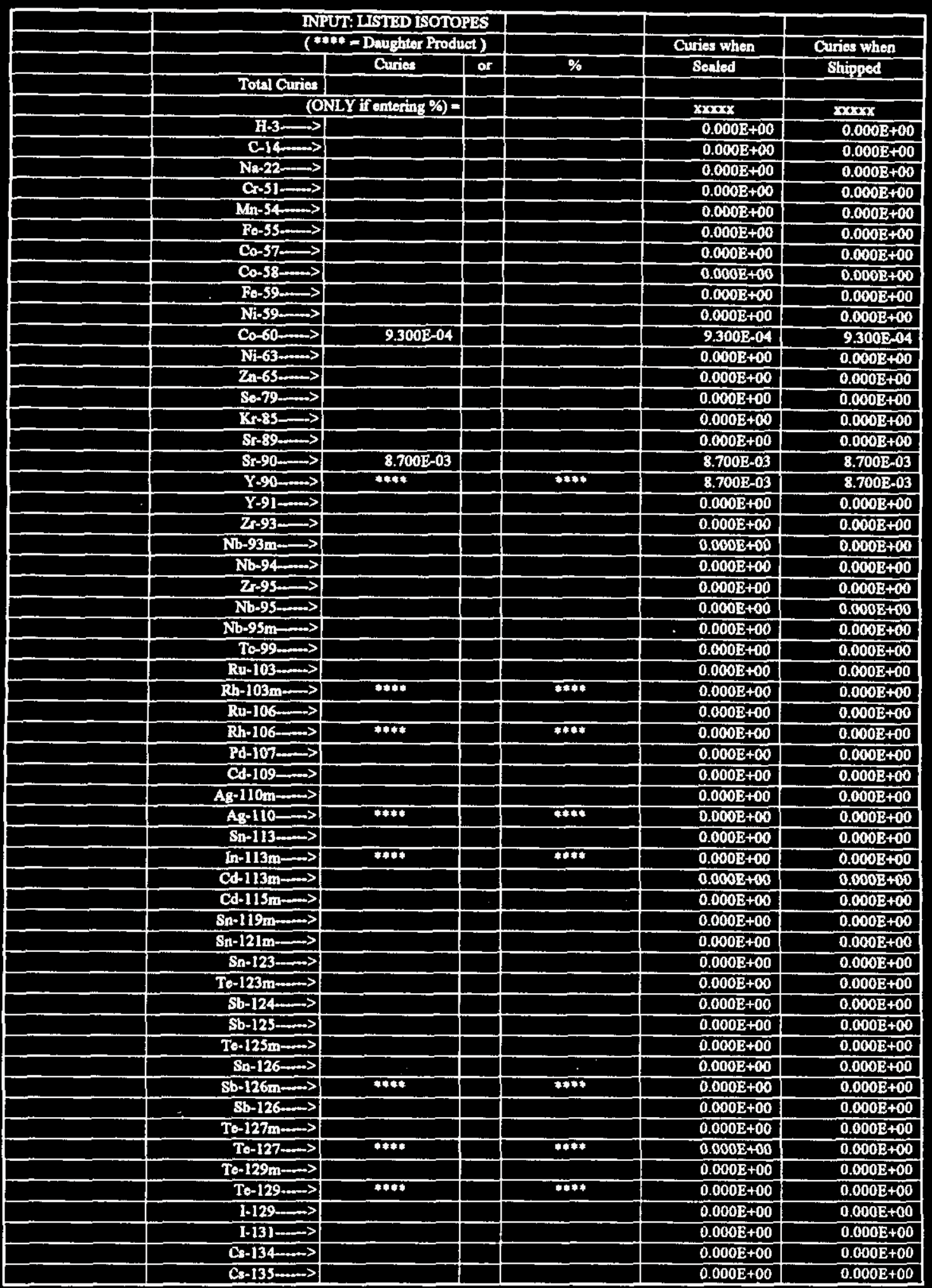




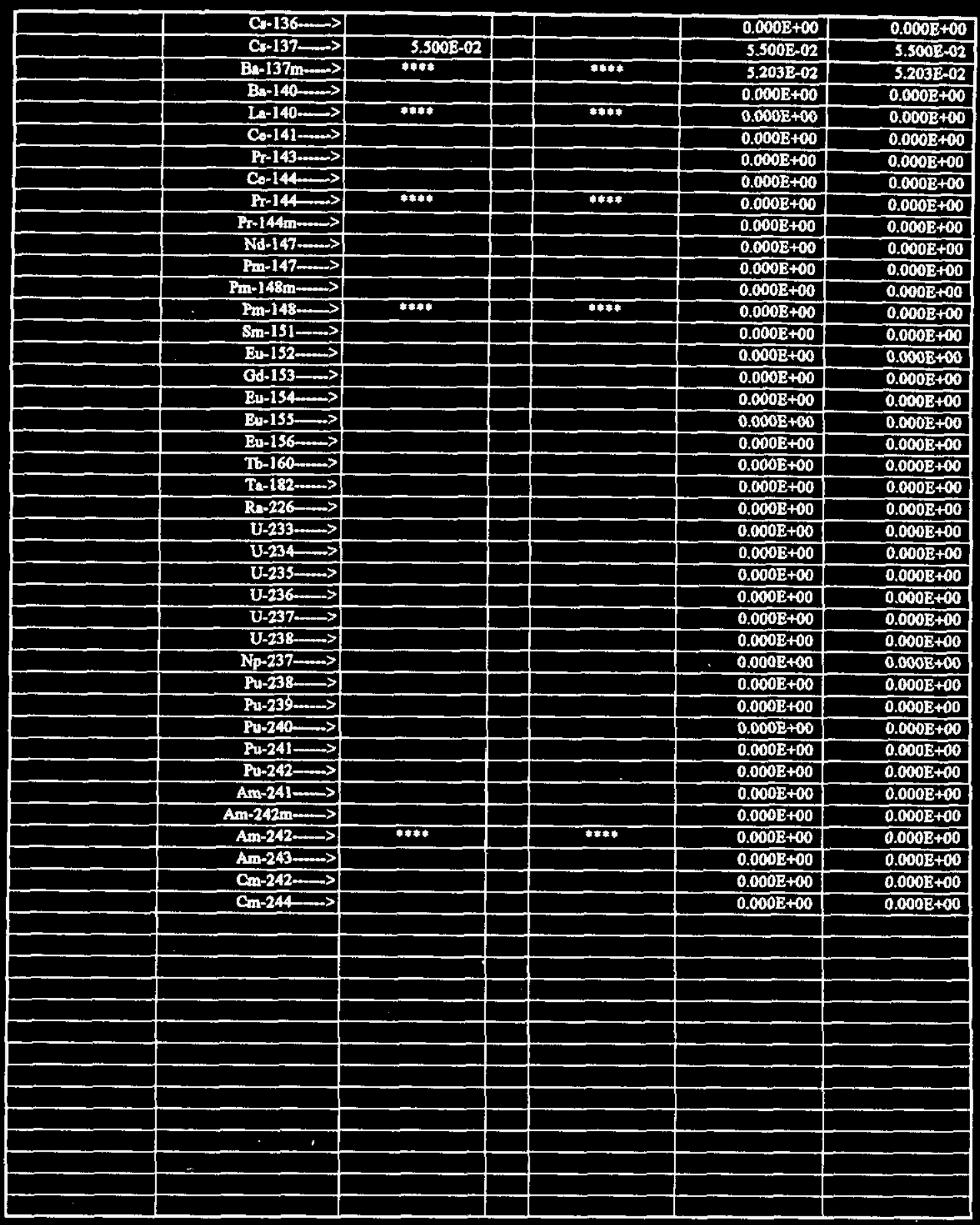

$B C-35$ 


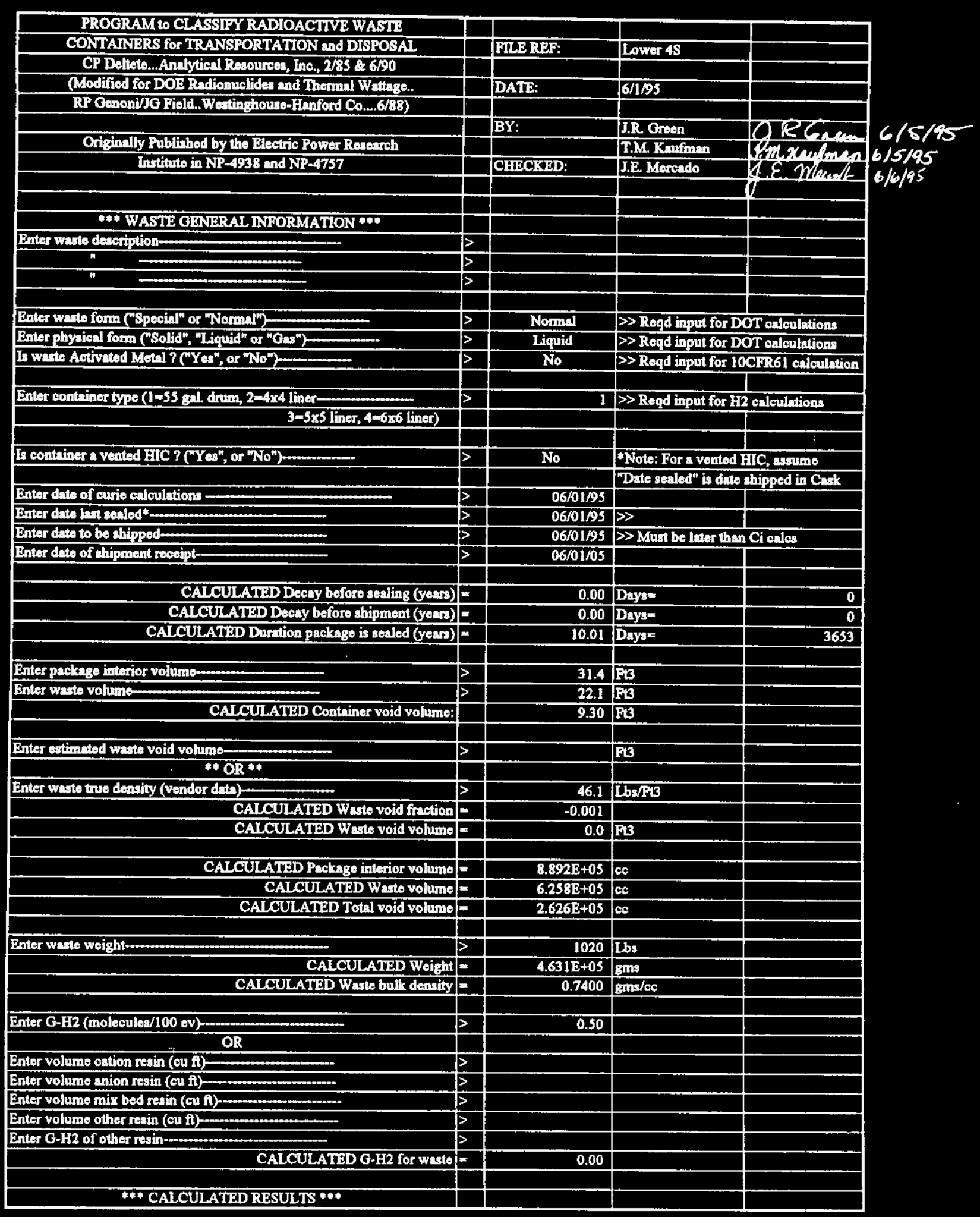


WHC-SD-TP-SEP-035 Rev. I

\begin{tabular}{|c|c|c|c|c|}
\hline \multicolumn{5}{|l|}{ H2 Genertion Summary: } \\
\hline Tothlinterasted Dose & $=$ & $8.231 \mathrm{E}+04$ & Redi & \\
\hline H2 Volume & 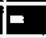 & $4.441 \mathrm{E}+02$ & $\operatorname{com} 3$ & \\
\hline H2 Concentrution & $=$ & 0.16881 & $\%$ & \\
\hline H2 Gonerstion Rnto & $=$ & $5.065 \mathrm{E}-03$ & $\infty$ & \\
\hline Prosenuse Buildup Rnto & $=$ & $6.8082-06$ & pai/day & \\
\hline Presure (cenl to ship) & 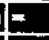 & 0.00 & $\mathrm{pi}$ & \\
\hline & & & & \\
\hline \multirow{4}{*}{ Retio Moaruned to Calculated H2 Concentrations } & $>$ & 0.00 & $\%$ & \\
\hline & e & 0.00 & & \\
\hline & & & & \\
\hline & & & & \\
\hline \multicolumn{5}{|l|}{ Aotivity Summary @ Shipment:- } \\
\hline Tot Activity & $E$ & $3.780 \mathrm{E}-01$ & \multirow{2}{*}{\multicolumn{2}{|c|}{$\begin{array}{l}\text { ("Brcludes Daughten } \\
\text { with T } 1 / 2<10 \text { dayo) }\end{array}$}} \\
\hline Specific Activity, Totns: & E & 0.001 & with T $1 / 2$ & \\
\hline Specinc Activity", T 1/2<3 Yound & $=$ & $5.3022-01$ & $\mu \mathrm{CV} / \mathrm{se}$ & \\
\hline T $1 / 2>5$ Yoars & 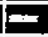 & $6.040 \mathrm{E}-01$ & HCHec & \\
\hline & & & & \\
\hline \multicolumn{5}{|l|}{ Deasy Hout @ Shipment: } \\
\hline Decey Hent @ Shipment & $=$ & 0.002 & Wata & \\
\hline or & & 0.008 & BTU/hr & \\
\hline & & & & \\
\hline \multicolumn{5}{|l|}{ Pbatile Material: } \\
\hline Fiasilo Ynterial ( 49 CFR 173 \& 10 CFR 71) & $=$ & 0.000 & 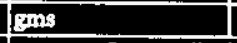 & \\
\hline Oher DOE Finsile Mnterial (DOE 5480.1A) & & 0.000 & \multicolumn{2}{|c|}{ Ems $\gg$ Isotope list is incomplete } \\
\hline \multicolumn{5}{|l|}{ Special Nucloar Mnterial: } \\
\hline Special Nuclenr Mnterial (SNM) & 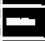 & 0.000 & $\operatorname{gans}$ & \\
\hline Other DOE Aceountable Material (DOE S633.3) & $=$ & 0.000 & \multicolumn{2}{|c|}{ gans $\gg$ Lotope list i incomplete } \\
\hline \multirow{2}{*}{\multicolumn{5}{|c|}{ Transuranica: }} \\
\hline & & & & \\
\hline Specinc Aotivity, Transuranios & $=$ & 0.000 & $\mathrm{nCi}$ gus & \\
\hline & & & & \\
\hline 10 CFR 61.55 Clanifiention: & & Unity Fraction & & Classification \\
\hline Table 1 Isotopes & $=$ & 0.000 & $\mathbf{A}$ & Clans B \\
\hline (Long Lived) & & N/A & $\mathbf{B}$ & \\
\hline & & 0.000 & $\mathbf{C}$ & Limiting Lotope \\
\hline & & & & $8 r-90$ \\
\hline Table 2 lotopes & $=$ & 2.398 & A & \\
\hline (Short Ived) & & 0.011 & $\mathrm{~B}$ & Miscellaneous \\
\hline & & 0.000 & C & \\
\hline & & & & \\
\hline Transportation Clantifamion: & & Unity Frnation & & \\
\hline LSA Determinntion & $=$ & $2.311 \mathrm{E}-02$ & LSA & \\
\hline Type Determination & $E$ & $1.543 \mathrm{E}-01$ & Type'A & \\
\hline & & & & \\
\hline Highway Routo Control (HRC) Determinution & - & $5.143 \mathrm{E}-0 \mathrm{~S}$ & Non HRC & \\
\hline Limited Qunntity (LQ) Determinution & $=$ & $1.543 \mathrm{E}+03$ & $>\mathbf{L}$ & \\
\hline Advance Notification Quantity ? & $=$ & No & & \\
\hline EPA Repartable Quantity (RQ) Determination & $=$ & $7.830 \mathrm{E}-01$ & & \\
\hline
\end{tabular}




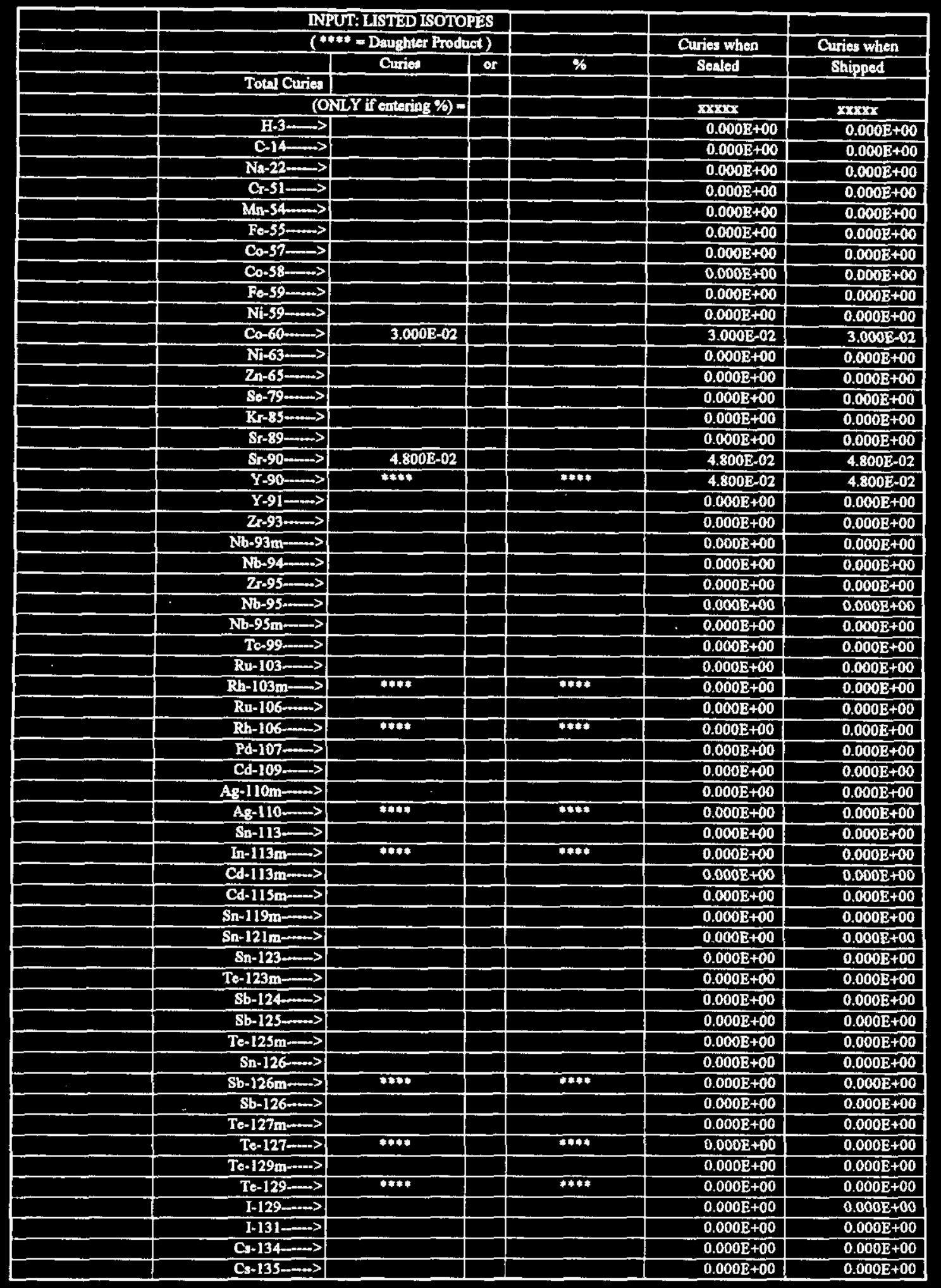


WHC-SD-TP-SEP-035 Rev. I

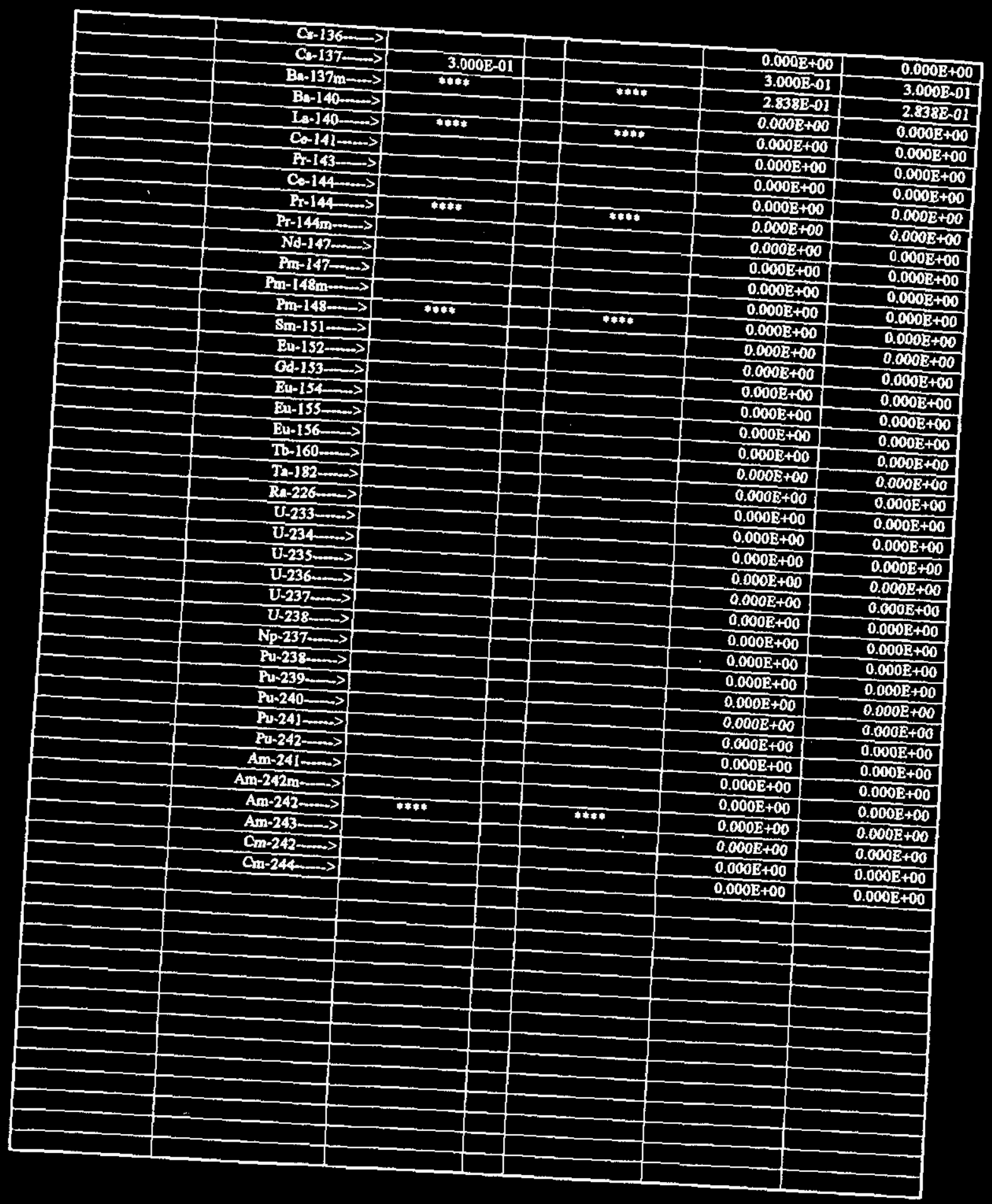




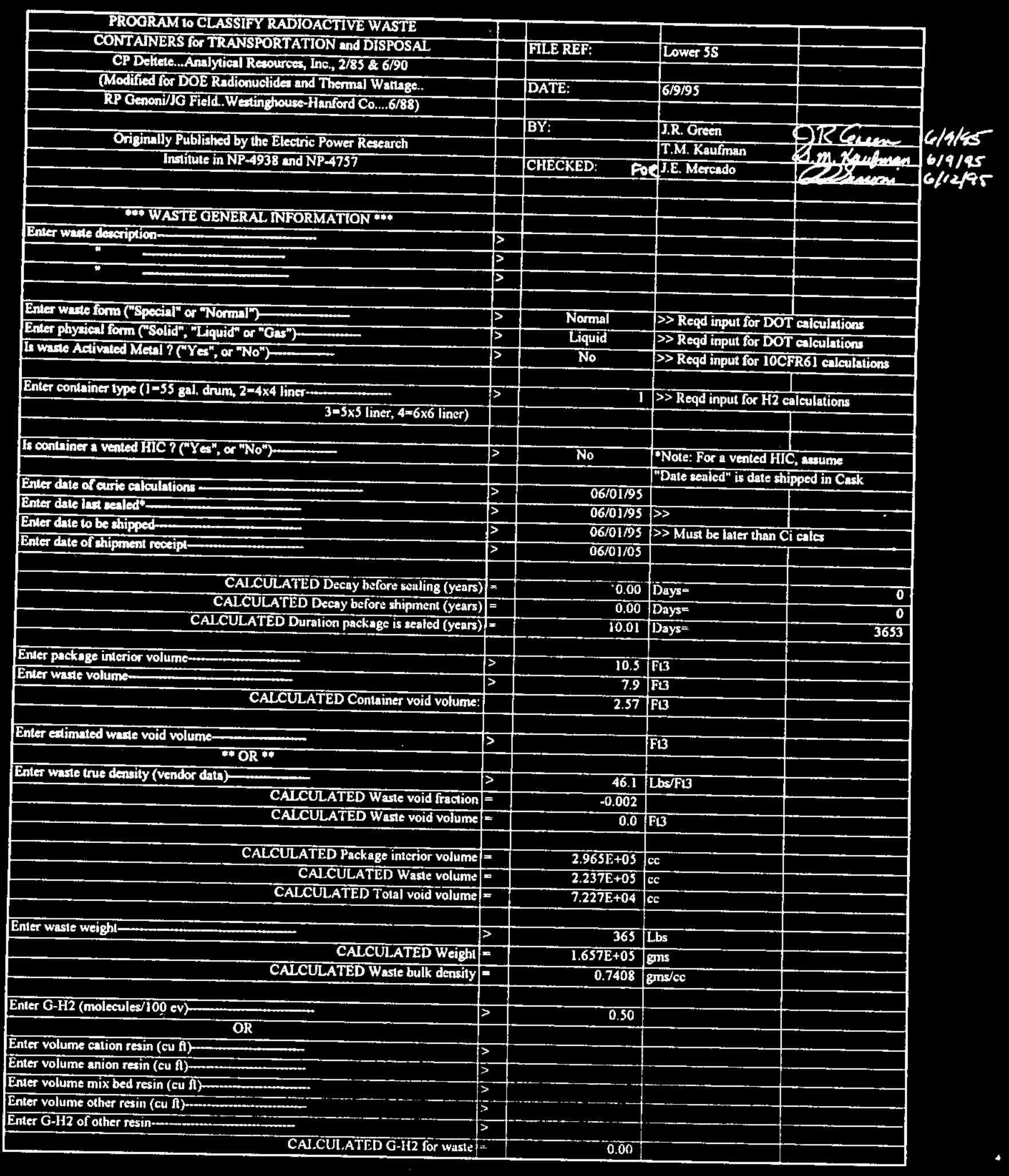




\begin{tabular}{|c|c|c|c|c|}
\hline & & & & \\
\hline CALCULATED RESULTS W" & & & & \\
\hline H2 Generation Surnmary: & & & & \\
\hline Total Integrated Dose & $=$ & $7.840 \mathrm{E}+04$ & Rads & \\
\hline $\mathrm{H}_{2}$ Volume & $=$ & $1.514 \mathrm{E}+02$ & $\mathrm{cm3}$ & \\
\hline F2 Concentration & $=$ & 0.20898 & $\%^{\circ}$ & \\
\hline H2 Generation Rale & $=$ & $1.726 \mathrm{E}-03$ & exhr & \\
\hline Presure Butldup Rote & $=$ & 8.4325 .06 & paiday & \\
\hline Preaure (ceal to ship), & $=$ & 0.00 & pai & \\
\hline Enter Meacared H2 Concentration (fiknown) & $>$ & 0.00 & $\%$ & \\
\hline Ratio Metsured to Calculated H2 Concentrations & $=$ & 0.00 & & \\
\hline & & & & \\
\hline & & & & \\
\hline Activity Summary @ Shipment: & & & & \\
\hline Total Activity & $=$ & $1.053 \mathrm{E}-01$ & (Fexclude Da & aughten \\
\hline Specific Activity, Total & E & 0.000 & with T $1 / 2<1$ & 10 days) \\
\hline Specilic Activity", T $/ 2<5$ Years & $=-\infty$ & $2.272 \mathrm{E}-02$ & $\mu \mathrm{Ci} / \mathrm{cc}$ & \\
\hline T $1 / 2>5$ Years & 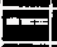 & $4.708 \mathrm{E}-01$ & IICi/cc & \\
\hline & & & & \\
\hline Decay Heat @ Shipment: & & & & \\
\hline Decay Heat @ Shipment & $=$ & 0.002 & Watts & \\
\hline or) & & 0.005 & BTUhr & \\
\hline & & & & \\
\hline $\begin{array}{c}\text { Fissile Material: } \\
\end{array}$ & & & & \\
\hline Fiswile Material (49 CFR 173\& $10 \mathrm{CFR} 71$ ) & $m=$ & 0.000 & \begin{tabular}{|l|l|} 
gons \\
\end{tabular} & \\
\hline OTher DOE Fissile Material (DOE S480.1A) & & 0.000 & Ems > Isolope list is in & necomplete \\
\hline Special Nuclear Material: & & & & \\
\hline Special Nuclear Material (SNM) & $= \pm=$ & 0.000 & gans & \\
\hline Othet DOE Accountable Mnterial (DOE 3633.3) & $= \pm$ & 0.000 & Ems $\gg$ Isotope list is in & reomplete \\
\hline Transuranics: & & & & \\
\hline Specific Aclivity, Transaranics & $=0$ & 0.000 & $\mathrm{nCi} / \mathrm{gms}$ & \\
\hline & & & & \\
\hline $10 \mathrm{CFR} 61.55$ Classification: & & Unily Fraction & & Classification \\
\hline Table I lsctopes & $== \pm$ & 0.000 & A & Class $\mathrm{A}$ \\
\hline (Long Lived) & & N/A & B & \\
\hline & & 0.000 & C & Limiting lsotope \\
\hline & & & & Sr-90 \\
\hline Table 2 lsolopes & 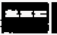 & 0.103 & $A$ & \\
\hline (Shon Lived) & & 0.000 & $\bar{B}$ & Miscellaneous \\
\hline & & 0.000 & $\mathrm{c}$ & \\
\hline & & & & \\
\hline Transportation Classification: & & Unity Fraction & & \\
\hline LSA Detennination & $=-1$ & 2.985E-03 & LSA & \\
\hline Type Deleminution & $=$ & $1.657 \mathrm{E}-02$ & Tyрк'A' & \\
\hline & & & & \\
\hline Highway Route Control (HRC) Determination & $t=$ & $5.524 \mathrm{E}-06$ & Non HRC & \\
\hline Limiled Quantity (LQ) Delermination & $\approx=$ & $1.657 \mathrm{E}+02$ & $>1.0$ & \\
\hline Advance Notification Quantily ? & $=x=$ & No & & \\
\hline EPA Reportsble Quantity (RQ) Dutermination & $==-$ & $2.190 \mathrm{E}-02$ & & \\
\hline
\end{tabular}


WHC-SD-TP-SEP-035 Rev, I

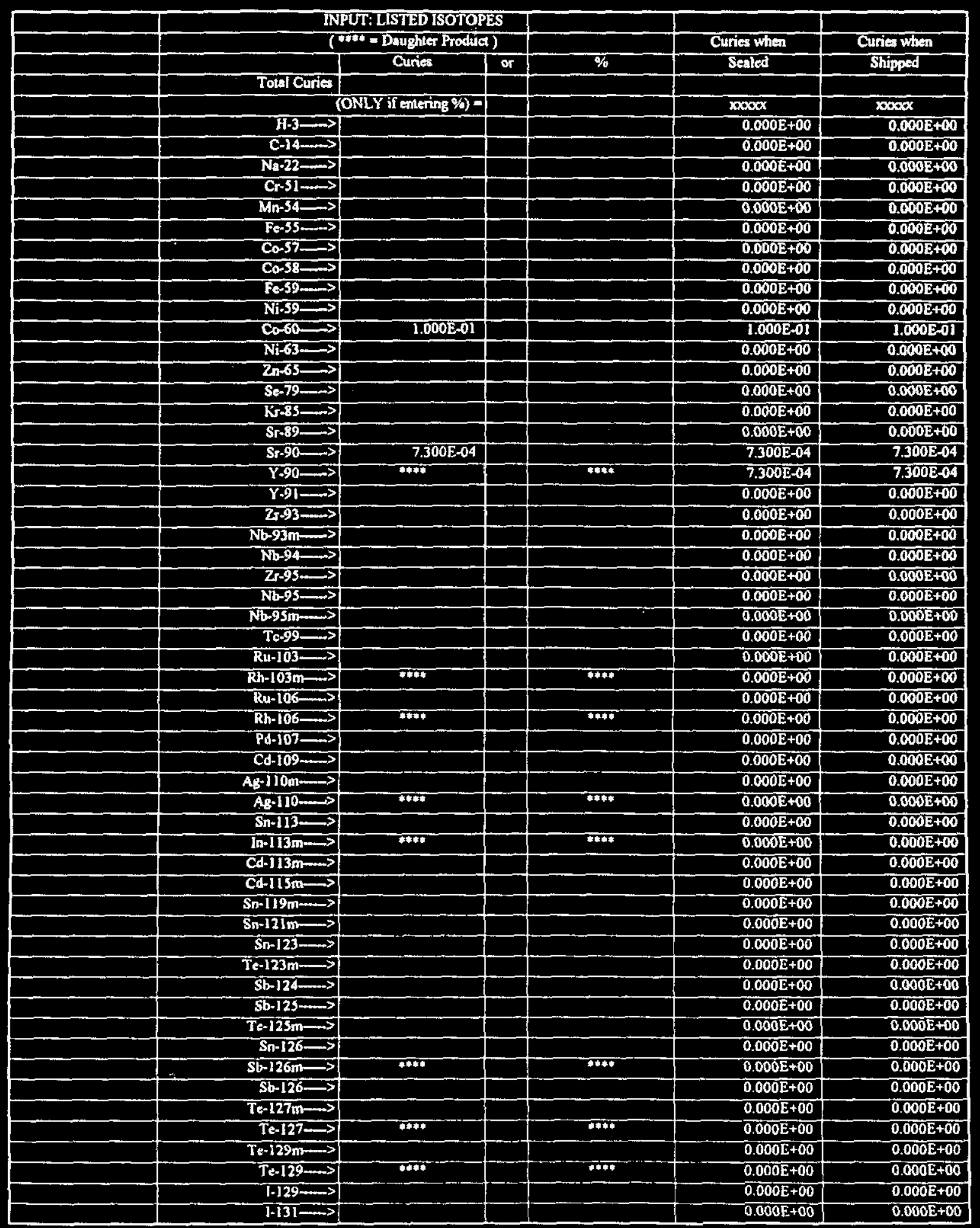


WHC-SD-TP-SEP-035 Rev. 1

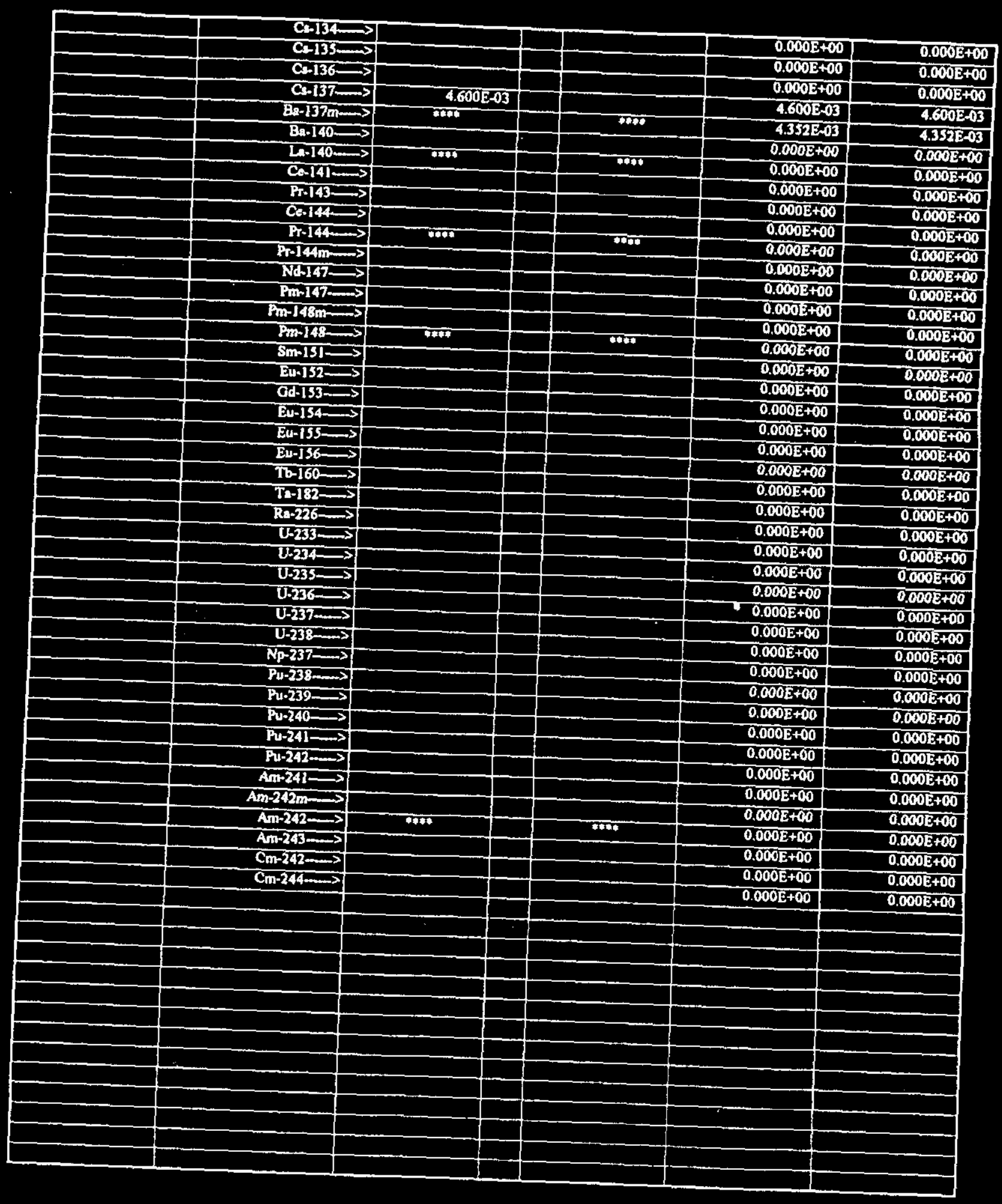

$B C-43$ 


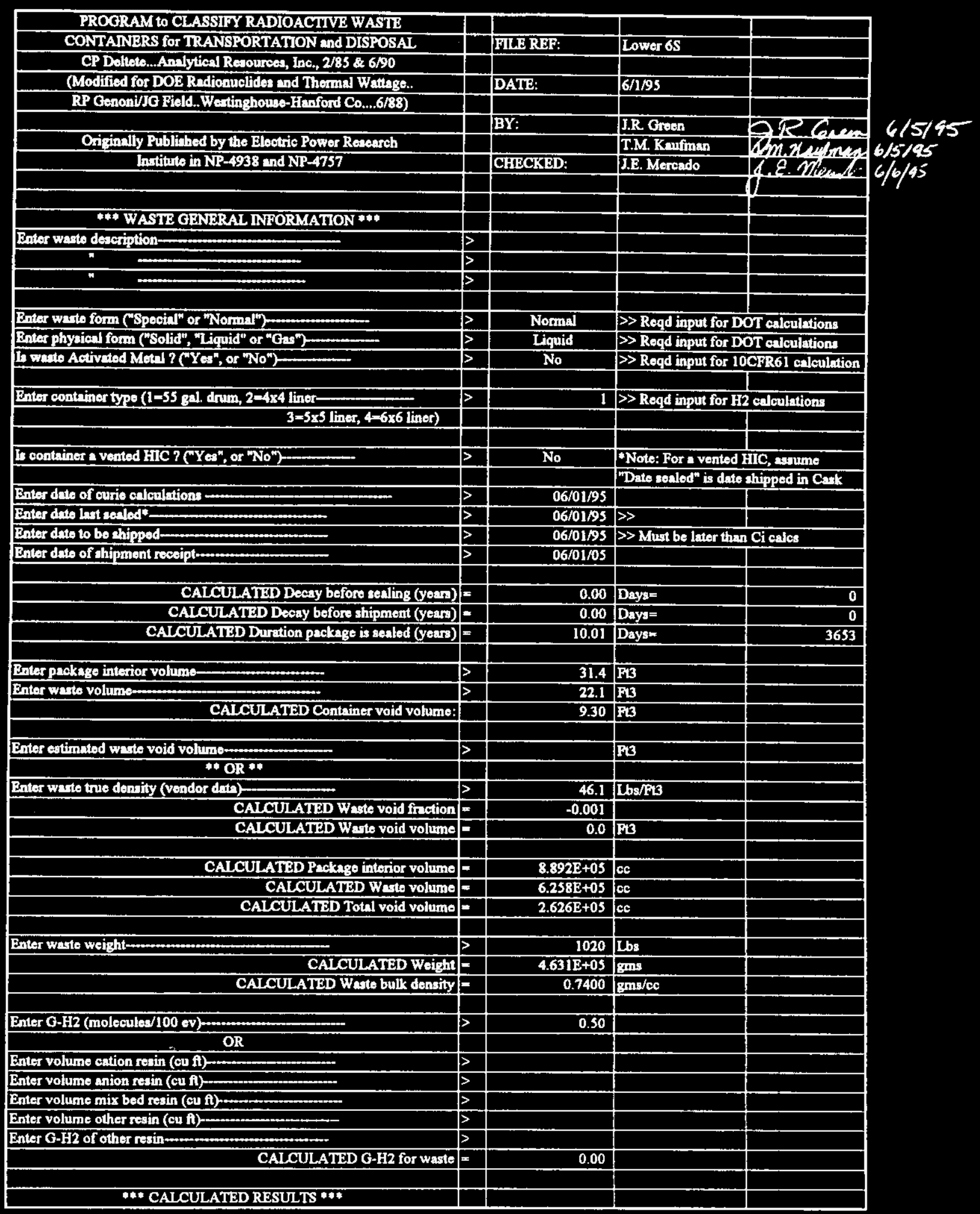




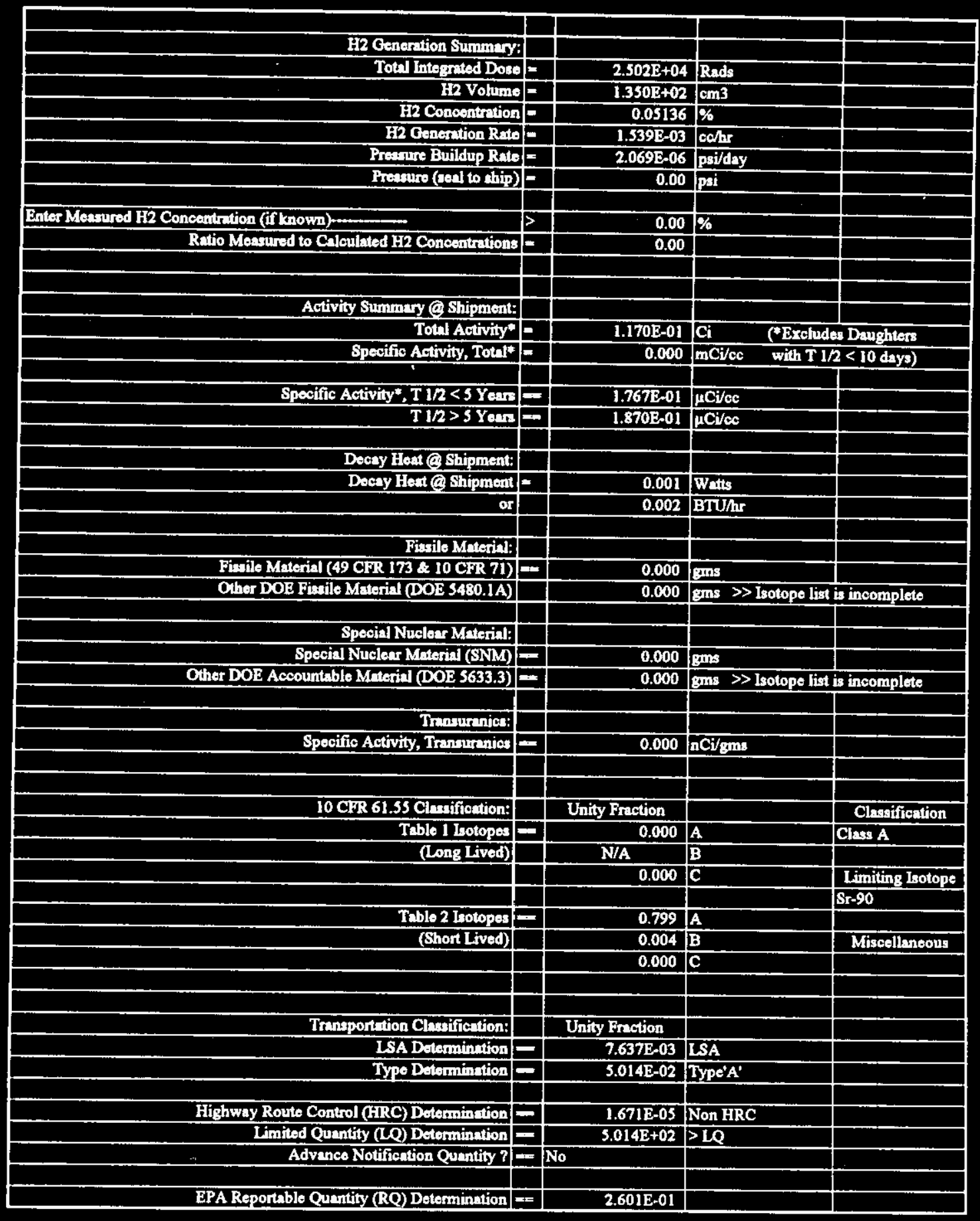


WHC-SD-TP-SEP-035 Rev. 1

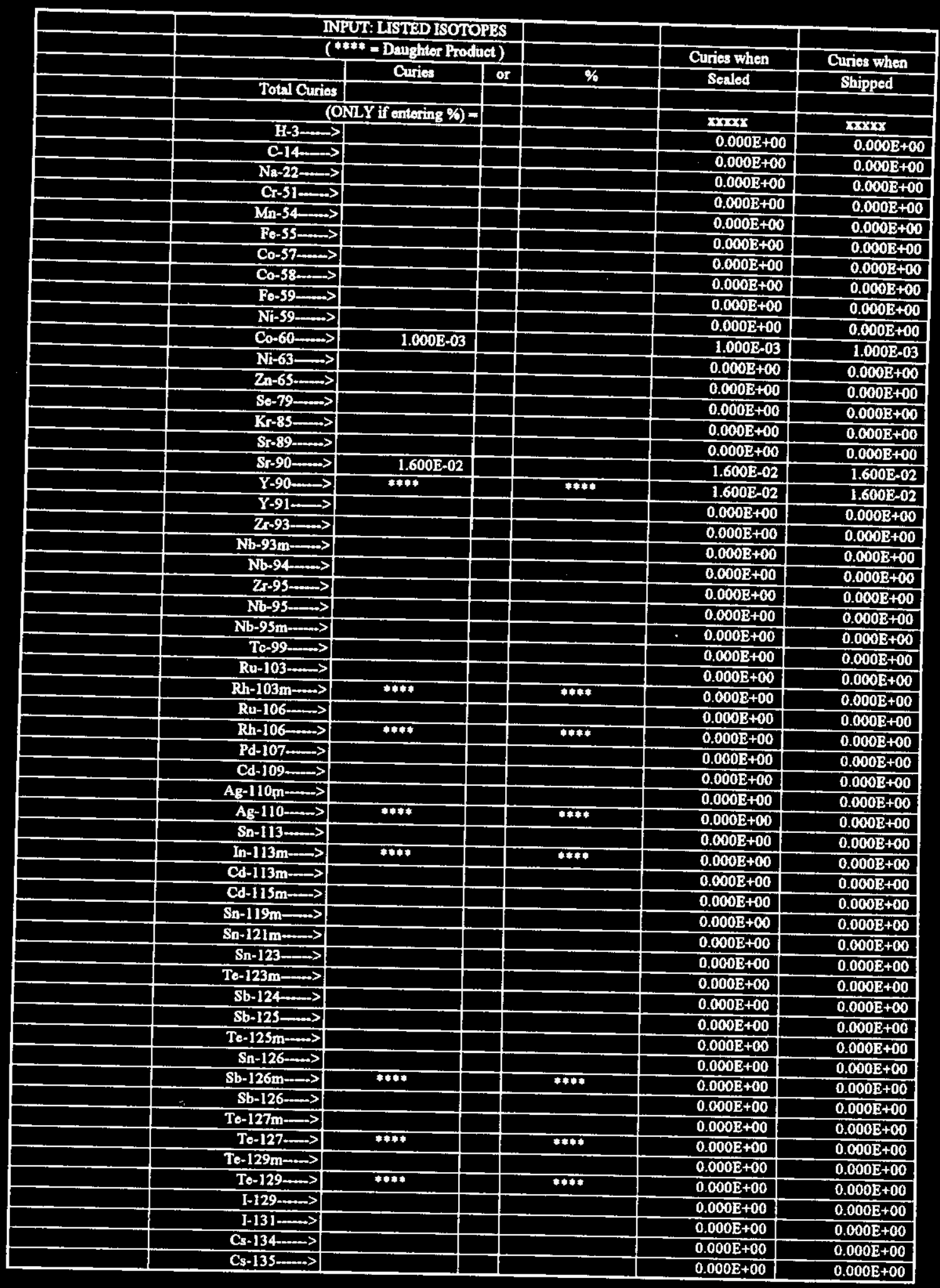


WHC-SD-TP-SEP-035 Rev. 1

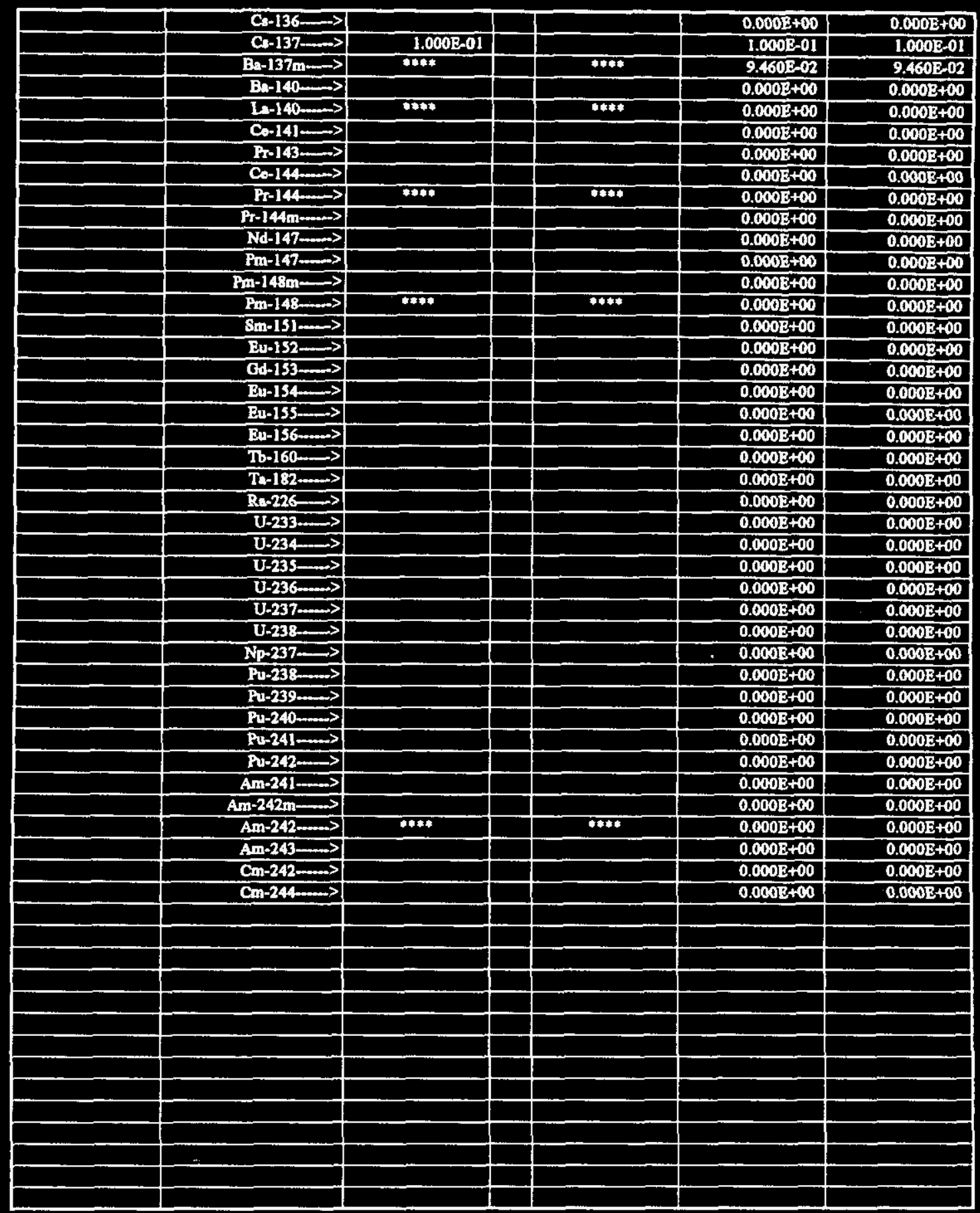




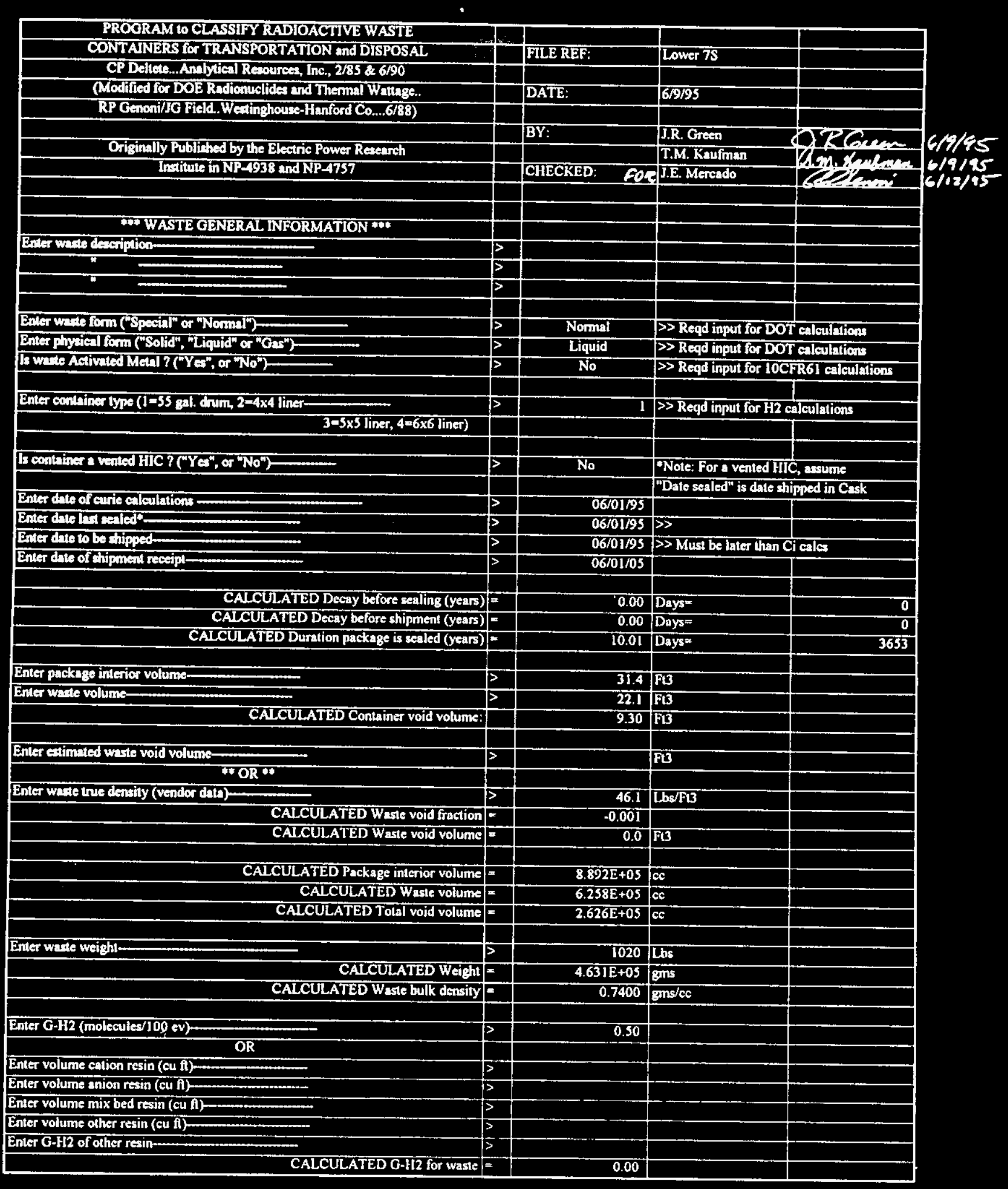




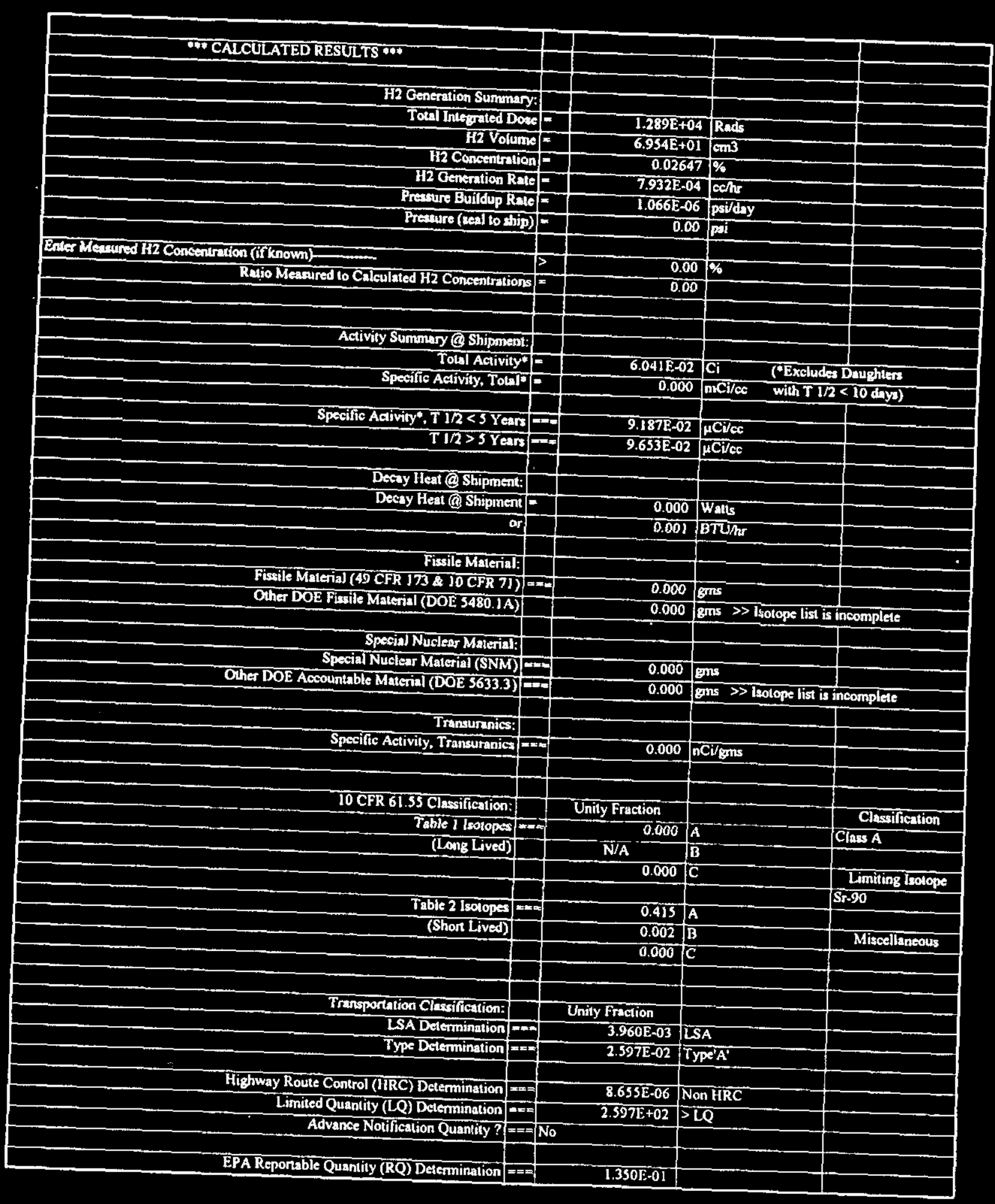




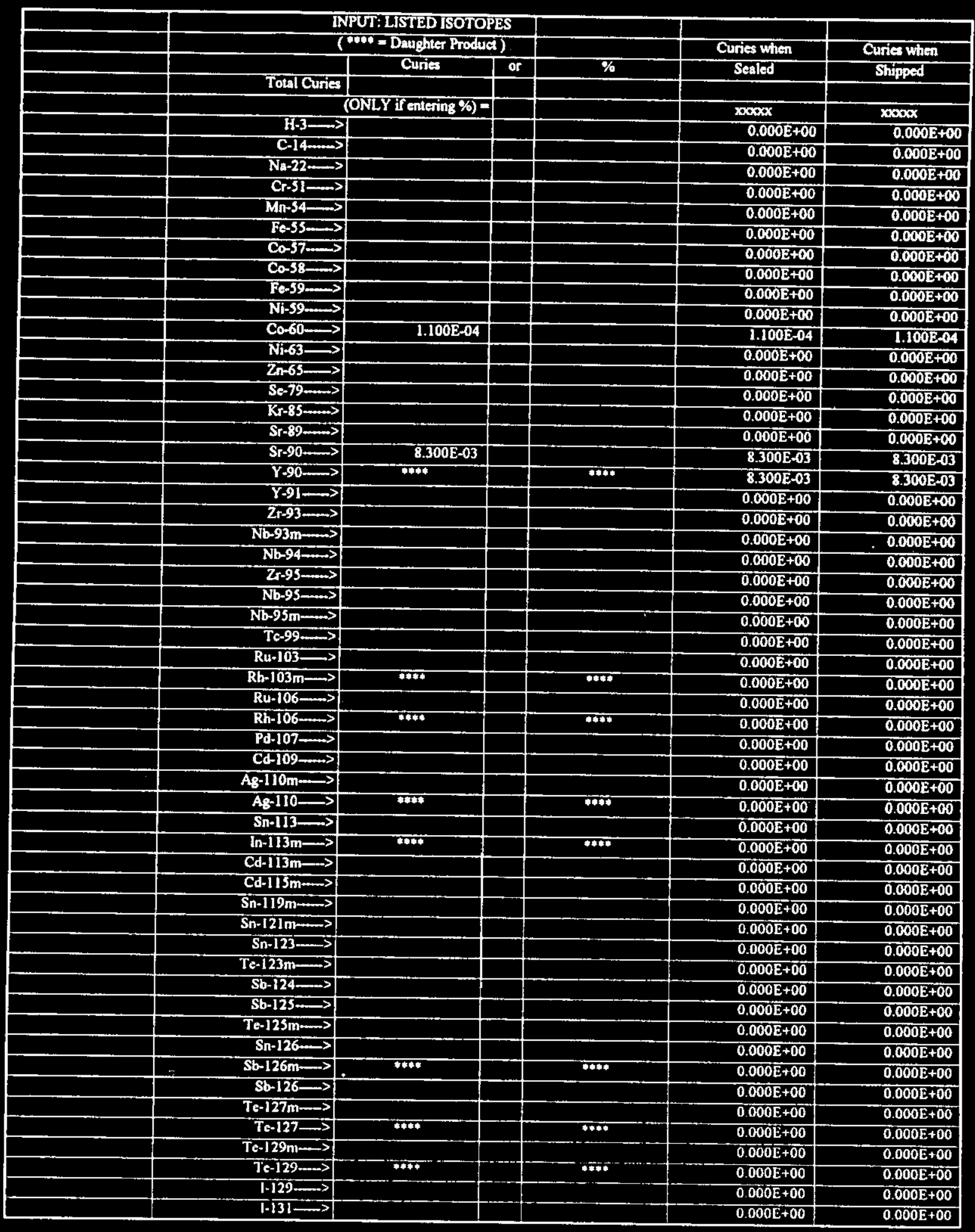


WHC-SD-TP-SEP-035 Rev. I

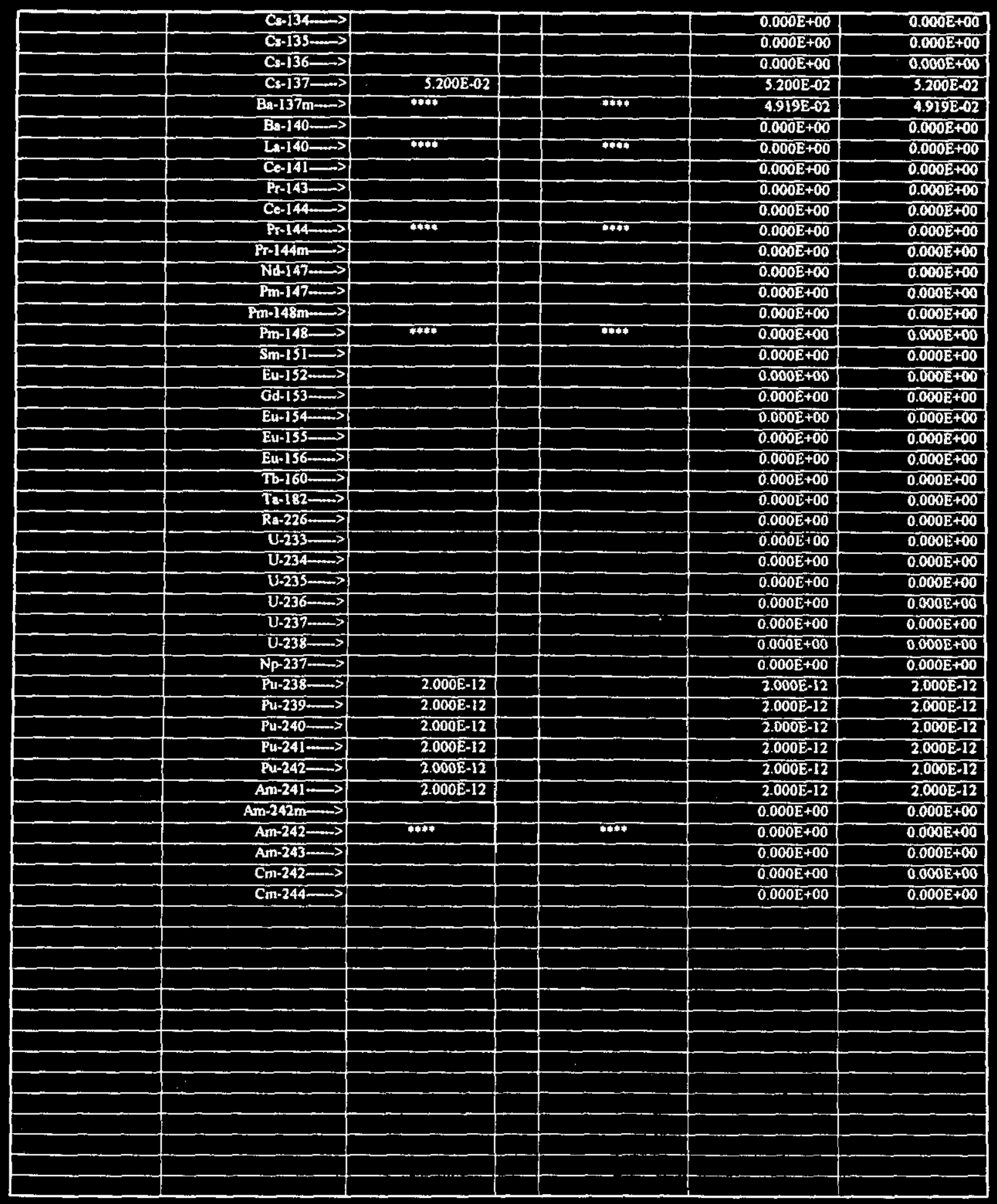


THIS PAGE INTENTONALLY LEFT BLANK 


\subsection{PACKAGE TIEDOWN SYSTEM EVALUATION}

\subsection{SYSTEM DESIGN}

The six nylon straps and fasteners used to tie down the metal boxes to the trailer shall meet the requirements of 49 CFR 393.102, "Tiedown Assemblies." Bracing will include I beams chained to the trailer, with one I beam on each of the four linear sides of the boxes for added stability to help prevent the load from shifting forward or backward or side to side on the trailer during transfer. However, credit for compliance to DOT Regulations will be taken primarily from the use of the six $12,000-16$-rated nylon straps.

\subsection{ATTACHMENTS AND RATINGS}

The number of tiedowns (i.e., nylon straps) is determined as follows:

Given: $N_{t}=($ Load) $(0.5) /$ Working Load Limit (WLL) of Straps

Box containing three columns:

24,900 Ib $\times 0.5 / 12.000=1.0375$ rounded up to 2 ( 2 straps used)

- Box containing four columns:

21,700 lb $\times 0.5 / 12,000=0.904$ rounded up to 1 (2 straps used)

Box containing five columns:

$$
8,2301 \mathrm{~b} \times 0.5 / 12,000=0.3429 \text { rounded up to } 1 \text { (2 straps used). }
$$

In conclusion, based on the wll of the straps and the number of straps used per box, the tiedown system used for transfer is acceptable and meets DOT requirements set forth in 49 CFR 393.102. 
THIS PAGE RNIENTIONALLY LEFT BLANK 


\subsection{REFERENCES}

10 CFR 71, "Energy," Code of Federal Regulations, as amended.

49 CFR 173, "Transportation," Code of Federal Regulations, Subpart I, and 178.350 .

49 CFR 393.102, "Tiedown Assemblics," Code of Federal Regulations, as amended.

Capital Industries, Inc., Container Certification Analysis for Part Number S 06000600 0104, Capital Industries, Inc., Seattle, Washington.

RL, 1994, Hanford Site Radiological Control Manual, HSRC-1, U.S. Department of Energy, Richland Operations office, Richland, Washington.

WHC, High-Integrity Container, 300 Year, HS-V-P-0036, Westinghouse Hanford Company, Richland, Washington. 
THIS PAGE INTENTIONALTY

LEFT BLANK 